This pioneering book opens up for us the great but largely unnoticed world of Christian writing in the Hindi language, India's majority language. Meticulous in its detailed attention to hitherto unnoticed literature, Hindi Christian Literature in Contemporary India maps subtly the interplay of language, politics, and culture today, while yet mindful of the long history of interactions between Hindus and Christians, India and the West. In this way, Peter-Dass uncovers for us a vital and enduring form of Christianity in India that will surprise those who know only Indian Christian theology in English, while shedding light too on Hindi culture more widely, and even Hinduism in the 21st century.

Francis X. Clooney, SJ, Parkman Professor of Divinity, Professor of Comparative Theology, Harvard University, USA

This ground-breaking and wide-ranging scholarly work on Hindi Christian literature provides a greatly overdue and much needed investigation into the articulation of Christian faith in North India, where over half a billion people speak Hindi. In a study that will have significant implications for the study of religion in general, Rakesh Peter-Dass deftly probes the complicated interconnections between language, social context, history and audience to provide an account of regional Christianity that is both innovative and persuasive.

Arun W. Jones, Dan and Lillian Hankey Associate Professor of World Evangelism, Emory University, USA

In the context of Hindu nationalists' longstanding proclivity to conflate Hindi, Hindu, and Hindustan (or India), and in an environment where the "Indianness" of Christianity is regularly contested, Christians' linguistic choices are always political. With lively and accessible prose that moves compellingly from one intriguing topic to another, Peter-Dass explores the political influences on and ramifications of literature produced intentionally and self-consciously in Hindi by India's Christians. Both a survey of this understudied genre and a critical analysis of its most salient obsessions, the volume introduces readers to authors like John Henry Anand, Benjamin Khan, Din Dayal, and Richard Howell, who, because of the inaccessibility of Hindi to many western (and even other Indian) scholars, have not received the attention they deserve. Pleasurably disorienting in its multilingual presentation, Hindi Christian Literature in Contemporary India offers a novel and important way of thinking about the relationship of Christianity and Indian culture.

Chad M. Bauman, Professor of Religion and Chair, Butler University, USA 
$\Longrightarrow$ Taylor \& Francis Taylor \& Francis Group http://taylorandfrancis.com 


\section{Hindi Christian Literature in Contemporary India}

This is the first academic study of Christian literature in Hindi and its role in the politics of language and religion in contemporary India. In public portrayals, Hindi has been the language of Hindus and Urdu the language of Muslims, but Christians have usually been associated with the English of the foreign 'West.' However, this book shows how Christian writers in India have adopted Hindi in order to promote a form of Christianity that can be seen as Indian, desi , and rooted in the religio-linguistic world of the Hindi belt.

Using different studies, the book demonstrates how Hindi Christian writing strategically presents Christianity as linguistically Hindi, culturally Indian, and theologically informed by other faiths. These works are written to sway public perceptions by promoting particular forms of citizenship in the context of fostering the use of Hindi. Examining the content and context of Christian attention to Hindi, it is shown to have been deployed as a political and cultural tool by Christians in India.

This book gives an important insight into the link between language and religion in India. As such, it will be of great interest to scholars of religion in India, world Christianity, religion, politics, and language, interreligious dialogue, religious studies and South Asian studies.

Rakesh Peter-Dass is Assistant Professor of Religion at Hope College, USA. His research and teaching focus on the intersections of religion with business, language, law, and politics. 


\section{Routledge Studies in Religion}

American Catholic Bishops and the Politics of Scandal Rhetoric of Authority

Meaghan O'Keefe

Celebrity Morals and the Loss of Religious Authority John Portmann

Reimagining God and Resacralisation

Alexa Blonner

Said Nursi and Science in Islam

Character Building through Nursi's Mana-i harfi

Necati Aydin

The Diversity of Nonreligion

Normativities and Contested Relations

Johannes Quack, Cora Schuh, and Susanne Kind

The Role of Religion in Gender-Based Violence, Immigration, and Human Rights

Edited by Mary Nyangweso and Jacob K. Olupona

Italian American Pentecostalism and the Struggle for Religious Identity Paul J. Palma

The Cultural Fusion of Sufi Islam

Alternative Paths to Mystical Faith

Sarwar Alam

Hindi Christian Literature in Contemporary India

Rakesh Peter-Dass

For more information about this series, please visit: www.routledge.com/ religion/series/SE0669 


\title{
Hindi Christian Literature in Contemporary India
}

\author{
Rakesh Peter-Dass
}

\author{
Routledge \\ 尊 Taylor \& Francis Group


First published 2019

by Routledge

2 Park Square, Milton Park, Abingdon, Oxon OX14 4RN

and by Routledge

52 Vanderbilt Avenue, New York, NY 10017

Routledge is an imprint of the Taylor \& Francis Group, an informa business

(C) 2019 Rakesh Peter-Dass

The right of Rakesh Peter-Dass to be identified as author of this work has been asserted by him in accordance with sections 77 and 78 of the Copyright, Designs and Patents Act 1988.

All rights reserved. No part of this book may be reprinted or reproduced or utilised in any form or by any electronic, mechanical, or other means, now known or hereafter invented, including photocopying and recording, or in any information storage or retrieval system, without permission in writing from the publishers.

Trademark notice: Product or corporate names may be trademarks or registered trademarks, and are used only for identification and explanation without intent to infringe.

British Library Cataloguing-in-Publication Data

A catalogue record for this book is available from the British Library

Library of Congress Cataloging-in-Publication Data

A catalog record for this book has been requested

ISBN: 978-0-367-32223-6 (hbk)

ISBN: 978-0-367-33063-7 (ebk)

Typeset in Sabon

by Apex CoVantage, LLC 
For Sharon 
$\Longrightarrow$ Taylor \& Francis Taylor \& Francis Group http://taylorandfrancis.com 


\section{Contents}

Acknowledgments $\quad x$

1 Politics of religion 1

2 The making of a genre 47

3 Linguistic choices $\quad 79$

4 Shaping identity 105

5 Christians in India 147

6 Message matters $\quad 190$

$\begin{array}{ll}\text { Index } & 221\end{array}$ 


\section{Acknowledgments}

Many people and groups helped this book. Their support has been invaluable, and though I bear sole responsibility for the final manuscript, their encouragement runs deep and wide.

Insightful conversations with advisors and colleagues have enriched this study. In this regard, Professor Francis X. Clooney, S.J., deserves a particular word of thanks. This book would be impossible without his early and consistent support, thoughtful critique, and pastoral advice. Frank mentored a voyage into the study of new and unused sources. I am also grateful to key advisors who read the manuscript in full or part and guided this project with constructive insights: Professors Susan Abraham, Ali S. Asani, Arun W. Jones, Charles M. Stang, and Ronald F. Thiemann. This study was collaborative and the following people deserve special recognition for their substantial contributions: Rev. Dr. John H. Anand (my primary collaborator in India), Emily Burgoyne (my primary advisor at Angus Library, Oxford), Rev. Dr. Ashis Amos, Daniel Manorath (who travelled to Lucknow to gather sources on my behalf), and Ram Ikbal Rai (who made research trips across central and north India possible). John $\mathrm{H}$. Anand, the long-serving editor of Hindi Theological Literature Committee, deserves special credit. He spent countless hours educating me on Hindi Christian history, endured endless rounds of questions, sent me hundreds of Hindi Christian materials on request, and introduced me to Hindi Christian writers.

The ideas in this book were presented at various venues. I am grateful for the feedback I received from participants of academic gatherings at Harvard University, Harvard Divinity School, St. Mary's Church at the University of Oxford, Asian Theological Summer Institute at the Lutheran Theological Seminary in Philadelphia, New England and Maritime Region of the American Academy of Religion, Boston College, Wabash Center for Teaching and Learning in Theology and Religion, American Academy Religion, Thirteenth Assembly of the World Council of Churches, and Hindi Theological Literature Committee.

My research required considerable support from institutions. I am grateful for their generosity. The South Asia Institute at Harvard supported two long research trips to India. Harvard Divinity School's Dissertation Fellowship 
and Travel Grant supported a third research trip. The Selva J. Raj Endowed International Dissertation Research Fellowship of the American Academy of Religion and the Educational Grant Program of the Evangelical Lutheran Church in America offered the time to complete the project and use the missionary archives of Angus Library at the University of Oxford. In India, two institutions deserve special recognition. The Hindi Theological Literature Committee, based in Jabalpur, served as the primary source of Hindi Christian texts and history. The Indian Society for Promoting Christian Knowledge partnered in Delhi. In concert, these publishers provided research personnel and timely guidance. Other publishers also supported this study, and I am thankful to the International Journal of Hindu Studies and Nidan: International Journal for Indian Studies for their permission to republish parts of their works in chapters 1 and 3. Finally, I am thankful to my editors and anonymous reviewers at Taylor \& Francis-Routledge. Their feedback has sharpened the book.

Rakesh Peter-Dass

May 2019

Holland, Michigan 
$\Longrightarrow$ Taylor \& Francis Taylor \& Francis Group http://taylorandfrancis.com 


\section{Politics of religion}

\section{Hindi Christian politics}

On a Sunday morning 225 years ago, William Carey walked into a local market in Bengal and started speaking to a congregation of Muslims. ${ }^{1}$ It was the winter of 1794 and Manicktullo B $\bar{a} z \bar{a} r$ was busy. Carey had just arrived in India - in November 1793, to be precise. At the market that day, the Baptist missionary was accompanied by his local assistant (mumsín). Local clerks played an important role in the work of missionaries in India. Carey's Journal is replete with references to his 'Munshi.' The munshi helped him learn the vernacular, translate scripture, preach to locals, teach in school, and run the press. Carey could not speak proper Bengali and was unable to preach for months after he reached Bengal. The munshi translated and spoke for him most days. As it turned out, Carey would be glad his 'Munshi' was with him. ${ }^{2}$

Carey was happy with the turnout that day. "Our Congregation," he wrote, "consisted principally of Mahometans, and has increased every Lord's Day; they are very inquisitive; and we have addressed them upon the subject of the Gospel with the greatest freedom." ${ }^{3}$ It is unclear whether "congregation" referred to a group of Christian converts or interested Muslims or some combination thereof. At the very least, the Journal makes it clear that Carey had found an eager audience that was growing every Sunday in the $b \bar{a} z \bar{a} r$. Various topics were discussed but none generated more interest than two: Which was better, the Quran or the Gospels? Who was greater: Mohammed or Jesus? The debate on the first topic was vigorous. Each side spoke freely. Carey argued most Muslims could not read Arabic. If you could not read Arabic, he asked, how could you follow the Quran? Also, if you could not read it, how could you know if it was true? The 'Mahomedans' countered by claiming they had learned Quranic instructions and one of them had even read it in Arabic. Then, in their turn, the Muslims pressed. "The Quran was sent to confirm the Words of Scripture" because "Jews, and Christians had corrupted the Bible, which was the reason why God made the revelation by Mahomet." The Quran was clearly an improvement on the Bible. So why settle for second best? 


\section{Politics of religion}

The conversation on who was better was equally lively. Carey posed the question: Who was better, Mohammed or Jesus? The Muslims replied, Carey notes, "Mahomet was the Friend of God, but Esau, by whom they mean Jesus, was the Spirit of God." A friend was more important than a spirit. One could relate to a friend, spend time with a friend, have a personal relationship with a friend. What could the spirit do? Carey fell silent, it seems, for his clerk piped up. But who is higher, Munshi countered, your friend or your soul or spirit? Carey thought Munshi was clever - "shrewd," he writes - but the Muslims were not impressed. Carey does not record the Muslims' response to Munshi but Carey's notes suggest the Muslims left unconvinced of the superiority of Christianity. "All this [back and forth] they bore with good temper; but What effect it may have time must determine." The interplay between listeners and preachers was complicated. Christians preached and the Muslims talked back. The Muslims countered and the Christians talked back. Carey records numerous such encounters in his journals. The encounters were open-ended - at least, Carey logs them that way. Discourses on religious conversions in contemporary India portray a different interplay of voices. The next story from 1993 illustrates the difference. Two centuries after Carey's encounter, Indian Christians find themselves in a situation where states and governments have found it necessary to curb the perceived threat of Christian evangelism to social order in India. Carey's encounter with Muslims does not represent the standard encounter between missionaries and others. In some cases, the encounter was fruitful - in others, hostile. I have employed the Muslims-Carey chat-inthe-market ( $b \bar{a} z \bar{a} r$ b $\bar{a} t c \bar{t} t)$ to contrast it with public perceptions of Christian evangelism in contemporary India.

On March 12, 1993, two hundred years after the bāzār bātcìt, a group of Christian leaders walked into a meeting with the governor of Andhra Pradesh. Governor Krishan Kant had called the meeting. Bishop Franklin Jonathan was in attendance and recorded the exchange. The Christians met Kant for more than an hour, and Jonathan was impressed. Kant was "a good scholar, top-class politician and a political leader desirous of national unity and communal harmony." Kant had something specific on his mind. He wanted to talk about evangelism. He wanted to and proceeded to criticize Christian mission. He doubted Christian motives and questioned their actions. Kant praised Christians as learned and enlightened but was adamant in alleging that evangelism was a social problem. For Kant, propagating religion was not an invitation to a conversation but a slippery slope to discord. It needed to stop. The Christian community and Christian leaders are "most enlightened," Kant felt, but it was the governor's "request" (agrah) that all forms of evangelization "be voluntarily stopped for at least fifty years." ${ }^{5}$

Kant made a request. It was not a demand. Jonathan took pains to note this. Kant was a state official in secular India and could hardly demand that Christians in India voluntarily self-curtail their constitutional right to 
profess and propagate religion. Kant did not say his ask was a request. Jonathan described it as such. One wonders whether Jonathan was being diplomatic in print. Noticeably, Jonathan does not print the Christians' response. Did they talk back? Did they refuse the 'request'? Did they agree to consider it? Did they offer any response, then or later, to the governor? It is clear that Kant's request did generate some reflection on Jonathan's part. "What is the meaning," Jonathan wrote, "of evangelism? Is it to share the love of God with others?"6 "Have we," Jonathan wondered, "sent the wrong signal to those who are outside the church?" Jonathan was sympathetic to Kant. Yet his response to Kant is absent from his public report. It is unclear whether the Christian leaders did much after the meeting or whether Christian communities paid any heed to Kant's ask.

Comparing the encounters is revelatory. Contemporary perceptions of Christian activities have focused on evangelistic practices by Christians. While the social footprint of Christian churches in India - through their many hospitals, schools, colleges, orphanages, and charities - garners little public attention, conversions and evangelistic practices have come to occupy a primary place in public perceptions of Indian Christians. State governments and lawmakers have felt increasingly motivated to intervene in such practices in order to 'protect' easily-swayed 'Hindus' from converting. Studies have traced the relevance of caste context behind such motivations. ${ }^{8}$ Nevertheless, in contemporary narratives of Christian evangelism the agency to refuse Christian claims seems to have disappeared. According to accounts of Hindu nationalists, 'naïve and easily-swayed Hindus' need to be protected from the aggression of Christian evangelists. Underlining the opposition to Christian conversions in India is the perception that one cannot be both a loyal Christian and an Indian. This perception is being fostered by a pair of complementary forces in contemporary India: Hindu nationalism and Hindi nationalism.

Hindu nationalism and Hindi nationalism are complementary ideas. A Hindu is original to India and India is Hindu. A Christian or Muslim is a foreigner and not Indian. Allegiance to one group (India) cannot overlap with allegiance to another group (Christianity, Islam). Aligning with both identities can only divide an Indian's loyalty. Hindu nationalism argues that pitting one identity against the other is the outcome of confusion on what it means to be 'Indian.' A central feature of Hindutva has been portrayals of Muslims as a "community outside the 'national mainstream" " and intent on undermining "Indian/Hindu culture and civilization." A 'true Indian' is anyone who recognizes India, the land of Hindus, as her geographic fatherland and cultural motherland. 'Indian' and 'Hindu' are synonymous, and for Hindu nationalists, as Richard G. Fox puts it, a bharatiya ('of India') is a 'Hindian.' As such, attributes like Hindu, Christian, Muslim, Sikh, Tamil, and Dravidian are sectarian identities that should never be confused with and empowered over an Indian's essential identity, which is Hindian. ${ }^{10}$ The third attribute of an Indian is loyalty to Hindi. This is the central claim of 


\section{Politics of religion}

Hindi nationalists. Hence, advocates for the national primacy of Hindi in India made claims regarding the foreignness of Urdu and Muslims that echoed the claims made by Hindu nationalists.

Both movements - Hindu nationalism and Hindi nationalism - matured around the same time, the quarter century preceding 1947. Both movements had similar demographic attributes. Hindu nationalism drew support from Hindu, urban, young, lower-middle class, and 'forward caste' groups like Brahmans, Kayasths, Khatris and Baniyas (medium- and small-scale merchants) ${ }^{11}$ Hindi nationalists drew support from Hindus, urban, middle class, educated, forward castes like Brahmans, Kayasths, Bhumihars (land-holders), Rajputs, and Baniya groups like Agarwals and Vaishyas. ${ }^{12}$ Both movements complemented each other. "Hindi, Hindu, Hindustan," or "Hindi, Hindu, India," the slogan went. ${ }^{13}$ The movement to Hinduize India had a willing and enthusiastic partner in the movement to Hinduize Hindi and Hindi-ize India. ${ }^{14}$ Finally, both movements had their geographic center in north India, further cementing the fusion of language and religion as a central attribute of the national identity under construction by the religious group dominant in the corridors of political power in independent India.

In contemporary India, religions have languages. This idea has been expressed in certain ways. Hindi is the language of Hindus, Urdu is the language of Muslims, and Christians have associated most frequently with English, the language of the 'West.' In public imaginations, English remains the language of India's colonizers (more on this later). In contemporary India, English is ascendant due to its status as the primary language of global advantage. ${ }^{15}$ Yet English remains a 'foreign' language. As Christopher King has noted, Hindi has become synonymous with Hindu, and Urdu has become synonymous with Islam (more on this later). However, to the fusion of language and religion another type of claim is linked. These arguments are related to autochthonicity. And the lingo-religious argument described earlier morphs into a linguistic-religious-geographic moniker. Hindi is not merely the language of Hindus in India but rather is the language of the autochthonous Hindus of India. Urdu is the language not merely of Muslims of India but rather of Islamic invaders of India. Similarly, the argument goes, English is the language Christians in India have received and adopted from their Western and colonizing predecessors. When Urdu and English are portrayed as foreign and intruders, the religions linked with them are portrayed as foreign and intruders as well. Hindi and Hindu nationalists are not the only agents of such conflations. The linguistic organization of pre- and post-independence India strengthened the connection of ethnicity and religion with language and political power. The movement for Indian independence promoted Hindustani as the national language and from the process Hindi in the Devanagari script emerged as the national language. The emergence of Hindi in the nation's story, though controversial, continues to shape ideas regarding nationality and Indianness in terms of Hindi idioms. 
Shaped by a sense of the Hindu-Hindi-ness of the nation, Christian writers in India have promoted Hindi as the proper language of Indian Christians in order to promote Christians as Indian, deśî, and rooted in the linguistic world of Hindi. Hindi Christian works counter the politics of religion and language prevalent in independent India. In light of the widespread perception of Christians as aggressive evangelists, followers of a foreign faith, and culturally not Indian, Hindi Christian works present a religion that is linguistically Hindi, culturally Indian, and theologically open to Hindu and Muslim ideas. Works of Hindi Christian prose and poetry convey a certain type of religious identity that is intentionally Hindi, Indian, and political. In this book, I explain why and how this identity has taken shape and manifests itself today. Hindi Christian works are political in nature, aim to sway public perceptions, promote particular forms of citizenship, and do all this in the context of fostering the use of Hindi. This attention to language takes different forms. It is shaped by the foundational idea that religion and language are intertwined in India. It is essential to recognize the place of languages in India's story and the relation of languages to ethnoreligious identities in India in order to grasp the impulses surging through Hindi Christian arguments. As the book proceeds, I add details to the story of languages and religions in India.

India's religious history is a story of languages. English, Hindi, Sanskrit, Tamil, and Urdu have influenced the politics of religion in India. Dravidians used Tamil and other languages to develop distinct religious ideas. Sanskrit was deployed to manage the political power of certain social groups. Hindi and Urdu were shaped by relations between Muslims and Hindus in classical India and continue to do so in India today. Linguistic cultures influenced each other too. Tamil influenced Sanskrit and Sanskrit influenced Tamil. Urdu influenced Hindi and Hindi influenced Urdu. English influenced Hindi, and English has been influenced by many other Indian languages. Further, India's religious history is a story of multilingualism. In Vedic horse sacrifices, for instance, different groups speak different languages and the four priests are supposed to call the sacrificial horse with four different names. ${ }^{16}$ Emperor Ashoka had the empire's values inscribed in Pali and other languages spoken throughout the empire. Sanskrit and Urdu encountered each other in Mughal courts. ${ }^{17}$ Hindi and Urdu were co-languages of Muslim and Hindu literature till the politics of the nineteenth century intervened. ${ }^{18}$

The politics of religion and of language have shaped each other. Christian deployments of Hindi fit this pattern. But a lacuna haunts our understanding of religion and language in contemporary India. Hindi Christian sources are not the subject of the academic study of religion. A few scholars study these sources. ${ }^{19}$ Hindi sources are part of literary history. ${ }^{20}$ Hindi literature is part of scholarship beyond South Asia in studies of devotionals, poems, and novels. ${ }^{21}$ Indian Christians use many languages in addition to Hindi. Recently published sources of Indian Christian literature would reveal sources mostly from southern India (for instance, in Malayalam and 
Tamil) and in English. Recent research has examined vernacular Christianity in Marathi. ${ }^{22}$ However, Hindi Christian sources are not the subject of current studies of language and religion in India. I correct this lacuna and present a study of Christian materials in 'modern standard Hindi.' These materials cover hymns, poems, guidebooks, theology-ethics, stories, and translation choices. Or, in the vocabulary of Hindi Christian materials, I examine git-sangìt (songs), bhajan (hymns), katha (stories, or narratives), kavitā (poetry), dharmavijūān (theology), nìtis̄āstr (ethics), àrādhănā (worship), gāid or sandarśikà (guidebooks), țìkā-țippaṇi (scriptural commentary), darśan (philosophy), and itihās (history). ${ }^{23}$ Hindi Christian sources are attuned to the politics of language and religion in India. I show why this is the case, describe the forms in which this attention is manifested, examine the nature of Christian attention to Hindi, and explain the political claims embedded in Hindi Christian ideas.

Attention to the politics of language and religion is evident in three distinct, overlapping, and ongoing debates in Hindi Christian works. These debates are the subjects of chapters 3-5. Should Christians in India use Hindi, and if they should, how should they use Hindi in ways distinct from Hindu ideas and Western ideas? This debate, which is the focus of chapter 3, has played out in discussions on translation choices when trying to express Christian ideas in Hindi. A parallel debate has played out over media representations of Indian Christians. This is the focus of chapter 4. The question of representation emerged as a topic of discussion particularly after state television (Doordarshan) started airing religious programs in the 1980s. The third debate, which is the focus of chapter 5 , is concerned with the ways in which Christians must act in a multifaith society such as is found in India. Commentaries on the subject of national participation explore proper Christian notions on citizenship, relation with people of other faiths, discipleship, and identity in India. By 'Hindi Christian sources' I mean a corpus of materials in post-1940 central and north India written and published in modern standard Hindi. As a language of religious communities, Hindi is not exclusively Christian in purpose. However, the book studies Protestant Hindi Christian materials available in India through both 'mainline' and independent publishers.

\section{What is Hindi Christian?}

I deal with Hindi Christian works. Such a claim raises certain questions. First, what is 'Hindi,' as I use the term? Second, is 'Hindi Christian' a justifiable descriptor? Finally, what does it mean to call a Christian work a Hindi Christian work? What makes a Christian work particularly Hindi? The rest of this section answers the first question. The next section answers the second question. The second chapter answers the third question, but I can preview the second chapter here with brief comments. It is the essential attribute of a Hindi Christian work that it does not use Hindi merely 
because that happens to be the local language or the popular language in the region. Rather, a Hindi Christian work includes reflections on why Hindi should be used. It comments on the effect of using Hindi on the content of the work. It chooses to use Hindi specifically to serve an unserved audience and draws discriminatingly from the world of Hindi idioms. In each aspect of its work, it asks how Hindi influences the Christian idea under examination. In doing so, it grounds Christian ideas in Hindi rather than simply expressing Christian ideas in Hindi. As such, theology, ethics, poetry, liturgy, and other aspects of Christian life are given new terms and a network of ideas at home in the religious worldviews of Hindi-speaking India. I will say more on this in the second and third chapters. But for now, I return to the first question. What do I mean by 'Hindi' in the term 'Hindi Christian'?

By 'Hindi,' I mean 'modern, standard Hindi.' The emergence of modern, standard Hindi can be traced to Middle Indo-Aryan language forms. ${ }^{24}$ What is 'standard' about 'modern, standard Hindi' is its geographic use and standardized form (at least its written form, though variations in pronunciation exist). It has a geographic reach. It is spoken by the people in particular regions and has the loyalty of its speakers. It is easy to use and is a popular medium in which local people communicate. In this sense, Hindi is a regional language of India. As a matter of practice, all Indian languages are regional since no language is the primary language used by all Indians. Uday Narayan Tiwari, an influential biographer of Hindi, has explained the historic status of Hindi: a " "regional language' is the name for peoples' language" and "the language that occupied this position in a particular time and place was known by this designation." ${ }^{25}$ From 600-1200 CE, developed forms of Middle Indo-Aryan language occupied this position. By the thirteenth and fourteenth centuries, Modern Aryan languages had become the local or regional languages. Among Indian languages, Hindi was the language of the middle part of the country, and modern forms of literary Hindi and Urdu can be traced to the Khaṛi Bolī ("standing speech" or "stand[ard] speech") form of western Hindi spoken near Meerat and Bijnor in modernday Uttar Pradesh. ${ }^{26}$ Spoken together, Hindi-Urdu was called Hindustani. As a descriptive term, 'Hindustani' itself was the invention of John Gilchrist, a colonial linguist, who coined the term in eighteenth century to 'unify' distinct languages spoken in north India. Hindustani, in Gilchrist's construction, was a single language with three dialects differentiated by the extent to which they used Sanskrit, Persian, and Arabic. This 'Hindustani' was eventually conflated with Urdu and given status as the language of official business during the Raj in large parts of northern India. ${ }^{27}$

Hindi-Urdu share a "virtually identical" grammar and core vocabulary with differences in usage and terminology so minor that it is not possible to clearly tell whether someone is speaking 'Hindi' or 'Urdu. ${ }^{28}$ Suniti Chatterji's influential history of Indo-Aryan languages divides the development of Indian languages into three periods: Old Indo-Aryan (or Vedic Sanskrit) from 1500 вСе to 500 вСЕ; Middle Indo-Aryan (or Prākrit) from 500 вСЕ 


\section{Politics of religion}

to $1000 \mathrm{CE}$; and New Indo-Aryan from $1000 \mathrm{CE}$ onward. ${ }^{29}$ Colin Masica adapts Chatterji's history and proposes slightly different time-periods: 1500 вСе-600 вСЕ for Old Indo-Aryan; 600 вСЕ-1000 CE for Middle IndoAryan; and $1000 \mathrm{CE}$ onward for New Indo-Aryan. ${ }^{30}$ Hindi-Urdu belong to the New Indo-Aryan family of languages.

Hindi or Hindustani appeared at the tail end of a long history and it took 11 centuries, roughly from $1100 \mathrm{CE}$ to $1800 \mathrm{CE}$, to develop. For the linguistic genealogy of Hindi, Chatterji's Indo-Aryan and Hindi, published 76 years ago, is still the standard account. ${ }^{31}$ The story of Hindi begins "somewhere in Europe" where a Primitive Indo-European language was spoken in its undivided state by a group of people philologists have called Wiros, the Primitive Indo-European word for 'man.' The Wiros did not develop a material culture of any high order. What they did leave behind was a language and a well-organized society. Their society was patriarchal and made up of a collection of clan groups. They showed respect for women and developed a religion where the unseen forces of nature (viewed as God or Gods) were characterized as beneficial rather than harmful. God or Gods lived in heaven above, as distinct from humans, who lived on earth. Gods were not anthropomorphic beings. Conjectures about this people and their society have, as a result, been the province of linguistic paleontology rather than of archeology. Half-nomadic and half-settled, the Wiros travelled and took their language and social organization with them. One group of Wiros left the homeland to travel south. These Indo-Iranians or Aryans reached northern Mesopotamia by 2000 BCE.

Indo-Iranian or Aryan culture and religion were the predecessors of both Vedic Indians and pre-Zoroastrian Iranians. Once they arrived in India after 1500 все, the Aryans encountered non-Aryan cultures in the Indus Valley and Dravidian peoples. The Aryans were not indigenous to India. Indus Valley artifacts do not include Aryan motifs. As an instance, horses, popular in Aryan culture, are absent in Valley seals, pottery, and other leftovers. Aryans slowly migrated from Eastern Iran into Punjab in Western India. Archeological and linguistic evidence suggests the arrival of the Aryans was not in the form of a sudden invasion but rather in the form of a slow migration, which eventually led to the development of culture that mixed Aryan and Dravidian elements. There is evidence that the Indus Valley script was not a proto-Aryan script but belongs to the Dravidian group of languages. ${ }^{32}$ The encounter between the Aryans and non-Aryan people profoundly changed the Aryans and their language. Aryan or Indo-Iranian language changed into Indo-Aryan, represented in its developed form in the Rig Veda. The Indian Aryans laid the foundation of the Vedic culture. The language of the Indo-Aryans took two forms: a spoken form, Prākrit, and a cultured, written form, Sanskrit.

From 1000 все onward, Sanskrit became the language of religion and higher intellectual life in upper India and the forebearer of Hindu culture. By 600 вСE, Prākrit and Sanskrit had begun to spread south into the Deccan 
and mingled with well-established groups of Dravidian speakers, whose native speech was too fixed to adopt Aryan elements. Yet, by this point the Aryan language had superseded India's non-Aryan languages and was dominant from Afghan to Bengal. The grammar of Sanskrit was fixed by Pānini around the fifth century вСE. By 500 вСE, Vedic culture and Sanskrit had fully incorporated (upper) Indian culture. Prākrit developed unimpeded along with Sanskrit, and where Sanskrit was standardized more or less from the fifth century BCE, Prākrit (the spoken dialects of Aryan India) differed considerably. One such Prākrit to gain prominence in northern India was Western Apabhramśa, which had established itself as the lingua franca in upper India by the tenth century CE.

Western Apabhramśa is the immediate predecessor of both Braj-bhāsāa (a modified form of Western Apabhramśa) and Hindustani. When the Turks and Iranians (with their Persian language) conquered north India in the tenth and eleventh centuries CE, Western Apabhramśa and its local dialects were dominant in the region. It is in the history of Turkish and Iranian rulers of India that the first reference to 'Hindi' appears as a language distinct from Prākrit and Sanskrit. The Tabaqāt-i-Akbarī of 1022 CE reports a poem by the Rajput king of Kalanjar "in the Hindū tongue." This tongue's first name was simply Hindī or Hindwi (Hindawī), which meant the language of Hind or India or 'of the Hindus' (the 'Hindus' being a geographic designation, and not a religious one, for the people who lived beyond the Indus river). As Chatterji notes, however, this early 'Hindī' was most likely not Braj-bhāṣā or later Hindustani. We have no Hindi or Hindustani before the thirteenth and fourteenth centuries CE. However, after the Muslim ruling house had been established at Delhi in the sixteenth century, the common language of the masses in northern India at the time, Braj-bhāșā, started to gain prominence. Braj-bhāṣā was written in the Devanagari script. Even as the language became the medium of courts and of culture and poetry, it remained a specialized literary dialect rather than a popular, colloquial one. That role was assumed by the language popular in the markets of Delhi, a dialect of Western Hindi. This vernacular was called Hindi. Its other name that arose later in the seventeenth century - was Zabān-e-Urdiu, or 'language of the camp.' 'Urdu' is a Persianized spelling of a Turkish word that means tent, dwelling, or encampment and identified the spoken language popular in the Delhi camps of the Muslim rulers. Urdu developed a Perso-Arabic vocabulary and an Arabic script. This form of Hindi - with its Perso-Arabic vocabulary and Arabic script - had become the language of Muslim nobility and religious men in the seventeenth and eighteenth centuries.

Two forms of Hindi or Hindustani were developing in the seventeenth and eighteenth centuries: the Hindustani of Delhi, and a Deccan dialect of Hindustani popular among north Indian Muslims settled in the Deccan. It was the north Indian Muslims in the Deccan who set the stage for the literary separation between Hindustani or proper Hindi and Braj-bhāṣā. Trying to assimilate among their Hindu neighbors, Deccan North Indian 
Muslims adopted the Delhi language they brought with them and started writing it in the Persian script, which was still the language of the Muslim power centers in Delhi. North Indian Hindi speakers adopted this Deccan practice and started using Delhi Hindi in its Persianized form. By the beginning of the eighteenth century, this Persianized Delhi Hindi acquired a new name: Hindōstānī. By 1970, the name was accepted by north Indians and Indianized by the Hindus as Hindūsthānī. However, north Indian Hindus of the Eastern Provinces continued their attention to Delhi Hindi in its Braj-bhāṣā form.

Toward the end of the eighteenth century, Braj-bhāṣā Hindi came to acquire the name Khari Bolī (or "standing language") as distinct from dialects like Braj-bhāṣā and Awadhī proper, which were designated 'fallen languages' or Parī Bolì. Hindustani or Hindi therefore emerged in the eighteenth century in two forms: High Hindi (Khaṛī Bolī Hindi in the Devanagari script) and Urdu (Persianized Hindi in the Arabic script). This modern Hindi was common to both Hindus and Muslims. Two forms of the same language, Nagarai Hindi and Persianized Hindi (Urdu) had identical grammar, shared common words and roots, and employed different scripts. This common Hindi became the lingua franca of upper India after the eighteenth century. In the course of the nineteenth century, Hindi, written in the Devanagari script, developed a more standard style in competition with better-established languages like Urdu and growing languages like English. Hindi prose literature and novels in nineteenth century are partly responsible for the development of modern standard Hindi. ${ }^{33}$

Chatterji has identified five forms of Hindi or Hindustani. ${ }^{34}$ (1) The Urdu language, as spoken with a combination of Persian, Arabic, and Hindi words. It is written in Perso-Arabic, which is the Arabic script for the Persian language. Its vocabulary is highly Persianized and its literary use did not emerge before the end of the seventeenth century. In its highly Persianized form, High Urdu is a language of Muslim culture and poetry in India. (2) High Hindi or Devanagari Hindi, which has a grammar identical to Urdu but employs the Devanagari script. It uses many words from the regional Hindi (Prākrit) and dips deep into Sanskrit for words of higher culture. Perso-Arabic Urdu and Sanskritized Hindi share a common element or form; this common element is Kharī Bolì. 'Sanskritized Hindi' was not invented during the nineteenth-century. It can be traced not to debates on Hindi-Urdu or to the Hindi movement of the nineteenth and twentieth centuries but to the older 'literary tradition of Hindi.' A fifteenth-century poet in Gwalior may have been the first to incorporate Sanskritic themes (from the Mahabharat and the Ramayan) into Braj-bhāșā poetry. Awadhi in the Devanagari script and Sanskritic lexical style can be found in Sufi poems from the middle of the twelfth century. Sanskrit loan words appear in Hindi spoken around Delhi in the sixteenth century and seventeenth-century dictionaries of Hindustani vocabulary record Sanskritic loan words. ${ }^{35}$ It was a Brahman anthropologist who coined the term 'Sanskritization' to refer 
to the spread of Brahmans over India and the influence of their ideas and practices on the other groups of people they encountered on the subcontinent; for the most part, Sanskritization was a form of Hinduization, to the extent that Brahman communities tried to convert the people they encountered to Hinduism. ${ }^{36}$ (3) Hindustani, which is the name for the common Khaṛī Bolī that maintains in its vocabulary a balance between Perso-Arabic Urdu and Sanskritized Hindi. Chatterji has described it as "just Hindi not highly Sanskritised." It is the combination of and median between Urdu and High Hindi and as such was promoted strongly by the Indian National Congress as the only national language of post-independence India (more on this in later sections). (4) Then there is 'vernacular Hindustani,' a collective reference to regional dialects and forms of Hindi. These vernacular forms provided the grammar and vocabulary for Hindustani. As such, High Urdu and High Hindi can be considered refinements of vernacular Hindustani. (5) Finally, Bāzār Hindi or 'market Hindi' is a simplified form of types (1) and (2) and the language of the masses in India. It is the most used language in India and the language that is mentioned as the mother tongue by nearly 500 million speakers today. In this book, I use Hindi to mean High Hindi and quotidian, 'market' Hindi spoken with a preponderance of Sanskrit words, and written in the Devanagari script.

While the spoken history of modern Hindi can be traced to the New IndoAryan period, written forms of Hindi are more recent. Tiwari has argued that the use of Kharī Bolī for literary construction is not older than the seventeenth or eighteenth centuries. ${ }^{37}$ However, the use of a 'Nagari' or 'Devanagari' script dates from the seventh-eighth centuries. The meaning of 'nagari' remains unclear. However, since the script used to write Kharị Bolī was the script used to write Sanskrit, which is considered a heavenly language, ${ }^{38}$ the script came to be known as 'Devanagari.' 'Dev' means 'heavenly' or 'god' while 'nagari' means 'belonging to a city or town' or 'civil.' Devanagari, or literally 'divine city writing,' acquired its name from the belief that it probably originated in a city. ${ }^{39}$ By the eleventh century, the Devanagari script was fully developed and quite popular in middle and north India. Palm-leaf inscriptions in Devanagari from Gujarat, Rajasthan, and Maharashtra are available..$^{40}$ The Hindi script has developed differently from the Urdu script. These differences loom larger in formal and literary levels, where Hindi borrows its lexicon more from Sanskrit while Urdu borrows its lexicon more from Arabic and Persian. ${ }^{41}$

At least three applications of the term 'Hindi' are possible. 'Hindi' refers to a spoken language of recent provenance that in the modern era is distinguished from spoken Urdu. 'Standard Hindi' denotes a language written in the Devanagari script in a relatively standardized form. Its pronunciation and spoken forms are less standardized. Standard Hindi is in general use in most of central and north India. It gained currency in the period leading up to the 1860s as a "medium of education and instruction" and by the 1900s Hindi had become a "well established vehicle for journalism and 


\section{Politics of religion}

belles letters" in central and north India. ${ }^{42}$ Hindi is probably the third-most used language in the world. Due to its growing popularity in the Indian subcontinent and beyond, "Hindi in the Devanagari script" was recognized as an official language of India in 1947. Hindi's popularity must be understood in the context of the nineteenth-century movement to promote Hindi as the language of Hindus and Indians (more on this later). ${ }^{43}$ Hindi and Urdu were together for most of Hindi's history. Hindi's forerunner, Hindustani, was an amalgam of Hindu and Urdu, both languages spoken similarly but written with different scripts. ${ }^{44}$ Nationalism is partly responsible for their split. ${ }^{45}$ So is Indian politics. ${ }^{46}$

As a macroterm, 'Hindi' can also refer to an assembly of cognates. In this sense, Hindi is a collection of 49 cognates like Awadhī, Banjārī, Bhojpurī, Bundelī/Bundelkhandī, Chhattisgarhī, Haryānvīe, Kharī Bolī, Lodhī, Magadhī/Magahī, Mārwārī, Nāgpuriā, Pahārī, Rājasthān̄i, and Sargujiā. Historically, languages like Awadhī and Braj-bhāṣā should be correctly understood as cognates of Hindi. Stuart McGregor notes, "[i]t is historically and linguistically inappropriate to speak of early Braj-bhasha and Avadhi as dialects of Hindi, which they long preceded as literary languages." From the perspective of literary studies in the twenty-first century, however, they can be considered "as falling within a composite 'literary tradition of Hindi'." 47 The languages listed along with Hindi in India's census can be understood as part of the 'Hindi family.'

According to the 2001 census reports, 422 million Indians named Hindi as their mother tongue. Around 258 million Indians, or 25.09 percent of Indians named standard Hindi as their mother tongue. ${ }^{48}$ In this book, 'Hindi' always refers to modern, standard Hindi. ${ }^{49}$ Recently released data from India's decennial census of 2011 adds depth to our understanding of Hindi's position in India. In 2011, there were 528 million speakers of Hindi in India. ${ }^{50}$ Uttar Pradesh (U.P.) had the most Hindi speakers (188 million), followed by Bihar ( 81 million), Madhya Pradesh (64 million), and Rajasthan (61 million). ${ }^{51}$ The number of people who listed Hindi as their mother tongue has grown at a steady pace over the past 40 years, from 203 million in 1971 to 528 million in 2011. Decade over decade, Hindi users grew by 27 percent over 1971-1981, 28 percent over 1981-1991, 28 percent over 1991-2001, and 25 percent over 2001-2011. Hindi was not the fastest growing language during the last 40 years. That distinction belongs to Sanskrit, which grew by 176 percent over 1971-1981, a whopping 715 percent over 1981-1991, lost 72 percent users over 1991-2001, yet rebounded and gained 76 percent over 2001-2011! In real terms, however, the number of persons who listed Sanskrit as their mother tongue peaked at 49,736 in 1991 and stood at a meagre 24,821 in 2011 - well, meagre in Indian terms. ${ }^{52}$

Hindi is by far the largest language in India. Over the past 40 years, the strength of Hindi users as a proportion of the total population has steadily increased. In 1971, Hindi users accounted for 37 percent of the total 
population, 38 percent of the population in 1981, 39 percent in 1991, 41 percent in 2001, and 44 percent in $2011 . .^{53}$ Analysis of data on internet language trends adds further depth to our understanding of Hindi's reach in the modern world. According to a 2017 report by KPMG, the consulting firm, there are 521 million speakers of Hindi in India. Of them, 254 million are Indian language literates who use Hindi (over English) as their primary language to read, write, and converse. ${ }^{54}$ Hindi users will soon surpass English users in the digital age. Hindi Internet users are expected to surpass English Internet users by $2021 .^{55}$

Finally, 'Hindi' also marks a cultural state of affairs, referring to a geographic area - India's 'Hindi area,' so to speak - that is shaped by Hindi's history and its widespread use. While Hindi is used throughout India and around the world, the sources studied in this book are part and parcel of the life in India's Hindi area. ${ }^{56}$ The borders of Madhya Pradesh, Chhattisgarh, and Jharkhand constitute the southern and south-eastern boundaries of this area. The eastern border of Rajasthan and the northern border of Gujarat makes up its western limit. Bihar and Uttar Pradesh respectively mark the eastern and north-eastern limits of this Hindi area. Haryana, the Union Territory of Delhi, Himachal Pradesh, and Uttarakhand make up its northern limit. ${ }^{57}$ Users of modern standard Hindi in its spoken and written forms can certainly be found outside this territorial map and beyond India, but the 'Hindi area' denotes the limits of the linguistic geography of this book. A few more notes on the scope of this book are helpful at this point.

The book deals primarily with mainline Protestant materials in the Hindi area. The Hindi Christian sources I have studied are the handiwork of Anglican, Baptist, Congregationalist, Lutheran, and Methodist groups and institutions in the region. These materials are mostly from the Hindi Theological Literature Committee, Lucknow Publishing House, and the Indian Society for the Promotion of Christian Knowledge. Based, respectively, in Jabalpur (Madhya Pradesh), Lucknow (Uttar Pradesh), and Delhi, these publishers produce most of the Hindi-language Christian materials in the Hindi area. ${ }^{58}$ Among these publishers, the Hindi Theological Literature Committee deserves special mention. Founded in 1954, the Committee has been the most prominent producer and promoter of Christian works in Hindi. ${ }^{59}$ Publications by Roman Catholic institutions enrich the body of works published by mainline Protestant Christians in the Hindi area. The same can be said of the social footprint of Roman Catholic institutions in areas like health care, education, and charity. There is a rich history of Roman Catholic Hindi literature in the region. The Hindi area is home also to Syrian Catholic, St. Thomas, Orthodox, evangelical, and Pentecostal Christians. ${ }^{60}$ I pay limited attention to this diversity when examining Hindi Christian claims regarding the politics of language and religion in India. My sources are limited to mainline, Protestant Christian sources in Hindi.

In this book, I examine Hindi Christian works in independent India. The output of the Hindi Theological Literature Committee has been instrumental 


\section{Politics of religion}

to this study. Yet the Committee's work must be understood in the context of the much-longer history of Hindi Christian publications in India. An early example of Hindi Christian literature comes from 1877 in the form of a published account of a person's conversion. In pamphlet form, such accounts were quite in line with the type of publications popular at the time among missionaries who were trying to promote conversions. "Bhayaharn Dās," the convert, seems to have been illiterate. His conversion account is, as a result, written by one Rāmsimh, who attested to the account's veracity by "signing" the pamphlet. ${ }^{61}$ The slim pamphlet was titled Kaise Payya Muktidātā, arthāt Bhayaharnadās kā Itihās subtitled "How I Found the Saviour, or The Shepherd Convert of Monghyr" in English, and widely circulated. It was published by The Rev. Thomas Evans, a Baptist missionary at Monghyr (or Munger) on the banks of the Ganges river in Bihar, and printed at the Medical Hall Press in Benaras. The Welsh Baptists were also known for such publications as Ràm Parīkșa ("A Character Examination of Ram," in two editions), Shiv Parīkșa ("A Character Examination of Shiva," in two editions), and Sat Gurū kì Bulähat ("The Teacher's Call," in two editions). ${ }^{62}$

Many features of the pamphlet reflect strategic choices by its publisher. It was written in Kaithi, a popular local dialect of Hindi, for widespread appeal. The decision to use Kaithi over Hindustani suggests an interest in local and mass appeal rather than an appeal to the Hindu elite, the officers of the Raj, or an upper-caste audience. The account is polemic in nature and spends a considerable number of pages on the protagonist's first-person account of why he wanted to leave Hinduism, the religion of his birth. For Bhayaharn Dās, Hinduism was corrupt, dominated by greedy learned men who shamed people into guilt and therefore into supporting them, and was spreading its corruption from town to town. Dās does not dismiss Hinduism as polytheist or erroneous. Rather, the argument is aimed at the irreversible corruption of an admirable religion. The message to Hindus seems to be as follows: even if you think Hinduism is intrinsically acceptable, it is beyond redemption these days. This should motivate you to look elsewhere and you will see that Christianity provides a great alternative. It offers salvation and $m u k t i$ without ritualism and priests. The Protestant tinge of the argument is evident. So is the strategic nature of the choice of location where the pamphlet was published. Benaras is one of Hinduism's holiest sites, the city of Shiva and the Ganges, and as Diana Eck has described it, the city of all India, good life, and of death and liberation. ${ }^{63}$

Banaras remains a site of Hindu pride. ${ }^{64}$ The city has long been venerated as one of the seven cities of pilgrimage in Hinduism and is said to contain within itself all seven cities. The earliest Purānas (c. fourth-sixth cen. CE) speak of Siva's arrival in the city. The city's rulers promoted the Hindu tradition, supported schools of Sanskrit, and sponsored the education of Brahmans. Its rulers, merchants, Brahmans, and pilgrims jointly fostered the story of Kāśi (Banaras) as the sacred space with its divine links, ancient 
heritage, and power to heal and liberate. Colonial Christians reached Banaras at the tail end of the eighteenth century. Never more than a few hundred in number at a time, the Britishers regarded their time in Banaras as a "kind of moral exile" and Indians an "inferior race." ${ }^{65}$ Europeans lived on the outskirts of the city, following the colonial practice of segregation. They built a school and a Christian Missionary Society in Banaras. After the First War of Independence or Mutiny of 1857, the Raj emerged when the Government of India Act of 1858 transferred India's governance from the East India Company to the British Crown through the Secretary of State.

Indo-British relations in Banaras did not change under the Raj. Despite some debate, the link between missionaries and the government continued unabated. Pamphleteering was part of empire-endorsed Christian activity. ${ }^{66}$ In the nineteenth century, Banaras would become the site from which Hindi was promoted as the language of the Hindus - Sanskrit remained a language of the Brahmans. Given the place of Banaras in the Hindu imagination, the place of Sanskrit and schools of Hindu learning, and the Christo-colonial history in the city, the publication of the conversion account in Banaras in the local vernacular sought to achieve multiple aims through a single medium. It criticized Hinduism without denigrating the city, it took a swipe at holy and learned Hindus (Brahmans), it offered Christianity as a better religious alternative, and it spoke with the voice of an insider to a Hindu-heavy audience. The pamphlet's impact remains unknown. It was well-circulated but it did not lead to any mass conversions. Some may have converted after being influenced by this pamphlet or others of its ilk, but most probably the pamphlet suffered the same failure as the Christian enterprise in Banaras - which was largely unsuccessful when it came to conversions. ${ }^{67}$

Banaras was not the only site of Hindi Christian literary activity. Hindi translations of the gospels and Hindi Christian materials were a large part of the output of the Baptist missionaries in Serampore, with the first translation of Hindi gospels around 1818. An 1875 account of (Protestant) Christian vernacular publications mentions Benjamin Schultze's 1743 Summa Doctrinae Christianae as the "first Christian book printed in Hindustani." 68 The book was published by the Orphan House in Halle. By 1917, a comprehensive list of Christian literature prepared by the missionary council in central and north India catalogued 490 books in Hindi (this list is discussed later). For the purpose of this book, I commissioned an update of the 1917 list with materials published up till 2010. This updated 2010 catalogue of Hindi Christian works is the main source of published works for this book. The 1917 list is available online for public access. ${ }^{69}$ The 2010 catalogue is also available online for public access. ${ }^{70}$ The 1917 and 2010 catalogues of Hindi Christian works are discussed in chapter 2. The neglect of Hindi Christian works recurs in publications on Christianity in India. The India section of Asian Christian Theologies is a case in point.

Asian Christian Theologies, published in 2002, is an unparalleled collection of Christian sources in Asia. It catalogues works by 103 writers in 
17 languages: Bengali, Danish, English, French, German, Hindi, Kannada, Khasi, Malayalam, Marathi, Mizo, Naga, Oriya, Punjabi, Sanskrit, Tamil, and Telugu ${ }^{71}$ Despite its scope, it omits the vast majority of Hindi Christian authors and publications. Two Hindi Christian texts are cited among the nearly 1130 books in the India section of Asian Christian Theologies. James Massey's Masīhī Dalit: Ik Itihāsik Parīkshā ("Christian Dalits: A Historical Analysis"), published in 1993, ${ }^{72}$ and Vandana Mataji's 2-volume Śabd, Śaktī, Sangam ("Word, Power, Union"), published in 1995, make an appearance. ${ }^{73}$ The collection includes indirect references to other Hindi Christian works: Vandana Mataji, whose English-language works are referenced in Asian Christian Theologies, ${ }^{74}$ wrote hymns in Hindi; Viman Tilak's poetry crossed over Marathi and Hindi $;^{75}$ and James Massey does much work in Hindi. The absence of most works in Hindi can be partly explained by the book's focus on English-language sources. Asian Christian Theologies, the editors explain, offers "a survey of the writings in English." Yet the editors also tip their hand toward a broader goal when they write that they will survey English writings while "drawing on the writings in many languages of the region." 76 Given this appeal to other languages, the severe paucity of Hindi entries is conspicuous. The paucity is even more glaring in a multivolume compendium that makes the claim that "[e]xtensive research has been undertaken to ensure that a wide range of vernacular materials are included and outlined."77

\section{Language and religion}

In Constructing Indian Christianities, Bauman and Young raise an important question: Who is an Indian Christian? The query is complicated. What is the defining marker? Is it religion - Christianity? Is it a nation - India? Or, is it culture - a certain Indian-ness? Is it all these things, none of which can be packed into a neat definitional box? Is it none of them? They question whether a term like 'Indian Christian' "impose[s]" an "alien taxonomy on phenomena that in the final analysis remain fluid and stubbornly unreifiable." 78 Similar questions can be raised of a book that studies Hindi Christians. What is 'Hindi Christian'? What is a 'Hindi Christian' source or material or publication? Is it defined by its 'Hindi-ness'? Or, by its 'Christianness'? The danger of reification remains, but taxonomy is problematic, more so when it makes exclusive and permanent claims. The titular plural in Constructing Indian Christianities responds to the danger in naming through a counterclaim to conventional studies of Christianity in India. It hints at the state of permanent diversity that characterizes Christianity in India. Further, it claims that Christianity in India is a process, maybe not uniquely so but a process, nevertheless. Indian Christianities are always under construction.

'Hindi Christian' is a useful, if relatively unknown, descriptor. As a descriptive term, 'Hindi Christian' has a history. It has been in use at least since 1970 . The term appears in a preface by C. W. David to a popular 
book on Christian discipleship. David was the editor of the Hindi Theological Literature Committee at the time and was trying to use his influential perch to promote Hindi Christian works. He writes: "[i]t is the misfortune of Hindi Christian literature that it has very few readers. . . Hindi speakers are requested to awaken and, by reading good books, to remove their shame and be enlightened." ${ }^{79}$ David's appeal did not fall on deaf ears. By the middle part of the twentieth century, Hindi was a Christian language and had mass appeal through the many hymns and devotional songs (bhajan) in Hindi.

Congregations in central and northern India share Hindi. This shared heritage has fostered many of the Hindi Christian works still in widespread use. The movement in the twentieth century toward ecumenical relations catalyzed joint efforts among Hindi-using congregations and institutions. One such prominent collaboration is the production of Ârādhănā ke Gìt. It is the primary hymnbook of mainline Hindi-speaking churches in central India. The Madhya Pradesh Christian Council and the Methodist Church in India have been publishing Ārädhănā ke Gìt together for the last 45 years. Regular updates to Ārādhănā ke Gìt have kept the hymnbook up to date and have made it popular in Hindi-speaking congregations in Madhya Pradesh, Uttar Pradesh, and Bihar.

$\bar{A}$ rādhănā ke Gìt was commissioned by the Madhya Pradesh Christian Council as a revision of the Hindi hymnal, Masīhī Gìt Sangrah, in which "the paucity of contemporary Indian compositions, the dominance of difficult Western compositions, and the absence of easy, clear, and currently popular language was starting to be painfully felt." ${ }^{80}$ It was produced "so that one book might be printed which would be suitable for both Hindi and Urdu speaking areas in M.P., U.P. and Bihar." ${ }^{81}$ A Hymn Book Revision Committee began its work in the first week of March 1967 after conducting a survey of Hindi-speaking congregations to solicit views on which hymns and bhajans to include or exclude. The Methodist hymnbook was also undergoing a revision at the time, and in 1970, the Methodist Revision Committee joined the Christian Council's committee. Ārādhănā ke Gìt includes traditional and contemporary bhajans (devotionals). It includes well-known songs and anonymous compositions. Provenance, however, was not a major concern of the publishers. "We have made every effort," they explain, "to discover and acknowledge the authors and composers of the Indian songs and bhajans but still [we] are uncertain about many." 82 The main criteria for inclusions in the book has been a song's popularity. Most of the songs included in the book enjoy mass appeal and are in regular use. As such, the songs are recognizable and bridge the liturgies of congregations across a swath of India's Hindi area.

In addition to worship, theological education also unites Hindi-speaking congregations. Mainline denominations run joint seminaries dedicated to instruction in Hindi. Hindi, along with English, is the language of instruction in many seminaries in north India, some of which, like Leonard 
Theological College in Jabalpur, Madhya Pradesh, focus on preparing pastors and church leaders for Hindi-speaking congregations. Joint publication houses have also enriched shared theological education in Hindi. The Hindi Theological Literature Committee was set up as one such joint venture by a variety of denominations that use Hindi. The Committee has served as the primary patron of Hindi Christian publications in India. It distributes its output in India through a partnership with the Indian Society for Promoting Christian Knowledge. The Society has book shops across the country and promotes Hindi Christian literature beyond the Hindi area.

Hindi-speaking churches have established joint ventures in literature, liturgy, and theological education. Their use of Hindi has brought them together. This collective focus on Hindi has gained depth and patronage over the years. "The Principals of theological colleges, church bishops, pastors, publication houses, distributors of our books, boards, and missionary organizations from the Hindi regions are giving [us] their full support" to Hindi Christian ventures. ${ }^{83}$ This support represents a sea change in denominational attitudes toward Hindi Christian literature. Across a span of geographies, denominations, and contexts, Christians in India's Hindi-speaking region belie uniformity. Yet they have fostered ecumenical collaborations, common institutions of learning, standardized hymnbooks, common liturgies, and shared literature.

The intellectual history of religious studies in South Asia helps shed more light on the intelligibility, function, and usefulness of lingo-religious descriptors like 'Hindi Christian' in studying Christianity in India. Such descriptors allude to the role of language and religion in the formation of faith and identity. They point to a family of influences. The late Selva J. Raj wrote an ethnography of the ritual life of 'Santal Catholics' that shed light on the ways in which Santali tribal and Roman Catholic elements are combined in religious life. In its attention to the role of language, this book goes beyond Raj's work on Santal Catholics. The interface of multiple strands, Raj explains, enabled this community to "construct a distinct identity for itself that is authentically tribal, fully Indian, and genuinely Christian." ${ }^{4}$ Kerry P.C. San Chirico writes of the Khrist Bhaktas of the Hindi belt who worship Christ in personal and communal devotion, yet remain unbaptized and Hindu according to the religious taxonomy of the Constitution of India and its Census Bureau. They have adapted Catholic beliefs and Hindu temple practices to a bhakti mode of religious life..$^{85}$

Like Raj and San Chirico, Vasudha Narayanan draws attention to Hindus and Christians who are "multiritual" and "polytheological" in their religious expressions. Practices based on the view that religious lines are blurry permeate the religious landscape of India. As an instance, khrist bhaktas are part of the north Indian religious landscape. Rajasthan has pilgrimage sites shared by Muslims and Hindus. Hindus and Christians worship at The Church of the Infant Jesus in Bangalore. ${ }^{86}$ Hindu, Muslim, and Christian venerate Sister Alphonsa in Kottayam as a healer. ${ }^{87}$ Satya Sai Baba claims 
that he does not speak for any sect or doctrine but preaches respect, unity, and the glory of God. In similar vein, Hindus argue that that multiple paths lead to God. ${ }^{88}$ Forms of God are prolific, and gods can exist as partial and particular manifestation of the 'one' God. ${ }^{89}$ Angelika Malinar argues that the theology of the Bhagavad Gita, one of Hinduism's most sacred and influential scripture, can be called 'cosmological monotheism' because the Gita presents Krishna as the "highest and only god of liberation and creation" while acknowledging other gods as "partial manifestations" of Krishna. ${ }^{90}$

Similarly, Islam teaches that God sends different prophets to different peoples. Chapter 16, verse 36 of the Koran is an ideal example of this sentiment: "We indeed sent a messenger unto every community, 'Worship God, and shun false deities!' Then among them were those whom God guided; and among them were those who were deserving of error." Other verses affirm the idea that every community has its own messenger (10:47), its own book (45:28), and is called to worship God (21:25). ${ }^{91}$ God has revealed many ways and many religions and many creeds and many rites and many legal codes. ${ }^{92}$ As such, "variegated religious forms do not contravene the validity and efficacy of one another" but are part of the repeated calling back of humans to God..$^{93}$ Raj and Dempsey say of Christianity in India that it is "neither homogenous nor uniform but essentially plural and diverse." 94 "Christianity" in India is a congeries of beliefs and practices inspired by faith traditions and social histories whose constituents are never too far from change..$^{95}$

David Mosse has critiqued "short-time-frame ethnographies" that unearth cultural adaptations with a bias toward disjunctions between culture and Christianity and that pay inadequate attention to the stability in beliefs and practices embedded in centuries-long traditions like Orthodox and Catholic Christianity in India. As a "source of distinctive forms of thought, action, and modes of signification" he writes, studies of "profoundly localized" Christianity that eschew presenting the relation between "culture" and "Christianity" as continuity or rupture offer a necessary corrective to studies of Indian Christianity. The Tamil Catholicism of the pseudonymous Alapuram in his work charts a rich terrain with features that have gradually emerged from the "complex intercultural space" between Catholicism and Tamil cultural forms. ${ }^{96}$

Drawing on Mosse's corrective in The Saint in the Banyan Tree, I explore the space created by Hindi Christian materials between Hindi "culture," Hindu-Christian relations, and the politicization of language and religion in India. I interrogate the many ways in which Hindi Christians have created credible and recognizable linguistic features that seek to function in a religious milieu that is affected by Hindu practices and Hindi cultural forms. I study the particular ways in which Hindi and Christianity continue to function in India. This is partly in response to Mosse's critique that most scholarship on Indian Christianity has sought to either find a gap between 'local' culture and Christian claims or to suggest they are undistinguishable. 
Mosse's research on Tamil Catholics did not support this division; and, he therefore invites scholars of Indian Christianity to take a deeper look at these relations. This book accepts Mosse's invitation. It looks at the relation between a language and certain religious ideas. In line with Mosse's findings, Hindi Christian materials reveal neither a continuity with existing claims nor a complete rejection of available resources. Rather, a middle ground emerges that is clearly marked to insist Christianity is culturally Indian, idiomatically Hindi, and home grown.

\section{The milieu}

In Religions in Practice, John R. Bowen describes a private $p \bar{u} j \bar{a}$ (worship) in a village in Madhya Pradesh. A father gathers his family, lights a cow-dung cake, sprinkles water around the fire, and offers portions of prepared food to the fire. The fire purifies the food. The food is now blessed. Portions of food are offered because purified parts can cleanse the whole. Blessing all the food by sacrificing parts of it also allows the blessed food to be shared. The remaining food - now blessed food (pras $\bar{a} d)$ - is then shared in a family meal..$^{97}$ Family rites and public festivals permeate the religious landscape of India. Accompanied by chants and prayers, bhajans and pujā resound through the many villages, towns, and cities in the region. Growing up in a small town in Madhya Pradesh, I woke up most days to sound of templebells and bhajans coming from the Hindu temple down the road. Once in a while an $a z \bar{a} n$ would break through from the mosque across town. Festival plays, street theaters, religious holidays color the landscape with a religious hue. Bhakti shapes north India. Hawley's observation 30 years ago is apt even today: "north India [is] a place where bhakti is spoken." ${ }^{98}$ Ganesh, Hanuman, Krishna, Lakshman, Lakshmi, Ram, Saraswati, and Sita adorn temples, books, factory floors, shops, schools, hospitals, government offices, calendars, posters, clothes, and bodies. The image of God, in Diana Eck's apt phrase, is "visible everywhere in India." ${ }^{99}$ Bhakti (devotion), śraddha (veneration), and $p \bar{u} j \bar{a}$ are the means of reaching out to God.

Bhakti is a religious language and a way of being. One is a devotee of, and in relationship with, God. These relations are complementary, and in most cases reciprocal. Devotees worship, bring gifts, and go on pilgrimages. The deities protect, grant wishes, and help manage the ups and downs of life. I use bhakti in this broader sense to refer to the general relationship formed between a devotee and the divine. The relationship between a bhakt and her $\operatorname{god}(\mathrm{s})$ is personal, reciprocal, continual, and special. A devotee may have a special relationship with one main god while engaging other minor gods as needed. Hindu devotees shift among different main gods at different occasions or elevate more than one god above other gods or may assign different religious meaning to one god elevated above others. Within bhakti traditions, however, the tendency is to elevate one god above others and to foster life-long loyalty to one god over other gods. 
The word 'bhakti' emerged around 2500 years ago. It appears in the Svetasvatara Upanishad and the Bhagavad Gītā, by far the most influential Hindu scripture on bhakti. Bhakti denotes love or devotion directed to a deity or God. ${ }^{100}$ At the root of the word 'bhakti' is the Sanskrit verb bhaj. In the Rig Veda (c. 1700-1500 вСE), bhaj meant to divide, distribute, allot, or apportion. The verb later developed to mean to obtain as one's share, to partake, to receive, or to enjoy. It has a noun form, bhakta, which denotes a worshipper or votary. By the time the Mahabharata was composed during 300 вСЕ to $300 \mathrm{CE}$, bhaj acquired a vassalic form; it meant to declare for, prefer, choose (e.g., as a servant) or to serve, honor, revere, love, or adore. Bhakta acquired commensurate connotations in the Mahabharat, where it meant to be engaged in, occupied with, attached to or devoted to, loyal, faithful, honoring, worshipping, and serving. ${ }^{101}$

Since its origin, bhakti has existed as one path to liberation among other paths - like those of juñana (knowledge), karma (action), and other types of disciplines. In the Bhagavad Gitan, as an instance, the bhakti path to liberation is mentioned in conjunction with the path of knowledge and that of proper action. Around 1200 year ago in Tamil Nadu, however, a new form of bhakti emerged that understood loving devotion to God as the only path to liberation. The great eleventh-century teacher, Rāmānuja, exemplified one interpretation of this type of devotion-based liberation. Rāmānuja draws a distinction between two types of bhakti, a lower bhakti and a higher bhakti. ${ }^{102}$ Lower bhakti is a discipline of knowledge in which a devotee seeks a better understanding of Brahman (God). This discipline of knowledge is a form of indirect knowledge of God and is based on the scriptures. Through junana-yoga, which is the systematic exploration of scripture under the guidance of a teacher, a devotee comes to know God. The discipline of knowledge complements a discipline or proper actions (karma-yoga), which consists of doing what is obligatory and permissible without attachment to the fruits of those actions. The discipline of indirect knowledge is then a discipline of knowledge-and-work. When done with the intention of the love of God, this combination discipline constitutes a discipline of devotion (bhakti-yoga). Rāmānuja suggests that too much of one's ego still survives in love for God. Hence, this form of bhakti constitutes a lower form of bhakti. While lower, this type of discipline helps a devotee walk on the path toward the higher form of bhakti.

Higher bhakti is a form of direct knowledge of God. It occurs in the form of an epiphany of the divine, an "ever-deepening relationship of intimacy," with the divine. It is still cognitive in nature and a form of knowledge, even if an ineffable intimate knowledge of God. Even as Rāmānuja locates knowledge of God in devotion of God, bhakti for him is still grounded in "the context of necessary social and religious obligations." 103 Bhakti did not remain in Tamil Nadu but spread outward, reaching the west, then the north and eventually reaching the eastern parts of India. As the personaldevotional form of bhakti spread from southern India, many of the main 


\section{Politics of religion}

features set during its time in Tamil Nadu spread with it. As bhakti spread throughout India, it acquired certain features. Some features separated it from the 'intellectual' bhakti of Rāmānuja. Yet, as Schelling notes, many of its main features were set in its Tamil Nadu days. These features include a devotion that is substantially personal, expressively emotional, scornful of doctrines, suspicious of religious authorities, defiant of orthodoxy, physically immersive, intentionally disruptive, grounded in communities, egalitarian in outlook and distinctively open in its symbols and songs. Further, bhakti is mostly in the form of oral poetry and songs and not in the form of literature. ${ }^{104}$

Bhakti in north India is characterized by a few features. It constitutes a deep and personal relationship between a devotee and her God. Further, it is reciprocal: the devotee offers praise, worship, and gifts and receives blessings. It is also continual: a devotee may not visit a temple or pray ritually every day, but the relationship is a constant presence in the thoughts and acts of the devotee. She expects that the divine sees the devotee whenever the divine is called upon. Finally, bhakti tends to be broadly exclusive. A devotee may pray to different saints or holy people at different times, but bhakti is usually layered, with one supreme deity the focus of devotion and a range of secondary 'saints' available as needed. While a bhakt can be in relationship with multiple divinities for particular purposes - as an instance, Sister Alphonsa for health, Ganesh for good luck, Lakshmi for wealth, Saraswati for wisdom, and Hanuman for protection - a specific divinity primarily occupies the devotee's devotion. It is in the context of this larger, four-fold sense that Hindi Christian sources express bhakti. Bhakti as found in Hindi Christian sources reflects a combination of 'southern' bhakti - with its fusion of personal devotion and proper actions - and pan-Indian bhakti, with its passionate, unorthodox, egalitarian form. Hindi Christian notions of devotion and love of God do not scoff at rituals or doctrines. Yet at their core lies a commitment to the liberation of the body and soul in this world and the world to come.

Bhakti and Christianity share motifs and vocabulary in India. A comparison by Sabapathy Kulandran in 1957 listed the following shared features. ${ }^{105}$ In their essence, both modes of religious expressions describe the human response to the divine. Both religious traditions embody a whole-hearted trust and commitment to another. They characterize God as the 'other' in whom one places complete trust. The power of trust can be found in the love poems of Mirabai, the seventeenth-century bhakti saint. Mirabai sings:

He's bound my heart with the powers he owns, Mother He with the lotus eyes.

Arrows like spears: this body is pierced,

And Mother, he's gone away.

When did it happen, Mother? I don't know 
But now it's too much to bear.

Talismans, spells, medicines -

I've tried, but the pain won't go.

Is there someone who can bring relief?

Mother, the hurt is cruel.

Here I am, near, and you're not far:

Hurry to me, to meet.

Mira's Mountain-Lifter Lord, have mercy,

Cool this body's fire!

Lotus-Eyes, with the powers you own, Mother,

With those powers you've bound. ${ }^{106}$

One moment Krishna is far. The other moment he is near and ready to meet. God may be the 'other' to whom a bhakt relates, but God/Krishna is not completely removed from the devotee. Bhakti, Kulandran continues, rises above legalism and ritualism. As such, bhakti traditions undermine caste claims and caste-based distinctions. Important differences remain. The most important difference, Kulandran argues, concerns the nature of God and the sources of salvation. Unlike Christianity, which posits a God distinct from creation and Jesus Christ as the only source of salvation, bhakti tends toward monism and offers itself to Hindus as one among many paths to liberation.

David Scott has also characterized Christianity and bhakti as responses to the sacred. He goes as far as to conflate the two phenomenon and jointly call it "Hindu and Christian Bhakti." In Scott's construction, Christianity and Hindu have a "common" human response to the divine in the "personalist tradition of religious devotion of bhakti" that both Christianity and Hinduism share. ${ }^{107}$ Given the overlaps between Christianity and Hinduism, Scott proposes that bhakti can be used as the gateway to a fuller Indian understanding of Christianity. Bhakti is the bridge that links the Christian faith to the Hindu faith. Hindu and Christian bhakti, Scott explains, is characterized by love of God, personal devotion to God, the experience of grace, utter self-surrender to God, and the power of God's love. In Scott's construction of religion, bhakti provides the proper orientation for "outward" religious acts like worship and devotion and "inward" religious acts like faith and love. ${ }^{108}$

Bhakti and Christianity further share a concern for social relations. Poems of the bhakti tradition, Schelling writes, started to take shape during the eighth and ninth centuries, drew inspiration from excluded sections of society, challenged social hierarchies, and spread revolutions across kingdoms. Bhakti has led to uncontainable movements for spiritual freedom and fostered persistent demands for social and economic equality. It has nurtured the human yearning to connect with something greater and served as a way to experience the transcendent. "At the root of bhakti," Schelling observes, "coils the formidable old hunger for human freedom, a sense of 


\section{Politics of religion}

the world's inexplicable mystery, and the conviction that each of us forms some personal relationship to that mystery." 109

Not all comparisons between Christian devotion and bhakti were appreciative or positive. Some comparisons sought to present bhakti as the antidote to Christian colonialism in India. As Dipesh Chakrabarty and Tapan Raychauduri have noted, bhakti as loving devotion became a source of political unity among nationalist authors in the nineteenth and early twentieth centuries. ${ }^{110}$ Comparativist scholars during the British Raj were wary of certain forms of bhakti. George Abraham Grierson (1851-1941), the leading ethno-linguist, found much to admire about the bhakti-focused writings of Indian religious leaders like Sitaramsharan Bhagvan Prasad (1840-1932). Grierson would go so far as to trace the origin of Hindu bhakti to early Nestorian Christianity via the theology of the great eleventh-century Hindu theologian, Rāmānuja. He retreated from that claim later. ${ }^{111}$ Despite his retreat, Grierson found many parallels with Christian motifs in Hindu bhakti: God's unwavering love for humanity, God's grace, self-surrender, abandoning the world for God, cleaving away from sin, being 'reborn' as a bhakta. Yet not every form of bhakti earned a positive review. Grierson was critical of Krishna-bhakti, which he considered was based on the love of a man for a woman and corrupted by an extreme form of bhakti veering on the edge of lust. Contrary to Krishna-bhakti was Ram-bhakti, which was based on the love between a father and a son, lacked any hint of sensual licentiousness, and was a good approximation of the Christian motif of God's love for humans. ${ }^{112}$

Arun Jones draws a distinction between certain versions of Christianity and bhakti traditions, which he designates 'local religion.' He argues that nineteenth-century evangelical Christianity found its place in the religious milieu shaped and nourished by bhakti. ${ }^{13}$ In the motifs and practices of bhakti groups, evangelical Christianity unwittingly found substantial echoes. Jones identifies five areas of resemblance. ${ }^{114}$ In theology, both religious groups looked to a divine savior for liberation. Devotees sought a personal, intimate relationship with their savior. Both groups further shared a form of religious expression that emphasized personal experience of the divine rather than rituals and doctrines. This form of religious expression fostered vernacular expressions. In terms of social outlook, bhakti and evangelical Christianity shared a reformist impulse that provided counterpoints to formal religion, orthodoxies, and religious hierarchies. Both religious traditions further stressed on communal formation as the main means to religious devotion. Worshipping communities were the primary locus of bhaktas and evangelical Christians in North India. (Jones writes of evangelical Christians in Hindi North India but has very little to say about the Hindi-ness of Christianity in North India.) Finally, both groups shared a demography, drawing members primarily from groups on the periphery of society.

Despite the sharing of motifs and practices, Jones notes, bhakti and Christianity could not be (con)fused in nineteenth-century north India. 
Important differences remained. As an instance, where bhakti was henotheistic in outlook, evangelical Christianity had a different sense of divine selfexpression. Similarly, where bhakti groups challenged social hierarchies in their motifs and form of organization, evangelical Christianity emphasized the development of personal holiness, though Jones seems to suggest that evangelical Christianity had high(er) degree of social activism than bhakti traditions in North India. Jones's general thesis is on point: nineteenthcentury evangelical Christianity in India found hospitable spaces in the religious milieu shaped by north Indian bhakti traditions. His observation that this hospitality was "coincidental" and "unwitting," however, needs to be qualified. ${ }^{115}$ On the matter of the relationship between motifs in bhakti traditions and motifs in the evangelical Christianity of Hindi north India in the nineteenth-century, Jones may be right. But as I discuss in following sections, the devotional hymns of mainline, Protestant Hindi Christians in the twentieth-century show an affinity with and explicit adoption of the motifs and language of bhakti. In the Hindi area, connections between Hindi Christianity and bhakti appear weak at first glance. While the practice of bhakti populates the Hindi area, I have not found direct references in Hindi Christian sources to the works of the bhakti saints like Ravidas, Kabir, Nanak, Surdas, Mirabai, and Tulsidas. Yet Hindi Christian books and hymns demonstrate a robust affinity to the ideas and terms of bhakti. While a Hindi Christian may not describe Christianity as a bhakti religion, thematic analogies between the world of bhakti and Hindi Christian expressions are evident. Hindi Christian devotionals provide the most fertile ground to examine this evidence. ${ }^{116}$

Hindi Christian hymns include direct references to bhakti and bhakts. Noticeably, 'official' collections of Hindi Christian hymns present Christian $\bar{a} r \bar{a} d h a ̆ n \bar{a}$ as bhakti. Ārādhănā ke Gìt has a special place in Hindi Christian liturgy given its role as a primary source of devotional songs and other bhajans. It has also led to standardization of Hindi Christian devotionals. $\bar{A} r a \overline{d h} a ̆ n \bar{a}$ ke Gìt has wide acceptance among mainline Protestant Christian congregations that use Hindi. The hymnbook is also noteworthy for its reliance on the motifs and vocabulary of bhakti. The topical index of $\bar{A} r \bar{a} d h a ̆ n \bar{a}$ ke Gìt lists songs for 'Worship and Adoration' under the category 'Ārāadhănā.' In this popular hymnbook, ārādhănā is synonymous with bhakti. The publishers of the hymnbook categorize all songs related to the adoration and worship of God as "Ārādhănā (Bhakti)." ${ }^{117}$ In their construction, Christian worship is bhakti. A few examples follow (emphases mine). The first hymn in the hymnbook describes Christian devotion as bhakti. In a Hindi rendering of 'How Great Thou Art,' its fourth verse reads:

$\bar{A} e g \bar{a}$ khrist sāth baḍ̄ mahimā ke, Sāth usăke hogā ek ānand mahān, Tab bhakti-bhāv aur dinătā se mairim jhukkar,
Christ will come in great glory, With him shall be great joy, Then bowing with humble devotion, 
Gāumgā yah, "prabhu, kaisā mahān.” I shall sing, "Lord, How Great Thou Art."

(Number 1; translated by R. M. Clark)

The third hymn uses bhakti for devotion:

Ab àe tere $p \bar{a} s$

Ārādhănā karne ko,

Praśamsā bhakti se karem, Aur prārthănā saccī ho.
Now we come close to you, So that we may worship you, May our praise be devoted to you, And our prayers be true.

(Number 3; anonymous composer)

So does Hymn 29:

Duniyāim kā racne vālā vahī, Bhaktom ke dil kà ujālā vahì, Pāpin kāran janmā vahī, Sülì par caṛne vālà vahì.
$\mathrm{He}$ is the one who creates the world, He enlightens the heart of devotees, $\mathrm{He}$ is the one born to fix sin, $\mathrm{He}$ is the one to climb the cross. (Number 29; composed by Ahsan)

And Hymn 403:

Bhakti se, stuti se, Is din ko pavitr mānem. Khrist y'̄śs ke dvārā mere, Pāpoin ko kṣamā kar tu de,

Bhakti se, stuti se, Is din ko pavitr mānem. $\bar{A}$ nand se āem tere ghar, $\bar{A}$ rādhănā ho saccāì se; Hamārī bhakti aesī ho Ki bhāe vah svarg mein tujhe.
With devotion, with praise, Consider this day holy. Through Christ Jesus, You forgive my sins.

With devotion, with praise, Consider this day holy.

May we enter your house with joy,

May our worship be true;

May our devotion be such

(Number 403; “O Happy Day,” translated by Phillip Doddridge)

Evangelical Christians in north India in the twentieth century have also described their devotion as bhakti. Jivan Sangit ("Life Music") was published in 1994 and is a popular publication among evangelical Christians in Madhya Pradesh. It is the primary hymnbook of churches affiliated with Mid-India Christian Services, a well-established evangelical Christian organization based in Damoh, Madhya Pradesh. Hymn 2 of Jivvan Sangit is the popular Hindi Christian hymn "Terī Ārādhănā Karūim." Its second verse reads:

Srștīi ke har ek kan kan mein Chāyā hai terī hì mahimā kā rāj Pakṣì bhī karte haim terī praśamsāa
In every kernel of the universe Your glory reigns

Even the birds sing your praise 
Har pal sunāte haim ānand kā rāg

Merì bhi bhakti tujhe grahan ho

Hṛday se prārthănā karūim.
Sounding your joy always

May my worship be acceptable to you

This is my heartfelt prayer.

(Number 2; anonymous composer)

Then there is "Śaran meì äe haim hum," Hymn 329 in Jivvan Saingit, which has a counterpart in a Hindu devotional song of the same name. Between the two songs, only some words are different. Among these slight changes, $y \overline{i s} u$ (Jesus) in the Christian version is bhagvan (Lord) in the Hindu version. The third and fifth verses of the hymn respectively read:

Na hum mein bal hai

$\mathrm{Na}$ bum mein shakti,

$\mathrm{Na}$ bum meri sādhan

$\mathrm{Na}$ hum meri bhakti.

Tumbāre dar ke hum haim bhikāri, Dayā karo he dayālu yīśu.

Pradhān kar do mahān bhakti, Bharo hamāre meì jũān shakti.

Narak nāśak ho krūs dhārī,

Dayā karo he dayālu yīśu.
We lack strength, We lack power, We lack the means We lack devotion.

We are beggars at your doorstep, Show us mercy, merciful Jesus.

Grant us great devotion, Fill us with powerful wisdom. You are the hell-destroyer, the cross-bearer Show us mercy, merciful Jesus. (Number 329; anonymous composer)

Hindi Christian bhajans, like their bhakti counterparts, use vernaculars and mix and match terms from a variety of linguistic contexts. Consider Hymn 511 in Ārādhănā ke Gìt:

Terī nazar ke pyāse haim hum, We thirst for your gaze, Tujbse dua yah karte haim bum. That you look upon us, we beseech you.

Tū hai hāmī, tū hai svāmì, You are our advocate, you are our master,

Tü hai prem apār.

You are love unbound.

Tū bì dān, tū hì mān, Tū hai jag kà ādhār.

You are the gift, you are the honor, You are the foundation of the world.

Tū hai śakti, tū hai bhakti, Tū hai tāranăhār.

You are power, you are devotion, You are savior.

(Number 511; lyrics and tune by D. M. Daniel)

The song is listed as hymn of $\bar{a} r \bar{a} d h a ̆ n \bar{a}$ (bhakti) and exemplifies the linguistic mixing of languages and concepts that occurs when bhakti traditions and 


\section{Politics of religion}

Christian worship come together. Nazar is an Urdu word via Arabic. Hāmi is Arabic in origin and Svāme and Apār are Sanskritic in origin. Hām is an Arabic loan-word that means 'supporter' or 'advocate.' It is sometimes also conflated with the Arabic $b \bar{a} m \bar{\imath}$, which means 'to confirm' something, as in hâmī bharănā (to agree with, to assent to). ${ }^{118}$ In the next verse, mān and $\bar{a} d h \bar{a} r$ are borrowed from Sanskrit. Finally, Sanskrit provides śakti, bhakti, and täranăhār, which respectively mean power, devotion, and one who enables a crossing over. The combination of nazar, hāmin, svāmì, bhakti, and tāranăhār in the Hindi hymnal asks a singer of the hymn to perform a type of multilingualism where understanding the full meaning of the hymn depends on facility with a range of linguistic terms in Urdu, Hindi, Arabic, and Sanskrit. Hindi Christian hymns share other ideas with bhakti traditions. ${ }^{119}$ A recurring theme in popular Hindi Christian hymns, for instance, recalls sacrifice and surrender. A devotee brings herself to Christ, surrenders, seeks, shelter, and receives freedom or mukti from time and death. Consider these examples:

\section{$I$.}

Dil merā le le, pyāre yīsu, tūne ise banāyā hai, ismeì tu apnā ghar banā le, jiske liye hì yah banāyā hai.

Pavitr àtmā kā yeh ho bhavan, agni ke baptismā se, har jagah, har samay dīin gavāhì, jaisā yeh usne sikhāyā hai.
Take my heart, $\mathrm{O}$ dear Jesus, You are the one who has made it, Make in it [now] your own house, For this only it was made.

May the Holy Spirit ${ }^{120}$ live here, By the baptism of fire,

Everywhere, always, may I witness, Just as He has taught this. (Number 311; anonymous composer)

II.

Yiśs tu ne kiyā nihāl, jab maìi śaran meri terī àyā.

Jesus, you freed me, when I came under your refuge.

Yīśu ākar tere dwār, barkat pāì beśumār, kripā terī hū apār, mere dil kā mail mițāyā.

Jesus, having reached your door, countless blessings I received, Your mercy was unbound, as it cleaned my dirty heart.

Jo terī śaran memi āe, vah pāpoì se bac jāye, man meì pāvan àtmā àe, isko maimne hai àjmāyāa. 
He who comes to your refuge, from his sins he is saved,

He receives the Holy Spirit, in this witness I have shared.

Hai dās terā viśvāsì, kāṭ̂̀ tūne kāl kì phāinsì, dhan-dhan amar lok ke vāsì, darśan maimne terā pāyā.

Your believer is a servant, you have cut the noose of time, Blessed-blessed those in heaven, your vision I have received.

(Number 282; lyrics and tune by Premdas)

In the context of bhakti and of Hindu religious vocabulary, $p \bar{a} p$ refers to sin, evil, wickedness, or a wrong. ${ }^{121}$ In bhakti, one turns to God to seek liberation from the effects of sin, which are generally understood as forms of self-attachment, mistaken desires, or evil acts. The effects of such evil and sin can keep one bound to life and the cycle of rebirths. As a describer of sin and evil, the word pāp - along with its antonym puny (meritorious, auspicious) - functions in both Christian and Hindu circles. It is common in Hindi hymns to beseech Christ for safety and a personal relationship:

\author{
Bolo jay milkar jay \\ bolo jay yīśu kī jay. \\ Bolo jay, jay, jay. \\ Prem tere kī yahī rìt: \\ Man meì bhar de terī prìt, \\ tere prem ke gāyeim gìt. \\ Khidmat apnī le mujh se, \\ is mandir mein tū hì base, \\ jag me terā nàm phaile.
}

Sing his praise, join his praise Sing his praise Jesus' praise. Sing his praise, praise, praise.

Tis' the nature of your love: Fills one's heart with your love, We sing songs of your love.

Take from me your service [Lord] In this temple may you stay, May the world hear your name.

(Number 47; anonymous composer)

With bhakti literature, Christian hymns further share an erotic terminology. Mirabai is well-known for her love-filled songs directed at Krishna, her playmate and lover. ${ }^{122}$ Christian hymns recall the lover's relationship that exists between Christ and his bhakt in comparable terms and suggest a two-way relationship in which a devotee surrenders to Christ and is at the receiving end of Christ's love. Consider this Hindi translation of a German Lutheran hymn:

Maim prem apār ko nit sarāhtā jo yiśu tujh se prakat hai, aur apne ko samarpit kartā tujh ko jo merā premī hai.
I always praise the love unbound That appears from you, O Lord, And I surrender myself To you who's my lover [Lord]. 
Tū mujhse kaisī prìtī rakbtā! Man terā mujhko cāhtā hai. Is prem se sab prabhāvit hotā vah jo kuch mere bhitar hai.

He prem asēm jo swarg se $\bar{a} y \bar{a}$
How it is that you love me! You are in love with me. This love changes everything That which is inside of me.

O love unbound who came from heaven

maim terā hūim, tū mujh ko bhāyā. I am yours and in love with you.

(Number 7; original German, lyrics by Gerhard Tersteegen, tune by Dimitri Bortniansky, Hindi translator unknown)

The lovers' relationship described in Hymn 7 does not exist in a vacuum. It complements communal forms of worship. The relationship of bhakt communities to the singer saints of India is complicated. Nirguna bhakti, Hawley and Juergensmeyer note, is not readily hospitable to institutions, temples, priests, and structures. The resistance of nirguna poets to organized religion typified in the poetry of Kabir was particularly attractive to those seeking to escape structures of caste and creed. ${ }^{123}$ Kabir's critique of Hinduism and Islam on one hand and his relationship with a community of listeners and yogis who rejected Hindu hierarchies on the other, however, reflects the very concrete ways in which society and politics impact religious practices.

Christian devotion is imprinted with the Christological core embedded in Hindi hymns. As one consequence of this imprint, Christian Hindi hymns are clearly not devotionally 'layered' with primary and secondary deities as can be found in bhakti bhajans. While local healers and saints do figure in devotional schemes, Hindi Christian sources are distinct from bhakti devotionals in their exclusive devotion to Jesus. The Christological core has also led to the dominance of saguna forms of devotion rather than nirguna forms of devotion in the body of Hindi devotionals. ${ }^{124}$ Key features of nirguna and saguna devotions like longing, community, refuge, love, and surrender are nevertheless part of some of the most well-known Hindi Christian hymns.

Bhakti traditions pay attention to the relationship between teacher and disciples. In concrete terms, the values and practices of a worshipping community are passed down from teacher to teacher. Such teachers depend on their community of disciples to manifest the teachings and devotion to God. The worshipping community is the site of religious expressions, growth, and transmission. The Kabir panth has valued the transmission of faith and worship from gurus to disciples. ${ }^{125}$ Mira's songs are best experienced in "the company of other worshippers." ${ }^{126} \mathrm{Or}$, in the words of a famous Hindi Christian hymn:

Dhanyavād sadā prabhu khrist tujhe

tere sanmukh śiśs navāte haim, hum terī Ārādhănā karne ko mandir mein tere àte haim.
We give thanks to you always Jesus Christ,

We bow our heads before you, To worship you [and sing your praise] We gather in your temple. 
Dhany vìrom kā is mandli ke, Give thanks for the brave ones of this church

tere nām par jo balīdān hue, hum unke sāhas tyāg ko le nity àge barhte jāte haim.

Those who martyred in your name, Taking on their valor and sacrifice We keep on moving [boldly] ahead.

(Number 22; original Hindi, lyrics by M. R. Utarid, tune by Goodwin R, Utarid)

Hindi Christian hymns and bhakti devotionals echo a variety of themes. These themes include a strong personal bond between God and devotee, a two-way relationship with mutual obligations, personal devotion in the context of and as part of larger communities of worship, and a certain exclusivity in a devotee's focus on a supreme deity who meets her need for love and salvation. The cultural milieu of Hindi Christian works has been shaped by ideas other than the motifs found in bhakti traditions.

The Indian subcontinent has a long history of Christian scholarship and this history can be traced to India's earliest Christian communities in the first century CE. Early trade routes and later colonial expansions brought converts in contact with Christian communities outside the subcontinent. Hindi Christian literature exists as part of this Christian milieu in the subcontinent. However, it seems that Indian Christian scholarship has minimally interacted with Hindi Christian materials. While the influence of Western authors on Hindi Christian writers is evident, Hindi Christian writers have for the most part ignored Indian Christian scholarship in other languages. Hindi Christian writers may have engaged their Western predecessors but a study of Hindi Christian materials reveals that Indian Christian scholarship in other languages has not been an influential partner of Hindi Christian writing in the way Western scholarship has. Let us look at two examples.

The bibliography of Dayal's popular Hindi-language textbook on Christianity (published in 2005) presents a list of 74 books. Eleven of the 74 are by Indian authors. Western sources dominate the list, led by the works of D. M. Baillie, Karl Barth, Emil Brunner, Mircea Eliade, David Ford, John Hick, John McQuarrie, Reinhold Niebuhr, Karl Rahner, and Paul Tillich. Only five of the 11 Indian-authored books are in Hindi. In a widely-used Hindi-language textbook, then, only 6.7 percent sources are in Hindi. Other Hindi-language textbooks do not fare any better. The 23-book bibliography of Masih and Peter's Prabhu Yeśu kì Jìvanī aur Sevākāry (2007) lists only one Indian author - the rest are from the West. All its sources are in English. The 30-book bibliography of Khan's Christian ethics, Khristīy Nìtiśāstr (2009), lists only two books by Indian authors (one by H.H. Titus, another by Joseph Vadakumcherry). Again, all its sources are also in English. What explains this state of affairs? Are Hindi Christian writers generally unaware of Indian Christian sources in English or other languages? Do Hindi Christian authors have limited access to translated editions of non-Hindi sources 


\section{Politics of religion}

(assuming they are restricted to the use of Hindi)? Are non-Hindi sources from India unhelpful and hence underutilized on purpose?

An analysis of the interactions between Indian Christian theology and Hindi Christian scholarship sheds light on these questions. Missionary theologians like Robin Boyd, William Barclay, and John Webster were aware of local theological works and found in Indian Christian theology a familiarity with their personal ideas and vocabulary. A sense of familiarity created the impression that Indian Christian theologies were vernacular expressions of their Western concepts. Boyd laments this perceived state of affairs in his 1969 dissertation on Indian Christian theology. The question of whether Boyd and his compatriots had understood Indian theology on its own terms was yet to emerge as a necessary query. Rather, the conventional wisdom of the day understood Indian Christianity as an echo of missionary expressions. Capturing the popular point of view, Boyd writes:

There is no doubt that to an outside observer the Church in India seems to be dominated by Western attitudes and modes of thought. In church architecture, church organization, church services, church music and church publications, Western forms and attitudes still seem to predominate. ... Again, the teaching given in theological colleges throughout India has been, and still is, dominated by Western theology, as a glance at any syllabus will show. The result is that the preaching of the average Indian minister or evangelist reflects the Western theological categories in which he has been trained. ${ }^{127}$

Western categories did not influence Indian Christianity exclusively. Sanskrit motifs and upper-caste Hinduism also shaped Indian Christian works in English. In the nineteenth and twentieth centuries, many of the pioneers of Indian Christian thoughts were upper-caste Hindu converts or Hindu reformers like Krishna Mohan Banerjee (1813-1885), Pandita Ramabai (1858-1922), Brahmabandhab Upadhyay (1861-1907), Keshub Chandra Sen (1838-1884), and A. J. Appasamy (1848-1926). Their influence led to what Arvind Nirmal has called a Brahmanic turn in Indian Christian theology. Nirmal explains:

Broadly speaking, Indian Christian theology in the past has tried to work out its theological systems in terms of either advaita Vedanta or vishishta advaita. Most of the contributions of Indian Christian theology in the past came from caste converts to Christianity. The result has been that Indian Christian theology has perpetuated within itself what I prefer to call the 'Brahmanic' tradition. . . . To speak in terms of traditional Indian categories, Indian Christian theology, following the Brahmanic tradition, has trodden the jnana marga, the bhakti marga and the karma marga. In Brahma Bandhav Upadhyay, we have a brilliant theologian who attempted a synthesis of Sankara's Advaita Vedanta with 
Christian theology. In Bishop A.J. Appasamy, we have a bhakti marga theologian who tried to synthesize Ramanuja's Vashishtha Advaita with Christian Theology. In M.M. Thomas we have a theologian who has contributed to theological anthropology at the international level and who laid the foundation for a more active theological involvement in India - the karma marga. In Chenchiah we find an attempt to synthesize Christian theology with Sri Aurobindo's 'Integral Yoga'. ${ }^{128}$

Banerjee, who joined the Church of England post-conversion and was an ordained minister and professor at Bishop's College in Calcutta, interpreted Christ as the true prajappati (Lord and Creator) and the true purus (both human and divine). ${ }^{129}$ Ramabai came from a Maratha Brahmin family and post-conversion tried to combine her Hindu upbringing with her experience of the Holy Spirit. ${ }^{130}$ The influence of Sanskrit and the Vedas was not new to nineteenth and twentieth century Indian Christian thought. Roberto de Nobili (1577-1656) learned Tamil and Sanskrit, adopted the life of a sanyāsi, tried to establish a seminary with Sanskrit as the medium of instruction, and experimented with Sanskrit as a liturgical language in the church. ${ }^{131}$ Other followed in his enculturated footsteps. Evaluations of Indian Christian thought by Hindi authors have faulted it in both its Westernized and Sanskritic content. ${ }^{132}$

Hindi Christian literature is neither Brahmanic in construct nor Vedantic in content. It reflects a general distaste for Sanskritic ideas and idioms. It embraces a commitment to economic development, social mobility, and the abolition of caste- and gender-based discriminations. The demography of Hindi Christianity - made up mostly by Dalits, tribal, and rural converts ${ }^{133}-$ partly explains this outcome. Hindu reformers of the nineteenth century wanted to identify ideas like love, equality, and grace as shared motifs with Hinduism in their quest to reform caste practices and gender relations. M. M. Thomas, V. S. Azariah, and Paul D. Devanandan spoke for many Christians in newly-Independent India when they invited church communities to dedicate themselves to nation building, interfaith harmony, and close alliances with civil society. S. J. Samartha (1920-2001), George M. Soares Prabhu (1929-1995), Dhyanchand Carr (1938-), Renthy Keitzar (1936-2000), Aruna Gnanadason (1949-), Monica Jyotsna Melanchthon (1962-), and James Massey (1943-), among others, have produced works that address the needs of church and society, tribal issues, inter-religious dialogue, gender empowerment, ecumenism, Dalit rights, and ecological care. ${ }^{134}$ Hindi Christian authors have been cautious in their engagement of Brahmanic and upper-case ideas.

Debates over the religious meaning of 'Hindi' have shaped the development of Hindi Christian ideas in the context of Hinduism and India. The term's reference to a language was not an issue. Rather, the controversy centered on whether 'Hindi' meant 'Hindu' or 'Indian' when used by Christian authors writing in Hindi. The question played out in the editorial decision 


\section{Politics of religion}

over the Hindi title of a translated book. The story unfolds in C.W. David's introduction to Boyd's An Introduction to Indian Christian Theology in 1976 and his subsequent introduction to Benjamin Khan's Bìsvìm Satābdì ke Pramukh Dharmavijñānī ("Major Christian Theologians of the Twentieth Century") in 1990. In the 1970s, David was the editor-in-chief of the Hindi Theological Literature Committee, Khan a prominent Hindi Christian author, and Boyd a well-respected scholar of Christianity in India. David sparked the conversation when he decided to change the title of the Hindi version of Boyd's book to "Christian Theology in India" instead of maintaining Boyd's original "An Introduction to Indian Christian theology." Explaining his decision, David wrote: "There can be no such thing as Indian Christian theology" because "Christ is universal, beyond every nation." 135 That Christ was universal, however, was not the only argument against describing Boyd's book as a study of Indian Christian theology rather than as a study of Christian theology in India. David preferred a particular feature of Boyd's work and wanted to promote that feature as the core "Indian" aspect of Indian Christian thought.

Two strands dominate Boyd's account of Indian Christianity. One strand focuses on Hindu contributions to the development of Christian thought in India. Boyd draws upon a number of Hindu reformers to explain the content of Indian Christianity and his study is colored by interactions between upper-caste Hindu converts and reformers and emerging Indian Christian scholarship. Boyd's reliance on Hindu-Christian encounters to introduce Indian Christianity gave the impression that Indian Christian thought was, generally speaking, Hindu Christian thought. To balance a reliance on Hindu modes of thinking, Boyd explained Indian Christian thought as the "search for truth" intrinsic to India's religiosity and not specific to any one religious tradition. To tangle with truth was at the heart of "true religious enquiry." In the artful Hindi translation of Boyd's argument, what made Indian Christianity Indian was a Christian's "saty ke sāth ulajhnā" ("struggling with truth"), where the truth is Christ. Boyd reminded his readers that the idea of struggling with or searching for truth was a domestic idea, with a rich history, and transcended religions. "To tangle with truth, which is the demand of true religious enquiry, is not a foreign idea for the Indian tradition." 136

Indian Christian thought is made Indian by its search for truth/Truth. Locating the search for truth at the heart of Christian thought made it truly Indian. Such a Christianity would embrace ethics, engage philosophy, avoid repeating Hindu thoughts, and save Indian Christian thought from merely parroting Western works. "In India today," Boyd explained,

there is the need for a conduct-based, witness-giving theology. . . . It seems that before becoming the congregation's systematic theology or Indian doctrines it is important to tangle with the Christian revelation 
and biblical witness in order to understand their internal meaning and structure. ${ }^{137}$

David sought to promote the struggle for truth in Boyd's account of Indian Christianity and wanted to minimize Boyd's dependence on Hindu thought. To this end, David renames Boyd's work as 'Christian theology in India.' "The author," David explains, "has provided a 'definition of Indian Christian theology' in the thirteenth chapter of the book. We accept 'Indian Christian theology' in that sense." 138

Other Hindi Christian authors picked up on David's discomfort with characterizing Boyd's work as an accurate depiction of Indian Christian thinking. Benjamin Khan uses theologies in English by Western authors of the twentieth century to introduce Western Christian thoughts to Hindi readers. Khan's methodology stands in contrast with Boyd's. Boyd used theologies in English influenced by Hindu-Christian debates to characterize Indian Christian thought. Khan's book is aimed at a broad Hindi Christian audience: seminarians, pastors, educators, authors, and general readers. $\mathrm{He}$ was motivated by a lack of good Christian sources available in Hindi. Khan explained,

Many readers who go to seminary to study religion are maybe not competent enough in English to fully understand those books on Christianliterature that are written in English. In the same way, an average Christian also remains ignorant about schools of thought in Christian literature beyond the Bible because he does not have available in the mother tongue any book whose study allows him to learn about the primary schools of thought in Christian theology. I have been feeling this void for a very long time. ${ }^{139}$

Khan clarifies his intention to introduce Hindi readers to Western Christian thought in simple terms accessible to a general reader. "As far as language in concerned," he further writes, "I have tried to present the thoughts in very simple language." 140 Clarity regarding his task and sources allows David to encourage his readers to find new ways to present Christian theology in terms of India's context. He invites his readers to "think anew in the cultural context of India and to present Christian theology in terms of the religion and ethics here [in India's context]."141

"Indian theology" - a term Khan uses in Bīsvīm Śatābdī ke Pramukh Dharmavijina $\bar{a} \bar{\imath}$ in 1990 - should introduce the incarnated, risen Christ in ways that makes sense to the developing world. "Jesus Christ," Khan argues,

is this Word of God who incarnated, who united humans with God in his life, death, and resurrection. Such a presentation of this Christ is necessary that can be acceptable to today's human, who wants to be 
self-reliant on the basis of her intelligence and advances in science and who has attained maturity. ${ }^{142}$

Khan finds Boyd's work lacking in its presentation of Indian (Christian) theology. He explains:

We have studied Boyd's 'Indian Christian theology.' At the same time, some works and a book have also been published on Dalit theology. It is our humble belief that writing Indian Christian theology in English can only lead to the false use of Indian categories of thought. It is our hope that in the near future Indian scholars and thinkers will emerge who will write systematic theologies that could be truly called Christian theologies. ${ }^{143}$

Khan's review of Boyd is harsh. It claims a schism between the English language and Indian thought that is rather hard to defend. Nevertheless, Khan's comments clarify the debate on the meaning of 'Christian' in Hindi Christian sources. The Hindu tinge of Boyd's Indian Christianity can be explained as a function of the paucity of Indian Christian sources that avoid Hindu categories. It is less a function of Boyd's methodology. Boyd's selection of Indian Christian sources takes him to the Hindu worldview. David and Khan find Boyd's portrayal of 'Indian Christian' thought problematic for different but overlapping reasons. Their discomfort is symbolic of the general suspicion with which Hindi Christian authors approach Indian Christian scholarship. The desire to Indianize and Hindify Christian claims without Hinduizing them is driving this suspicion.

\section{Notes}

1 What follows is found in Carey's 'Journal' and all quotes are from the original copy of the Journal held under copyright at the Angus Library, Regent's Park College, University of Oxford. Quotations are used with the permission of the Angus Library and Archive, Regent's Park College. The 'Journal' is also transcribed in the Memoir of William Carey by his nephew, Eustace Carey.

2 The work in Serampore depended on local clerks and assistants. Munshis and missionaries were not equals. Missionaries were sabib ("master") and munshis servants. For a study of mumśsis and their sähibs, see Das, Sahibs and Munshis (1978).

3 Carey's 'Journal,' 11-12. A note on the Journal's front page reads: "A Journal kept by Mr. Carey from June 1793 (the time of his leaving Europe) to June 1975, with a Letter to Mr. Pearce in Oct. 1795."

4 Jonathan, Biśap, 71: "[Śrì krssna kānt] ek acche vidvān, ucc koți ke räjanìtijñ aur rāsțtrìy ekīkaran evam sāmpradāyik samanvay kì kāmanā karne vāle netā haim."

English translations and transliterations of Devanāgarī Hindi are mine, unless noted otherwise. Proper nouns are reproduced following common usage or published forms. As readers may lack access to Hindi source materials, the book includes English transliterations of all Hindi quotations. Translations attend to context and intent. As a result, in some cases the translations are not literal in nature. As an instance, bolo literally means 'say' (imperative). In the context of 
Hindi Christian hymns, however, bolo is better translated as 'sing,' as in 'sing praise' rather than 'say praise.'

5 Jonathan, Biśap, 71: "Masīhì samāj aur masīhì aguve sarvādhik prabuddh haim. [Mānanīy rājyapāl kā āgrah thā ki] sab prakār kā masīhì śubh samācār pracāry kāry aur dharmparivartan svecchā se kam se kam pacās varșoin ke liye band kar diyā jāe."

6 Jonathan, Biśap, 71: "Śubh samācār pracār kā arth kyā hai? Kyā yah parameśvar ke prem ko dīsromi ke sāth bämintnā hai?"

7 Jonathan, Biśap, 71: “Kyā hamne un logoin ko, jo kalīsiyā ke bāhar haim, galat sanket die haim?"

8 Bauman, Pentecostals, Proselytization, and Anti-Christian Violence.

9 Hasan, "The Myth of Unity," 185-186.

10 Fox, "Hindu Nationalism," 67-68.

11 Fox, "Hindu Nationalism," 71-72.

12 King, One Language, Two Scripts, 127-128, 144-145.

13 Pandey, The Construction of Communalism, 216-217.

14 Khalidi, "Hinduising India."

15 Raghavendra, The Politics of Hindi Cinema, xxvii-xxviii.

16 Doniger, The Hindus, 106-107.

17 Truschke, Culture of Encounters.

18 Orsini, Before the Divide; Hakala, Negotiating Languages.

19 They include, outside of India, Arun W. Jones (Dan and Lillian Hankey Associate Professor of World Evangelism, Candler/Emory) and Timothy C. Tennent (President, Asbury Theological Seminary). In India, key scholars who have engaged Hindi Christian materials include John H. Anand (Editor, Hindi Theological Literature Committee), Ravi Tiwari (Registrar, Senate of Serampore), and Din Dayal (Former Moderator, Church of North India).

20 Shukla, Hindī Sāhity kā Itihās and Hawley, Three Bhakti Voices.

21 Hawley and Juergensmeyer, Songs of the Saints of India; Hawley, Three Bhakti Voices; Thiel-Horstmann, Bhakti in Current Research, 1979-1982; Horstmann, Bhakti in Current Research, 2001-2003; Hopkins, Singing the Body of God; Malik, Hindi Poetry Today; Schomer, Mahadevi Varma; Schomer and McLeod, The Sant Tradition of India; and Hansen, Grounds for Play. Catalogues of Hindi literature are also available, from Blumhardt's colonial-era Catalogues of the Hindi, Panjabi, Sindhi, and Pushtu Printed Books in the Library of the British Museum (1893) to McGregor's Hindi Literature of the Nineteenth and Early Twentieth Centuries (1974).

22 Dandekar, The Subhedar's Son; and ibid., "Pilgrimage, Authority and Subversion."

23 This is not an exhaustive list but it captures the major types of Hindi Christian works.

24 Tiwari, Hindī Bhāssā kà Udgam, 104ff.

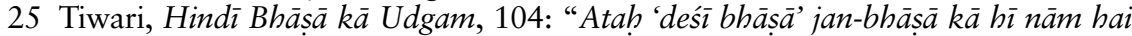
aur jis kāl evam sthān meì jo bhāsā is pad par āsin rahī, vah is nām se abhibit huī."

26 Tiwari, Hindī Bhāṣā kā Udgam, 135.

27 Van der Veer, Religious Nationalism, 170.

28 Masica, The Indo-Aryan Languages, 27.

29 Quoted in Singh, Hindi Bhāṣā, 21.

30 Masica, The Indo-Aryan Languages, 50-51.

31 For what follows, see Chatterji, Indo-Aryan and Hindi, 6-28, 156-197.

32 Flood, An Introduction to Hinduism, 33-34.

33 McGregor, "The Rise of Standard Hindi," 115-117, 131.

34 Chatterji, Indo-Aryan and Hindi, 131-154. 
35 McGregor, “The Progress of Hindi," 913-914, 945-948. See also Orsini, Before the Divide, 7.

36 Van der Veer, Religious Nationalism, 166.

37 Tiwari, Hindī Bhāṣā kā Udgam, 147.

38 For instance, see Pollock, The Language of the Gods.

39 Monier-Williams, A Sanskrit-English Dictionary, 493.

40 Tiwari, Hindī Bhāṣā kā Udgam, 440.

41 Masica, The Indo-Aryan Languages, 27.

42 McGregor, The Oxford Hindi-English Dictionary, vii.

43 Dalmia, The Nationalization of Hindu Traditions.

44 Orsini, Before the Divide; Shackle and Snell, Hindi and Urdu since 1800; Hakala, Negotiating Languages.

45 Dalmia, The Nationalization of Hindu Traditions.

46 Orsini, The Hindi Public Sphere 1920-1940.

47 McGregor, "The Progress of Hindi," 913.

48 www.censusindia.gov.in/Census_Data_2001/Census_Data_Online/Language/ Statement1.htm. India's national population in 2001 stood at 1.028 billion (www.censusindia.gov.in/Census_Data_2001/). Data from the 2011 Census has not been released yet.

49 Studies of vernacular Christian materials in cognate languages like Awadhī will further enrich this study of Hindi Christian literature, but such studies are beyond the scope of this work.

50 Office of the Registrar, "Statement-1: Abstract of Speakers' Strength," 6.

51 Office of the Registrar, "Part-1: Distribution of the 22 Scheduled Languages," 24.

52 Office of the Registrar, "Statement-7: Growth of Scheduled Languages," 16.

53 Office of the Registrar, "Statement-5: Comparative Speakers' Strength," 18.

54 KPMG, "Indian Languages," 7.

55 KPMG, "Indian Languages," 2.

56 Christopher Shackle and Rupert Snell identify the area across North India from Rajasthan to Bihar as the 'Hindi area.' Shackle and Snell, Hindu and Urdu Since $1800,13$.

57 Masica has a similar, if dated, map: he places the Union Territory of Delhi and the Indian states of Uttar Pradesh, Bihar, Madhya Pradesh, Rajasthan, Haryana, and Himachal Pradesh in the 'Hindi area.' Masica, The Indo-Aryan Languages, 9.

58 Ethnographic and textual data from field research in 2010-2011, partly funded by the South Asia Institute at Harvard, covered central and north Indian collections, including those at the Hindi Theological Literature Committee (Jabalpur) and Indian Society for Promoting Christian Knowledge (Delhi). I collated literature on translation history and theories concerning Hindi scriptures and conducted interviews with practitioners and scholars in Delhi, Nagpur, Jabalpur, and Damoh. A research assistant from India visited and accessed the archives of the Methodist publishing house in Lucknow and the Lutheran publishing house in Chhindwara responsible for considerable Hindi Christian literature in the region.

59 The Committee was led by Rev. Dr. John H. Anand, who served as the Committee's Editor and Publisher. Anand is an ordained priest of the Church of North India. Born of a Muslim mother and a Hindu father, both of whom were Dalits, Anand converted to Christianity under the influence of an American Methodist missionary. Formally trained in Hindi literature and theology, Anand has approximately sixty books to his credit. He has served as Editorial Secretary of both the Indian Society for the Promotion of Christian Knowledge and the Bible Society of India and as professor at Satyaniketan Theological College. Anand has translated the New Hindi Bible from the original Hebrew and Greek for the 
Bible Society of India. He has also translated the Book of Worship of the Church of North India and The Ecumenical Hindi Pavitr Bäibil (Holy Bible).

60 See, for instance, Kunnatholy, St. Thomas Christians.

61 Evans, Kaise Pāyā Muktidātā, 10-11.

62 Hooper, A Welshman in India, 162.

63 Eck, Banaras.

64 For what follows, see Dalmia, The Nationalization of Hindu Traditions.

65 Dalmia, The Nationalization of Hindu Traditions, 108.

66 Dalmia, The Nationalization of Hindu Traditions, 110.

67 Dalmia, The Nationalization of Hindu Traditions, 144.

68 Conference on Urdu and Hindi Christian Literature, 46.

$69 \mathrm{http}: / /$ scholar.harvard.edu/files/rakeshpeterdass/files/hindi_catalogue_1917.pdf.

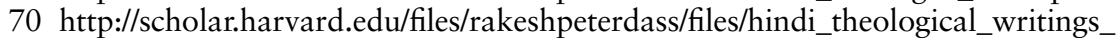
bibliography_H.T.L.C.pdf.

71 England et al., Asian Christian Theologies.

72 England et al., Asian Christian Theologies, 331-332.

73 England et al., Asian Christian Theologies, 401.

74 England et al., Asian Christian Theologies, 272-273.

75 England et al., Asian Christian Theologies, 217.

76 Amaladoss, "Foreword 1," xvi.

77 England et al., Asian Christian Theologies, xxiv.

78 Bauman and Young, Constructing Indian Christianities, xiii.

79 Sinha, Masīhī Ācaran, ii (kh): "Hindī masīhī sāhity kā durbhāgy hai ki uske pāthak bahut kam hai. ... Hindī bhāsiyom se āgrah hai ki ve jāgem aur acchī pustakom ko padhne se apnī badnāmì ko dūr karem aur prabuddh hoì."

80 Ārādhănā ke Gìt, iii: "Masīhì gìt sangrah meì vartamān bhāratìy racnāom kī kamī, kliṣt pāścāty racnāom kā ādhiky, aur saral, spaṣt aur vartamān pracalit bhāṣà kà abhāv khalne lagà thā."

$81 \bar{A} r \bar{a} d h a ̆ n \bar{a} k e$ Gìt, i.

82 Ārādhănā ke Gìt [Music Edition], iii.

83 Anand's Preface in Sinha, Masī̄ì Ā caran: "Hindī kśetrom ke thiyolāiikal kalejoin ke prinsipal, carc ke biśap, pāstar, prakāsan samsthāem, hamārī pustakoim ke vitrak, bords, miśnarī samsthāem hamārī bharsàk madad kartī haim."

84 Raj, "The Ganges, the Jordon, and the Mountain," 41.

85 San Chirico, "Between Christian and Hindu," 23-28.

86 Narayanan, “Afterword: Diverse Hindu Responses," 260.

87 Dempsey, "Lessons in Miracles from Kerala," 128-133.

88 Flood, An Introduction to Hinduism, 14.

89 Cf., Assmann, Monotheismus, 10; cited in Malinar, The Bhagavadgītā, 7, 238.

90 Malinar, The Bhagavadgitā, 7-9, 237-238.

91 Nasr, The Study Quran, 664-665.

92 Ernst, Following Muhammad, 118.

93 Lumbard, "The Quranic View of Sacred History," 1766-1769.

94 Raj and Dempsey, "Introduction," 5.

95 Raj and Dempsey, Popular Christianity in India; Young, India and the Indianness of Christianity; Bauman and Young, Constructing Indian Christianities.

96 Mosse, The Saint in the Banyan Tree, 27-28, 284.

97 Bowen, Religion in Practice, 125.

98 Hawley and Juergensmeyer, Songs of the Saints, 7.

99 Eck, Darśan, 16.

100 Schelling, The Oxford Anthology of Bhakti Literature, xvi.

101 Monier-Williams, A Sanskrit-English Dictionary, 743. For the dates, see Doniger, The Hindus, 693. 
102 Lipner, The Face of Truth, 112-115; Bartley, The Theology of Rāmānuja, 78-79.

103 Bartley, The Theology of Ràmānuja, 79.

104 Schelling, The Oxford Anthology of Bhakti Literature, xvii-xix.

105 Kulandran, "Christian Faith and Hindu Bhakti," 118-121.

106 Hawley, Three Bhakti Voices, 105. Translated by Hawley.

107 Scott, "Hindu and Christian Bhakti," 12.

108 Scott, "Hindu and Christian Bhakti," 21-22.

109 Schelling, The Oxford Anthology of Bhakti Literature, xiv.

110 Chakrabarty, Provincializing Europe, 231-232 and Raychaudhuri, Europe Reconsidered, 88-89, cited in Pinch, "Bhakti and the British Empire," 167.

111 Pinch, "Bhakti and the British Empire," 176-177.

112 Pinch, "Bhakti and the British Empire," 178-179.

113 Jones, Missionary Christianity, xx-xxi.

114 Jones, Missionary Christianity, 8-16.

115 Jones, Missionary Christianity, 275.

116 Hymn numbers are from Ārādhănā ke Gìt.

117 Ārādhănā ke Gìt, “Topical Index,” 1.

118 McGregor, The Oxford Hindi-English Dictionary, 1069.

119 For an analysis of the interplay of bhakti motifs and social hierarchies in Tamil Christian hymns, see Israel, Religious Transactions in Colonial South India (2011). Israel's work on Tamil hymns is also summarized in a 2014 article, "Authority, Patronage and Customary Practices."

120 'Holy Spirit' is the typical Hindi translation of pavitr àtmā.

121 McGregor, The Oxford Hindi-English Dictionary, 623.

122 Hawley and Juergensmeyer, Songs of the Saints of India; Hawley, Three Bhakti Voices.

123 Hawley and Juergensmeyer, Songs of the Saints, 42-45.

124 Nirguna forms of devotion address God without qualities, form, or attributes (from nir-guna, without qualities or attributes). Saguna bhakti is directed to God with attributes and qualities (from sa-guna, with qualities or attributes).

125 Hawley and Juergensmeyer, Songs of the Saints, 44-47.

126 Hawley and Juergensmeyer, Songs of the Saints, 129.

127 Boyd, An Introduction to Indian Christian Theology, 1-2.

128 Nirmal in Massey, Indigenous Peoples, Dalits, 215. To note, by “caste converts" Nirmal means upper caste converts.

129 Banerjee, The Relation Between Christianity and Hinduism, cited in England et al., Asian Christian Theologies, 211-212.

130 Ramabai, A Testimony, cited in England et al., Asian Christian Theologies, 212-213.

131 Rajamanickam, Roberto de Nobili on Adaptation and Arokiasamy, Dharma, Hind $u$ and Christian, in England et al., Asian Christian Theologies, 206-207.

132 Thomas, "Introduction," v.

133 See, Clarke, Dalits and Christianity and Massey, Dalits in India.

134 England et al., Asian Christian Theologies, 189-192.

135 David's preface in Boyd, Bhārat meim Masīhi Dharmavijūān, ix: "Bhāratīy khristīy dharmavijūān jaisì koī cìz nahìm ho saktī [kyomki] kbrist sarvalaukik hai, kisī bhī rāṣtr se pare hai."

136 Boyd, Bhārat meim Masīhi Dharmavijūān, 162: "Saty ke sāth ulajhnā, jo sacī dharmasaiddhāntikī kì māing hai, bhāratīy paramparā ke liye videśí bāt nahìì hai."

137 Boyd, Bhārat meì Masīhī Dharmavijūān, 163: "Bhārat meì āj vyāvahārik, sākșì dene vāle dharmavijãān kī āvaśyakatā hai . . Esā pratìt hotā hai ki kalìsiyà kà vyavavastit dharmavijāān athavā bhāratīy viśvāskathan banne ke 
pable yah āvaśyak hai ki khristīy prakāśan aur bāibalī sākșy se uljhā jāe tāki unke āntarik arth aur āntarik samracanā ko samjhà jā sake."

138 David's preface in Boyd, Bhārat mem Masīhī Dharmavijñān, ix: "Lekhak ne pustak ke terhavem addhyāy mem 'bhāratīy khristīy dharmavijñān kī paribhāṣā' dī hai. Us arth meì ham 'bhāratīy khristīy dharmavij̄ñān' ko svīkār karte haim."

139 Khan, Bìsvìm Śatābdī ke Pramukh Dharmavijñānī, xi: "Bahut se pāthak jo semanari meì dharm adbyayan ke liye jāte haim ve śāyad amgrezī bhāṣā

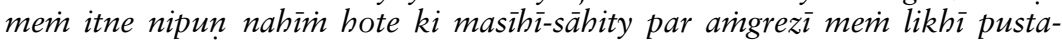
koì kā pūrī samajh ke sāth adbyayan kar sakem. Isī prakār sādhāran masīhī bhī bāibal ke atirikt any masīhī sāhity kì vicārdhārāom se anabhijũ rahtā hai kyomki use mātrbhāșā mein koī eisī pustak upalabdh nabìm jis ke adhyayan se vah masīhi dharmavijñān kī pramukh vicārdhārāom ko paḍ sake. Is riktatā ko maim kāfì lambe samay se mahasūs kar rahā thā."

140 Khan, Bìsvìm Śatābdī ke Pramukh Dharmavijūānī, xii: "Bhāṣā kā jahāim tak sambandh hai, maimne vicārom ko bahut saral bhāṣa mem vyakt karne kā prayās kiyā hai."

141 David's preface in Khan, Bīsvìm Śatābdī ke Pramukh Dharmavijūānī, ix: "[P]reraña bhī prāpt hoḡ̄ ki ve bhārat ke samskrtik pariveś memi nayā cintan karem aur yahāim ke dharm aur karm siddhänt kì vicār koțiyom meì masīhì dharmavijñān ko prastut bhī karem."

142 Khan, Bīsvìm Śatābdī ke Pramukh Dharmavijūānī, 211: "Yah ìsvar kā śabd yīś masīh hai jo dehadhāri huā, jisne apne jīvan, mrtyu aur punarutthān meì manuśy kā ìśvar se milāp karāyā. Is masīh ka eisā prastutikaran āvaśyak hai jo āj ke manuśy ko, jo apnī buddhi aur vijñān kī naì naì khojom ko dvārā ātm nirbhar honā cāhtā hai aur paripakv avasthā ko prāpt kar cukā hai, māny ho."

143 Khan, Bīsvīin Śatābdì ke Pramukh Dharmavijñānī, 213-214: "Hamne bāuyad $k e$ granth 'indiyan kriściyan thiyāuloji' $k \bar{a}$ adbyayan kiyā. Idhar dalit dharmavijāān par bhī kucch lekh aur ek pustak prakāsit hū hai. Hamārī vinamr mānyatā hai ki amgrezī meì bhāratīy khristīy dharmavijūān likhne meim bhāratīy vicār kotiym kā jūthā prayog hì ho saktā hai. Hamārì āsá hai ki nikat bhaviṣy meì b̆hāratīy vidvān evam cintak paidā hoinge jo vyavasthit dharmavijūān likheminge jise vāstav mein masīhì dharmavijñān kahā jā sakegā."

1 For this paragraph, I rely on Doniger, The Hindus.

2 For the edict's languages, see Thapar, Reading History from Inscriptions.

3 Shackle and Snell, Hindi and Urdu Since 1800.

4 McGregor, "The Rise of Standard Hindi," 114.

5 Aquil, The Muslim Question, 1, 2, 133-136. See also Eaton, "Sufi Folk Literature," 120-121.

6 Thapar, The Penguin History of Early India, 470; Aquil, The Muslim Question, 134-135.

7 Orsini, "Introduction," 3.

8 Guha, India After Gandhi, 130.

9 Guha, India After Gandhi, 128, 189-208.

10 Nehru, The Unity of India, 244.

11 Collected Works, "National Language" (Young India, 10-2-1927), 38:104.

12 Collected Works, "Note to Amritlal T. Nanavati" (On or before July 5, 1946), 91:241.

13 Urdu script uses a modified form of Arabic that includes additional letters that represent sounds exclusive to Persian and/or Urdu. Naim, Introductory Urdu, 15.

14 Collected Works, "Hindi + Urdu = Hindustani" (Harijan, 8-2-1942), 81:486.

15 Collected Works, "Hindustani, Hindi and Urdu" (Harijan, 29-10-1938), 74:126.

16 Nehru, The Unity of India, 247. 
17 Orsini, The Hindi Public Sphere 1920-1940.

18 Guha, India After Gandhi, 192.

19 Collected Works, "Hindi + Urdu = Hindustani" (Harijan, 8-2-1942), 81:486.

20 Guha, India After Gandhi, 394.

21 Keay, A History of Hindi Literature, 8-9.

22 Guha, India After Gandhi, 1.

23 Guha, India After Gandhi, 8-9.

24 Recent projects include a ten-volume Pastors Pulpit Bible Commentary in Hindi in 2011-2014. I advised the Editorial Board of the Pastors Pulpit Bible Commentary series. In 2010, the second edition of The Oxford Hindi Dictionary of the Christian Church was printed. This is the official Hindi translation of The Oxford Dictionary of the Christian Church (ed. F.L. Cross and E.A. Livingstone) under license from Oxford University Press.

25 www.ntcdoon.org/index.php/publications

26 For instance, see Sugirtharajah, Asian Faces of Jesus, and Chhungi. Theologizing Tribal Heritage.

27 Dongre, Prem Iśvarīy (1960); Chauhan, Viśvās Catțān (1962); Yesudas, Krpāa Mārg (1965); Zahir, Svarg aur Uske Uparānt (1968); Lall, Susamācār-Pracār (1970); Khan, Sacchī Śānti (1971); Singh, Masīhī Ādhyātmik Śikṣā (1975); and, Dayal, Masīhī Dharm Vijñān (2005).

28 Bishop Dayal was born in 1925 in a Christian family in north India (Uttar Pradesh). He received his Bachelor of Arts from Allahabad University in 1949 and a Bachelor of Divinity from Leonard Theological College, Jabalpur, in 1952. He was ordained in 1953. He served as Chaplain at the Allahabad Agricultural Institute and was missionary in South Africa from 1955-1964. He completed a Master of Theology from Pittsburgh Seminary in 1965 and served as pastor in India from 1965-1970. In 1970, he was elected Moderator of the North India Synod of the United Church of Northern India, a founding member of the Church of North India. Dayal served as Bishop of the Lucknow Diocese, Deputy Moderator, and Moderator of the Church of North India. He retired in 1990.

29 Dayal, Masīì Dharm Vijūān, 148-149.

30 Dayal, Masīī Dharm Vijũàn, 144. For an excellent history of the formula of Chalcedon, see Chadwick, The Early Church, especially 200-212. For the text of the Chalcedonian statement, see Hardy, Christology of the Later Fathers, 371-374.

31 Dayal, Masīhī Dharm Vijñān, 142.

32 Dayal, Masīhī Dharm Vijñān, 170: [S]rșți, uddhār aur antim samāpan ke siddhānt ek dūsre se jude hue haim.

33 Dayal, Masīhī Dharm Vijñān, 3-4. "Yadì dharm vijñān ek prakār kā vijñān hai to vijūān ke samān usme spaștā honī chāhie, aur uskī vyākhyā me sāmañjasyatā aur vyāpakatā āvashyak hai."

34 Dayal, Masīīi Dharm Vijūān, 31.

35 Dayal, Masīhī Dharm Vijũān, 148-149.

36 Mahendra earned degrees in social science, theology, translation, divinity, and Hindi. He has translated five books into Hindi - on interreligious relations, history of the Indian church, prayer, and the ecumenical movement - and managed Jivan Darpan ("Life Mirror"), a Christian radio program, from 2002 to 2004. Biography from Mahendra, Masīh Merī Manzil, 70-73.

37 Mahendra, Masīh Merī Manzil, xv-xvii: “Masīh Merī Manzil ke prakāśan kā avasar atyant mahattvapūrn hai. Yah masīhī viśvās aur sevakāī mei் mere 12 varș pūre karne ke ānand, dhanyavād aur ābhār kī abbivyakti ko darśātā hai. Yah mere abhiṣek (ārdineśan) ko bhī cinhit kartā hai. Iske sāth hī, mere ab tak ke safar meì param pitā parameśvar kī asìm krupā, prem, anugrah, kșamā, 
āsiș, dekhbhāl aur satat protsāhan kī gavāhī bhī detā hai. . . . Merī àșā aur prärthanā hai ki prastut kavìtā-sañgrah masīhī bahno-bhāiyo ke lie, viśeșakar unke lie jo viśvās mein nae hai, protsāhan kā kāran hogā aur prabhu parameśvar kī mahimā ke lie upayogī siddh hogā."

38 Mahendra, Masīh Merī Manzil, 25, 30.

39 Mahendra, Masīh Merī Manzil, 55-56.

40 Mahendra, Masīh Merī Manzil, 38-39.

41 Frykenberg, Christianity in India, 458.

42 Fernando and Gispert-Sauch, Christianity in India, 239-242.

43 Anand, O Mrtyu!

44 Komal Masih was born in Uttar Pradesh. He earned a Bachelor of Divinity and Master of Theology from Leonard Theological College, Jabalpur, in 1960. After serving as a parish priest for two years in the Methodist Church of India, he joined as professor the Bareilly Theological Seminary (1962-1965) and North India Theological College (1967-1976). He obtained a Master of Sacred Theology degree from Wesley Theological Seminary in Washington, DC (1965-1967). He then served as District Superintendent of the Muradabad Conference of the Methodist Church, and from 1981-82 as Vice-President of the Hindi Theological Literature Committee.

Christopher B. Peter was also born in Uttar Pradesh. He completed a Bachelor of Theology from North India Theological College in 1973 and completed a Bachelor of Divinity from Leonard Theological College in 1975. He was ordained a pastor of the Methodist Church in 1974. From 1976-1979, he taught the Old Testament at North India Theological College. He earned a Master of Theology in 1981 from United Theological College, Bangalore and rejoined North India Theological College as a professor in 1981.

45 Masih and Peter, Prabhu Yeśu kī Jìvanī aur Sevākāry, 9: "Yìśu ke jīvan evam sevā kāry ke sambandh mein sabse mahatvapūrn khristīy srot haim (mattī, markus, lükā aur yūhannā)."

46 Masih and Peter, Prabbu Yeśs kī Jìvanī aur Sevākāry, 3.

47 Masih and Peter, Prabhu Yeśu kī Jìvanī aur Sevākāry, 19.

48 Frei, The Identity of Jesus Christ, 5. Emphasis added.

49 Frei, The Identity of Jesus Christ, 12.

50 Frei, The Identity of Jesus Christ, 95.

51 Thiemann, Revelation and Theology, 90.

52 Masih and Peter, Prabhu Yeśu kī Jìvanì aur Sevākāry, 133-134: "Yìsu ke drșțān-

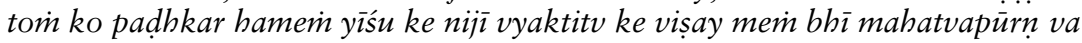
rocak jānkārì miltī hai."

53 Masih and Peter, Prabhu Yeśu kī Jìvanī aur Sevākāry, 133: "Sencurī dikśanarī ke anusār dṛștānt ek aisī kathā hai, jo sac ho saktī hai aur jo kisī naitik saty kī śikshà dene ke lie bolì jāi."

54 Arya was a research assistant in India's Ministry of Education, Assistant Director at the Bureau of Indian Standards, and a Joint Director at India's Home Ministry. She has published 11 Hindi books on education, science and technology, handicrafts, and stories of the Bible. She was awarded the Hindi Millennium Award for her various contributions to Hindi literature. (Biography from Arya, Kavitā meì Śubh Sandeś)

55 Ārādhănā ke Gīt, Number 70.

56 Ārādhănā ke Gìt, Number 310.

57 Ārādhănā ke Gìt, Number 311.

58 For the order, see note 36.

59 In An Intermediate Greek-English Lexicon (798), Liddell and Scott note that teleou can represent both "to complete" and "to pay what one owes." 
60 Anand, Śubb Śukravār ki Ārādhănā, 45: "Sab prakār ke pāp bhī parameśvar ke prati hamārā karj haim. Parameśvar hamem tab tak svīkār nahīm kar saktā jab tak yah karj cuktā nahīin ho jātā."

61 Anand, Śubh Śukravār ki Ārādhănā, 47: "Kyā pūrā huā? Kyā samāpt huā? Pāp ke viruddh yuddh, burā̄i ke viruddh yuddh. Parameśvar se hamārā sambandh punah sthāpit huā."

62 Sona, Antim Sāt Vacan, 54-55.

63 Prasad, Krūs kā Bhed, 24: "Nahìm, prabhu jūuthakar apne pitā ke pās svarg mein uske dāhine hāth baithā mere aur āpke liye kāry kar rahā hai."

64 Khan, Māno Yā Na Māno, xiii: "Maimne yīśu masīh ke jīvan kī is kahānī ko likhne meì sant yūhannā dvārā racit susamācār ke mārg par calā hūim. Kyomki . . cauthā susamācār yīśu masīh ke jìvan kā ek viśāl citr prastut kartā hai jismei் hum keval bāhy ghațanāom ko silsilevār hì nahīin dekhte varan uddhārkartā yīśu masīh ke citr ke āntarik rūp kì pratyek kadì ko āpas mein jude hue dekhte haim. Aur yah susamācār any susamācārom kì ghațanāom meì jo darāremi dikhāì detī haim unkī pūrti kartā hai."

65 Khan, Māno Yā Na Māno, 52: "Parameśvar ke rājy kī āśā yahūdì dharm kā hrday thī aur purāne niyam kì śikșā kā kendr bindu."

66 Khan, Māno Yā Na Māno, 53: “Ek sāmāny vyakti paścāttāp kā pracār kartā buā aur baptismā kī ek nā̄ paramparā kā śubhārambh kartā huā, na keval hazārom àdmiyom ko apnī or kheminc rahā thā balki isne dhārmik netāom ko bhī majbūr kiyā ki ve patā lagāyem ki yah vyakti kaon hai?"

67 Khan, Māno Yā Na Māno, 144: "Khatrā yah thā ki unke àścaryakarm dekh aur yah jān ki āp hì àne vāle masīhā haim to ho saktā thā ki log unhem zabardastī pakad yahüdiyom kà rājā ghoṣit kar dete aur deś mein ek vidroh kī àg bhadak uthati."

68 D’Mello, İśvānì kā Sāthī, 53: "Prasād kaī sālom se sarpanc banā rahā. Uske sāsan ke samay usne kaitholikom ke yājak ko va dharmabahinom ke bahut hī satāya thā. Garīb logom ko uske prati nafrat bhī thī. Ek bār vah bahut bìmār pad gayā. Usne yah icchā prakat kī ki use śahar ke kaitholik aspatāl mem hī ilāj ke lie bhartī kiyā jāy aur any kisī aspatāl meì nahìm. Kāran pūchne par usne batāyā, "kaitholik log kisī kā pratiśodh nabìm karte, ìmāndārì se ilāj karte haim aur ve ìsā ke anuyāȳ hone ke kāran kṣamā kar dete haim."

69 D’Mello, İśvānì kà Sāthī, 91: “Sampat ìsà̄ ban gayā thā. Uske sambandhiyom ke yah acchā nabìm lagā. Ek din uske donoì bhā̄i uske yahāin āye aur bole, "tum kyomi ìsāì ban gaye ho? Hamāre dharm meì kyā kamī hai? Tumberi mālūm hai ìsā kaun the, uske mām-bāp kaun the?..." Sampat ne śānt hokar apne bhäiyom ke praśn sune aur sockar kahā, "īsāì banne ke pūrv maim durācār kartā thāa, mere bāl-bacce mujhse darte the, mere ghar meì khāne kā anāj nahìin thā, merī aurat dukhī thī . . jab se maimne ìsā ko svīkār kiyā hai, maimne dārū pīnā chod diyā hai, mere ghar mexim ab śānti hai, baccoin ko bhar-pet khānā miltā hai, ham pyār se jìte haìm. Mere lie ìsā jìvit haim. Unki śikṣā ke anusār hum jī rahe haim, ghar meì prārthanā, bhajan-kīrtan hotā hai. Hameì ìsā se nayā jīvan milā hai."

70 Khan, Khristīy Nìtiśāstr, 16-17: "Khristīy nìtiśāstr kā dharmavijūān ke sāth ghanișth sambandh hai. Do rüpom mein khristīy nìtiśāstr dharmavijñān par àdhārit hai: (1) Khristīy nìtiśāstr apnī vișay sāmagrī yīsu khrist kì jīvanī aur śikśā tathā vyaktitv se prāpt kartā hai. (2) Khristīy nìtiśāstr kā kāry yah hai ki khristīy siddhāntom yā viśvās kī naitik vyākhyā kare. Is dṛțtikon se nìtiśāstr dharmavijñān kà sevak hai. Khristīy nìtiśāstr sankkalp aur kbristī jan aur khristī samāj ke sandarbh memi khristīy viśvās-sāmagrī par vicār karatā hai."

71 Khan, Khristīy Nìtiśāstr, 65-66.

72 Khan, Khristīy Nìtiśāstr, 76.

73 Khan, Khristīy Nìtiśāstr, 165-176. 
74 Khan, Khristīy Nìtiśāstr, 170: "Paulus to keval yah dikhānā cāhtā hai ki yadi karm dvārā hì mukti hai to fir masīh kà avatarit honā aur balidān vyarth hai. Vah to jo î́var ne manuşy ke lie kiyā us par jor de rahā hai."

75 Khan, Khristīy Nìtiśāstr, 63: "Isse yah spașt hai ki parameśvar ke sivāy aur kō̄ śubh nahìm, aur parameśvar hi naitikatā kā srot evam māpadand hai."

76 Khan, Khristīy Nìtiśāstr, 159-162.

77 D’Mello, İ́svānì kā Sāthī, 3, 6, 9, 15, 67.

78 Masih and Peter, Prabhu Yeśu kī Jìvanī aur Sevākāry, 168.

79 Masih and Peter, Prabhu Yeśu kī Jìvanì aur Sevākāry, 173: "Markus racit susamācār kā yīśu hamāre-āpke samān ek sādhāran manuṣy hai."

80 Masih and Peter, Prabhu Yeśu kī Jìvanì aur Sevākāry, 174: “Mar. 1:1 me . . yìśsu kì divyatā uske Masih kablāe jāne meì nahimi varan 'parameśvar kā putr' hone mein hai."

81 Masih and Peter, Prabhu Yeśu kī Jìvanī aur Sevākāry, 177: "Yīśu parameśvar kā putr hone ke kāran parameśvar ke sāth ädbyātmik drstikon se ek hai."

82 Masih and Peter, Prabhu Yeśu kī Jìvani aur Sevākāry, 131: "Yìsu kā daibik punarutthān to svīkāry hai parantu daibik svargārohan ko svīkār nabim kiyā jā saktā kyomki māims aur lahū parameśvar ke rājy ke adhikārī nahīin ho sakte (1 kur. 15:50). Atạp paulus ne jo siddhānt prastut kiyā hai vah adhik saraltāpürvak svīkār kiyā jā saktā hai."

83 Masih and Peter, Prabhu Yeśu kì Jìvanì aur Sevākāry, 131: "Yīśu kā sadeh punarutthān to buā parantu ek alaukik v rahasyapūrn proses ke dvārā uskī sthūl bhautik deh sūkśm ātmik deh merim parivartit ho gai. . . . Antatah sūkśm ātmik deh meim yīsu kā svargārohan huā."

84 McGregor, The Oxford Hindi-English Dictionary, 1046.

85 Masih and Peter, Prabhu Yeśu kī Jìvanī aur Sevākāry, 133-147.

86 Masih and Peter, Prabhu Yeśu kī Jìvanì aur Sevākāry, 177: "Markus racit susamācār ke anusār prabhu yīsu masīh do mahān kāry karne ke lie dehadhārī huā. Pahalā kāry hai-parameśsar ke rājy ke nikaț hone kī ghoṣaṇā (1:15) . . . Markus ke anusār masīh kā dūsrā kāry hai-chudautī."

87 Masih and Peter, Prabhu Yeśu kī Jìvanī aur Sevākāry, 138.

88 Khan, Māno Yā Na Māno, 191-192: "Parameśvar pavitr pavitr pavitr hai aur yìsu niṣppāp thā. Hamare lie pāp banā. Pāp aur pavitratā donom sāth nahìm ho

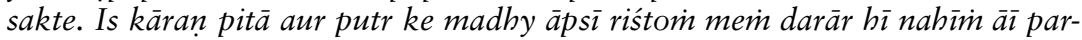
antu pitā se prọthak ho pāp kī śaktiyom se ghirā huā manusy ke uddhār ke lie apnā balidān dene ke lie yísu akelā hì krūs par lațā huā thà. Manuṣy ke pāp kī kshatipürti manușy hì de saktā thā."

89 Khan, Māno Yà Na Māno, 33.

90 Khan, Māno Yā Na Māno, 45.

91 Khan, Māno Yà Na Māno, 89-90.

92 Ārādhănā ke Gìt, Number 311.

93 Amaladoss, The Asian Jesus; Premkumar, "The Commonwealth of Dalits and Tribals."

94 D’Mello, İśvānī kā Sāthī, Story 68, 33-34: "Vah maṭ̂ūāi thā. Uskā kām maț ke dvār par jo bhī garīb madad ke lie àye uskī sahāyatā karnā thā. Ek din jaise hì vah kām ke lie nikal hī rahā thā ki issa ne use darśan diye. Use ab cunnā thā ki vah darśan meì dikhe ìsā ke sāth rahe yā garīboin kì madad ke lie kartavy par lage rahe. Usne kartavy pālan karnā cun liyā. Garīboin kī madad kar jab vah apne kamre mem lautā to amdherā ho calā thā. Jaise hì usne dīp jalāyā ìsā ā khade hue. İsā ko dekhkar vah ānand se fūlā na samāyā. İsā ne usse kahā, 'agar tum kartavy pālan ke lie nahìm nikalte to maim yahāim se calā jātā'."

95 D’Mello, Íśvānī kā Sāthī, Story 122, 60: “Naye naukar kī parīkșā ho rabì thī. Mālik ne pagà̃r dete samay das-das rupaye ke not diye aur us rakam mein das 
rupaye kā ek not adhik rakhā. Naukar ne paise gine to das rupaye kā ek not adhik niklā. Vah mālik se bolā, 'das rupaye adhik hairi. Inheì lïjie.' Mālik ne naukar kì saccāi kì praśamsā kì aur un das rupaye apne pās rakbne ko kahā.”

96 D’Mello, İśvānì kàa Sāthī, Story 178, 87: “Deś meì samyavād kī sarkār thī. İsāiyom ko dharm pālan karnà sakht manā thā. Sāinketik bhāsāa dvārā ek yājak isaìiyom se sampark kiyā karte the. Vah logom ko sūcit karte the ki ve unse kis jagah milem, jaise sarakoi் ke kināre, sāmān becte hue yā samācār patr becte. İsāi log jab unse sāmān kharīdte to ve sāmān ke sāth param-prasād rakhkar de dete. Viśvāsī us prasād ko upne ghar le jākar apne privārom mei் param-prasād svīkār karne kī vidhi racte. Jahāim cāh vahāim rāh."

97 McGregor, The Oxford Hindi-English Dictionary, 666.

1 Doniger, The Hindus; Khilnani, The Idea of India; Varshney, Battles Half Won.

2 Nandy, Time Warps, 62.

3 Guha, India After Gandhi.

4 King, One Language, Two Scripts, 173-176.

5 Nandy, Time Warps, 73-76.

6 Guha, India After Gandhi, 118.

7 Khilnani, The Idea of India.

8 Varshney, Battles Half Won.

9 See the riot database in Varshney, Ethnic Conflict and Civic Life.

10 King, One Language, Two Scripts, 15.

11 Pollock, The Language of the Gods, 11-12.

12 Cf. Pollock, The Language of the Gods, 21.

13 "Now the birth of Jesus the Messiah took place in this way. When his mother Mary had been engaged to Joseph, but before they lived together, she was found to be with child from the Holy Spirit" (NRSV).

14 Dharmăpustak kā Antbhāg, [or, The New Testament in Hindi], 2.

15 Hindì Bäibil ("Hindi Bible"), 1-2.

16 Pavitr Bāibil ("Holy Bible"), 1.

17 Cf. Allen, Ocean of Inquiry, 12.

18 Shukla, Hindī Sāhity kà Itihās, 299-301.

19 Shukla, Hindī Sāhity kā Itihās, 301; Das, Sahibs and Munshis, 18.

20 Anand, Pāścāty Vidvānoìn kā Hind̄̄ Sāhity, 78-80.

21 Kraput, "Postcolonialism," 177.

22 The London-based Society for Promoting Christian Knowledge was formed on March 8, 1698. Its missionary activities led to the formation of the Indian Society for Promoting Christian Knowledge in 1710. Under the Societies Registration Act of 1860, Indian Society for Promoting Christian Knowledge constituted itself as a self-governing body independent of the London-based Society for Promoting Christian Knowledge. On October 15, 2010, Indian Society for Promoting Christian Knowledge celebrated its tercentenary in India.

23 Textual data from field research, partly funded by the South Asia Institute at Harvard University, covered central and North Indian collections, including those at the Hindi Theological Literature Committee, the Indian Society for Promoting Christian Knowledge, and Lucknow Publishing House, a Methodist publishing house.

24 Yale Digital Library Collection, digcoll 183956, page 106.

25 Greaves and Mukerji, A Descriptive and Classified Catalogue, iii-iv.

26 The American Tract Society, Allahabad; Baptist Mission Press, Calcutta; Bengal Sunday School Union, Calcutta; Christian Literature Society, Allahabad; Christian Mission Press, Jabalpur; Canadian Presbyterian Mission Press, Rasalpur, Mhow; Calcutta Tract Society, Calcutta; Epworth League Office, Lucknow; Gossner Evangelical Lutheran Mission Press, Ranchi; Methodist Publishing 
House, Lucknow; North India Christian Tract and Book Society, Allahabad; Punjab Religious Book Society, Lahore; and the Society for the Propagation of the Gospel Mission Book Depot, Ranchi. (Greaves and Mukerji, A Descriptive and Classified Catalogue, v).

27 Ruark El Paso Herald; Ruark, Spokane Daily; and, Ruark, Winona Daily.

28 English titles as given in the 1917 catalogue. Greaves and Mukerji, Descriptive and Classified Catalogue, 17-21.

29 Sharma, Christian Missions in North India, 16.

30 Moget, Vagabonds for God, 1.

31 Tete, Constant Lievens, 13-15. See also, Mahto, Hundred Years of Christian Mission.

32 Das, Sahibs and Munshis, 154-164; Augustine, Fort William, 166-168.

33 Das, Sahibs and Munshis, ix, 112-118.

34 Das, Sahibs and Munshis, 8.

35 Mayhew, Christianity and the Government of India, 160-161. Mayhew (18781948), a Classics master at Eton in the 1920s and an educator in the Colonial Education Service, was director of Public Instruction, Central Provinces, India. An Oxford graduate, he was first assigned to Madras in India in 1903, was deputy director of Public Instruction in Madras by 1907, and by 1916, at age 38, was appointed director of Public Instruction in the Central Provinces (Whitehead, Colonial Educators, 149-153).

36 Ingleby, Missionaries, Education and India.

37 Duff, India, and India Missions, 518.

38 Duff, India, and India Missions, 519-520.

39 Sahu, The Church of North India, 9.

40 Sahu, The Church of North India, 101-103.

41 Dayal, Uttar Bhārat aur Pākistān mem Masīhī Dharm, 151.

42 Dayal, Uttar Bhārat aur Pākistān mem Masīhī Dharm, 170.

43 Tete, Constant Lievens, 2.

44 Tete, Constant Lievens, 57.

45 Different dates are claimed for the start of the Catholic church in Sardhana. Sardhana's Catholic Basilica, The Church Basilica of our Lady of Graces, lists two possible dates for the beginning of the church: 1809 and 1820 (www.sardha nachurch.org/TheChurch-Basilicaof.aspx; accessed April 10, 2015). Sharma lists the completion of the church in 1821 (Sharma, Christian Missions in North India, 58). According to Sharma, the church's beginning must have preceded 1821.

46 Moget, Vagabonds for God, 101.

47 Moget, Vagabonds for God, 49.

48 Moget, Vagabonds for God, 126.

49 Moget, Vagabonds for God, 57.

50 Hutton, Census of India, 423, cited in Webster, The Dalit Christians, 73.

51 Webster is critical of the term "mass movement," popularized by Pickett's Christian Mass Movement in India (1933), whose distinguishing features are a group decision in favor of Christianity and the "consequent preservation of the converts' social integration" (Pickett, Christian Mass Movements in India, 22). Webster argues the conversions were neither the product of group think nor did they succeed in preserving the converts' social integration. He prefers "largescale conversions" to highlight the personal choice central to the act of conversion and the converts' move from an assigned social hierarchy to a "new 'mixed' community of unclear social status" (Webster, The Dalit Christians, 45).

52 Webster, The Dalit Christians, 47.

53 Webster, The Dalit Christians, 48-50.

54 Kim, In Search of Identity, 35-36, 190-200.

55 Stewart, "In Search of Equivalence," 269-270. 
56 Compare Richard M. Eaton's 1974 study of the expansion of Indian Islam in "Sufi Folk Literature and the Expansion of Indian Islam," History of Religion, 127. Eaton contends that the Sufis of the Deccan made "no conscious effort" to gain non-Muslim followers and hence cannot be called missionaries seeking conversions akin to that of the nineteenth- and twentieth-century Christianity movement in India. He describes "conversion," which has been aligned with Christian missionary activity, as a sort of "self-conscious, sudden and total change of belief" and hence "inadequate" to describe the "process" by which Sufis of the Deccan found non-Muslim followers. Rather than a sudden conversion to Islam, these followers are "still undergoing a gradual process of Islamic acculturation" (Eaton, "Sufi Folk Literature, 127). This study of Hindi Christians questions Eaton's ascription of Christian conversion as sudden and total change. Gradual acculturation - in theology, practice, and liturgy - better explain the ongoing transformation of Hindi-language Christian communities in India.

57 Stewart, "In Search of Equivalence," 261-262.

58 Ārädhănā ke Gìt, Number 267.

59 Dharmputstak kā Antbhāg, 9-10.

60 Hindī Bāibil, 6.

61 Dharmputstak kā Antbhāg, 175.

62 Hindì Bäibil, 101-102.

63 The transition is in the concluding vowel, from gay- $\bar{a}$, baith- $\bar{a}$, (dene) lag- $\bar{a}$, and khad-a $h u-\bar{a}$ to ga-e, baith ga-e, (dene) lag-e and uth-e.

64 See, for instance, Sheth, "Hindu Avatar and Christian Incarnation."

65 Vivekananda, The Complete Works, 7:1; see also Amaladoss, The Asian Jesus, 21-24.

66 Thangaraj, The Crucified Guru, 75.

67 Amaladoss, The Asian Jesus, 117.

68 Amaladoss, The Asian Jesus, 121.

69 Mohammed, "Jesus and Krishna," 11. Mohammed, a Jesuit, is professor of systematic theology at Regis College, the Jesuit School of Theology at the University of Toronto. Mohammed has published on Ignatian spirituality and the Bhagavad Gita , Hinduism, and spirituality and on the theology of religions and interfaith hermeneutics.

70 Mohammed, "Jesus and Krishna," 22.

71 Chakkarai, Jesus the Avătār, 5-6, 48. Chakkarai (1880-1958) was from a wealthy Chettiar family in Madras. After practicing law (1908-1913) he joined the Danish Mission in Madras. Inspired by Mahatma Gandhi, in 1917 he joined the Home Rule Movement. He was a theologian and wrote Jesus the Avătār and The Cross and Indian Thought. He was also an influential public figure and was elected mayor of Madras (1941), chairman of the All-India Trade Union Congress (1951), and member of the Legislative Council (1954) (England et al., Asian Christian Theologies, 224-225).

72 Boyd, An Introduction to Indian Christian Theology, 170; Thangaraj, The Crucified Guru, 76.

73 Singh, Wisdom of the Sadhu, 63-69. Singh (1889-1929) was born in a well-todo family of Jat Sikhs. His mother deeply influenced his early religious life and introduced him to Sanskrit and Hinduism. His mother's death in his teens left him spiritually troubled and in urgent need to connect with God. This struggle lasted for two years, when at the age of sixteen, on a cold December night in 1904, Singh saw Yesu (Jesus) in a vision. He was baptized on his sixteenth birthday and soon thereafter became an itinerant preacher of the gospel in the mode of one who renounces the world. He travelled extensively throughout North India, visited Tibet regularly, and preached far and wide in Ceylon, Japan, China, France, 
Switzerland, England, and the United States. His works - mostly pamphlets and letters - include At the Master's Feet, Reality and Religion, Visions of the Spiritual World, and With and Without Christ. (Riddle, The Vision and the Call)

74 Boyd, An Introduction to Indian Christian Theology, 98; Heiler, The Gospel of Sâdhu Sundar Singh, 95-98.

75 Bulcke, Aimgrezī-Hindī Koś, 413.

76 Tsoukalas compares chapter 4 of the Bhagavad Gìtā (with Krishna's avătār) and commentaries on it by Śankara and Rāmānuja with notions of incarnation in Orthodox Christianity to reach his conclusion. (Tsoukalas, Krṣna and Christ, 117-130)

77 Tsoukalas, Krsna and Christ, 225-228.

78 Thangaraj, The Crucified Guru, 27.

79 Yale Digital Library Collection, digcoll 184118, page 318.

80 Sen, quoted in Boyd, Introduction to Indian Christian Theology, 81.

81 Boyd, Introduction to Indian Christian Theology, 81.

82 Greek text from Aland, Novum Testamentum Graece, 247.

83 Ärädhănā ke Gìt, Hymn 88.

84 McGregor, The Oxford Hindi-English Dictionary, 945.

85 Bahri, Rājapāl Hindì Śabdakoś, 407.

86 Dayal, Masīhī Dharmvigyān kà Paricay, 148.

87 Dayal, Masīhī Dharmvigyān kā Paricay, 148.

88 Dayal, Masīhi Dharmvigyān kà Paricay, 149.

89 Dayal, Masīhī Dharmvigyān kā Paricay, 149. English word in original.

90 Tsoukalas points to Telugu hymns that use avătär. Tsoukalas, Krsna and Christ, 225.

91 Howell, Parivartan, 194-195. At the time of publication of Parivartan, Howell was President of the Evangelical Fellowship of India (EFI). Founded in 1951 as a national alliance of evangelical Christians, EFI trains missionaries to witness the good news, seeks to transform India, and advocates for the poor and marginalized. Its legal arm (the Christian Legal Association) advocates on behalf of the rights and freedom of Christian converts and institutions.

92 Tsoukalas, Krșna and Christ, 165.

93 Howell, Parivartan, 170-171.

94 Howell, Parivartan, 171: Jo śabd hameri āge badhne meri sahāyak hai āie ham apne miśan ke śabdom ko pavitr śāstr kì vicārădhārā se lene kā prayatn karem.

95 Evangelical Lutheran Worship, number 283.

96 Ārādhănā ke Gìt, number 86.

97 Sham Rao, Five Contemporary Gurus, 46; cited in Thangaraj, The Crucified Guru, 87.

98 Amaladoss, The Asian Jesus, $147 \mathrm{ff}$.

99 Clarke, Dalits and Christianity.

100 Appasamy, The Theology of Hindu Bhakti; also see Boyd, An Introduction to Indian Christian Theology, 121.

101 McGregor, The Oxford Hindi-English Dictionary, 780.

102 Abbott-Smith, A Manual Greek Lexicon, 300.

103 A title of Viṣnu or Śiva. McGregor, The Oxford Hindi-English Dictionary, 604.

104 Arya, Kavitā mem Śubh Samdeś, xiv-xv: "Maine is prastuti ko is tarīke se sārvajanik aur vyāpak banāne kā pyrays kiyā hai, tāki kisī bhì dharm/samudāy ke pāthak ise padh sakate haim. Maine ise apnī samskrti ke nikaṭ bhī rakhane kā prayās kiyā aur "prabhu" śabd "yīs'u” ke lie aur "parameśvar" śabd "khudā" ke lie istemāl kiyà hai."

105 Hymns from Ārādhănā ke Gìt.

1 Babb and Wadley, Media and the Transformation of Religion, 1-5, 191, 212.

2 Babb and Wadley, Media and the Transformation of Religion, 198. 
3 Asad, Genealogies of Religion, 77-134.

4 Bonhoeffer, The Cost of Discipleship, 59.

5 Bonhoeffer, The Cost of Discipleship, 96.

6 Metaxas, Bonhoeffer, 140-143, 154, 172, 226, 262-263.

7 Bonhoeffer, The Cost of Discipleship, 117.

8 Bonhoeffer, The Cost of Discipleship, 119.

9 Bonhoeffer, The Cost of Discipleship, 248.

10 Bonhoeffer, The Cost of Discipleship, 155.

11 Bonhoeffer, The Cost of Discipleship, 158.

12 Barclay, Through the Year, 7.

13 Barclay, Viliyam Bārkle ke Sāth, I: "Dr. Viliyam Bārkle un thode se bāibil panditom mem se haim jinhonne bahut sahaj-saral śabdom mem bäibil kī mahān saccāiyom ko viśs ke sāmāny pāṭhkoin tak pahuincāyā hai. Bhāratīy pāsțaroin meim Viliyam Bārkle bahut lokpriy haim."

14 Anand's Preface in Sinha, Masīhī Ācaran: "[A]mingrezī pustak 'di kriściyans god' kà hindī anuvād ... Dr. Sì. Dablu. Devid ke karvākar ... [y]ah pustak itnī lokapiry huī ki dekhte-dekhte ek hì varș meì ise do bār chāpnā paḍ̄a. Āge calkar har varș iskā nayā samskaran prakāsit hotā rahā."

15 Anand's Preface in Sinha, Masīhī Ācaran.

16 David's Foreword in Sinha, Masīhi Ā Aaran, ii (kh): "Hindī masīhi sāhity kā durbhāgy hai ki uske pāthak bahut kam hai. Is sāhity ko na to kalīsiyā kī or se na bhāratīy samāj kī or se kō̄ praśansā yā viśeș protsāhan prāpt hai. Hindī bhāsiyom se àgrah hai ki ve jāgem aur acchī pustakoì ko paḍnne se apnī badnāmī ko dūr karem aur prabuddh hom."

17 Anand's Preface in Sinha, Masīhī Ācaran: "Hindī kśetrom ke thiyolājikal kalejoì ke prinsipal, carc ke biśap, pāstar, prakāśan samsthāem, hamārī pustakom ke vitrak, bords, miśnarì samsthāem hamārì bharsak madad kartī haim. Hamein viśvās aur āśa hai ki unkā prem hamāre prati bhaviṣy mem bhī banā rahegāa."

18 The Hindu Speaks, 530.

19 The Hindu Speaks, 482-483.

20 The Hindu Speaks, 83.

21 The Hindu Speaks, 42.

22 The Hindu Speaks, 13.

23 The Hindu Speaks, 24-25.

24 The Hindu Speaks, 249.

25 The Hindu Speaks, 212-213.

26 The Hindu Speaks, 40.

27 Lall, Susamācār-Pracār Darśan, 62: "Sākșì denā pratyek viśvāsī ke lie anivāry hai, jis viśvāsī ne prabhu yīśu ko apnā nij̄̄ muktidātā grahan kar liyā hai. Cāhe vah bade vyākhyān na de sakegā, cāhe badī sabhā merim kucch bolne se hickicāegā parantu nijī rūp se ek-ek jan ke āge apnì sākșī dene se na daregā. Kabhī-kabhī ismeri adhik safaltā bhī miltī hai. Vyaktigat pracār kì viśesatā yahì hai."

28 Lall, Susamācār-Pracār Darśan, 41: "Susamācār pracār memi is bāt par viśeș dhyān rahe ki kisī ke dharm aur viśvās kà koì khandan na hove. Khandan karnā àsān hai aur ho saktā hai ki baḍ̄ āsānī se ham bahas meì dīsre ko harā dem. Parantu isase kō̄ lābh na hogā. Mujhe ek bhāì ne kahā, 'ek khristī pracà̃rak ne ek sanātan̄̄ ko bahas mem burī tarah harāyā aur us samay se maim kbristīy dharm kā virodhī ho gayā.' Hamārā kām kisī kā khandan karnā nahīim hai. Hamārā kām yah hai ki apnī sākșì se prabhu se kisī vyakti ko milāeri ki usī daśā meì prabhu yīśu uskī sahāytā kar sake."

29 Lall, Susamācār-Pracār Darśan, 59-60: "Jab ek masīhī dūsre vyakti ko akele meì baițhar bātcīt karke susamācār kā saty samjhātā hai, aur apne jīvan kā anubhav bharose ke sāth dūsre ke sāmne rakhtā hai tab susamācār śrotā mitr 
kī samajh meì àtā hai aur use viśvās ho jātā hai. Yadi kō̄ praśn utpann bote haim to ve mitratā se hal kiye jāte haim. Bāībal ke pad kholkhol kar padhnā aur samjhānā, śrotā ke hriday par lāgū karnā hotā hai. Yahī vyaktigat pracār hai. Vyaktigat pracār ek-ek jan se milnà hai. Prabhu ne lūkā 15:1-7 mem khō̄ huī bhed kā driștānt dekar samjhāyā ki rakhwālā ek bhed kì khoj mein kitnā kașt uṭ̂àtā hai, aur usko dhūnḍh kar lātā hai. Isī prakār vyaktigat pracār-kāry karne vālā ek ke pīche pariśram karne aur kașt uțhāne mein āge baḍtā hai, aur use parameśvar se milātà hai.

Vyaktigat pracār kā lābh is bāt se bhī samajhie. Bājār v bhīd ke pracār meì kā̄ log susamācār pracār sunkar prabhāvit to hote hai parantu apnī buddhi, yogyatā, dharmaparāyantā dikhāne ke lie pracārak se kā̄ prakār ke vyarth praśn karte hai, pracārak ko mūrkh aur jhüthe dharm kà pracārak dikhāte hai. Kaī log to pustakeim kharīdkar fädeinge, fekeinge. Parntu maine dekhā hai ki unhìim se alag meì milo, bāt karo, to ek dūsrī havā ho jātì hai."

30 Anand and Vashisht, Merā Parosī, 9-10: "Is addhyayan kā uddeśy yah bhī nahī hai ki any dharmaviśvāsom kì jānkārī prastut kare. Iske viprìt iskā uddeśy yah hai ki hum apne padosiyom ke sambandh mem apne is bodh ko āge baḍāe ki ve àj tak jūvit dharmoì ke mānne vāle log hai. Unke dharm siddhānt evaim ācār-vyavhār jagat evam mānav samāj sambandhī masīhi logom ke dharmavaigyānik cintan ke abhinn ang hone cāhiyem. Dūsre śabdom meri kahe to yah, ki yah addhayan masīhī logom ko ek āvāhan hai ki ve apne padosiyom ke dharm-viśvāsom ko masīhì dharmavaigyānik bodh yā cetnā kā ang banàe. Ab tak masìhì cintan mein iske prati gambhīr driști nahīin apnāì gai hai. Par jab hamāre padosiyom ke dharm-viśvās hameim is bä̀t kī jānkārī dete hai ki hum kis rūp mem apne dharmasiddhāntom ko mānte aur samajhte hai, to hamāre liye yah anivāry ho jātā hai ki hum apne hì dharmaviśsuās ke naye àyāmoin ko khojne kī cunautī prāpt karein. Aisā karne se hum ek naye rūp meim apne padosiyom ke sambandh meim nayī jānkārì bhì prāpt kay sakenge aur ek adhik ghanișt samāj meim hum unke sāth miljul kar rah sakenge. Hamāre deś mein iskī sabse badī āvaśyakatā hai."

31 Anand and Vashisht, Merā Parosī, 55: "Vibhinn dharm paramparāom meì bhì unke anuyāȳ mānte hai ki unhe upne dharm viśvās ke liye sākșī dene kāa àdeś hai. Islām mem dharm pracār ek kartavy mānā gayā hai, kyomki islām kāa sandeś sārvbhaumik mānā jātā hai. Bauddh dharm ke pāth meì bhī isī bāt par bal diyā gayā hai. Bauddh mārg ko aisā mānā gayā hai ki vah sab logom ko mokș uplabdh karāegā. Par bauddh miśnom ko yah āvhān hai ki ve gahan prem aur mānav kì cintā aur dūsromi ke dharm viśvāsomi ke prati ādar rakheim. [Hindu] āvhān karte hai ki bhārat ke riși-muniyom kà sandeś sansār ko turant pahuincāem, kyoìki iske binā 'sansār kìà vināśs ho jaegā.' . . . Masīhī hone ke nāte humne bahudhā yah socā hai ki hum sandeś ke dene vāle hai aur dūsre log grahan karne vāle. Humne gavāhī ko ekmukhī prakriyā hì mānā hai. To any dharm mānne vāle logoin ke uprokt kathanoi் ke prati hamārī kyā pratikriyā hai, jab ki un kathanoi் meim sansār ko gavāhì dene ke sambandh meim samān tīur āgrah-bhāvanā, samarpan aur dāyitv ki abhivyakti hai?"

32 Lall, Susamācār-Pracār Darśan, 57: "Kaī deś picchle pacās varșoì mei் sāmrāiyvād se àjād hue hai. Ab ve svatantratā pā gae hai. Svatantratā pānā acchī bāt hai. Parantu is svatantratā ke sāth rāstrî̀y bhāvanāe tìur rūp meì kām karne lagì haim jinke kāran apne-apne deś kì sanskriti ityādi ko badhāne kā prayatn kiyā jā rahā hai. Masì̄ì viśvās ko sanskriti-ghātak batāyā jātā hai. Islie jo videś se pracārak àte the un par pratibandh lagā kar kah diyā gayā hai ki unke āne kī āvaśyakatā nahīì hai. Deś kī apnī mand lì sankbyā $v$ dhan mein itnī śaktiśāli nahìm hai ki apne kāry ko sambhāl sake, badhānā to asambhav hai. Kaì prakār ke sarkārī dabāv se nirbal viśvāsī manḍ̂̀ ko chod kar fir se purāne dharmom meìn cale jāte haim." 
33 Anand, Samprêsan, 32-34: "Mukti kā śubh sandeś hamei் likhit rūp meri hī prāpt hai: pavitr bāibil. Hamāre lie yah parameśvar kà vacan hai. Yah hamārì 'altìmeț athorițī' hai. Is alțīmet athorițī ko dūsrom par dikhāne ke pürv hamein pable apne jìvan mem apnānā hogā. Vyākhyā logom ko ākarșit nahīim kartī, par ācaran... . . 21-vìm śatābdì kà uttar bhārat kā hind̄̄ kșetr, hamāre sāmne ek gambhīr samasyā hai. Jab maim mukti kā śubh sandeśs sunāne kī bāt kartā hūim tab mere śrotā, darśak, pāthak, gair masīhī, viśeșakar mere Parosī hindī hote hai. . . .

Uttar bhārat kā masīhi samà̄ bhāṣā kì driști se triśanku hai: kadācit hindī filmoì kā koì ìsāi pātr jo bhāṣā boltā hai, usse hum is tathy ko samajh sakte haim. Hamāre videśì bhāiyom ne hameim sikhāyā ki hindī hinduoin kī bhāsā hai,

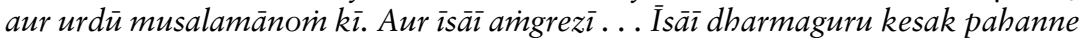
vālā keval roman kaitholik fādar hī ho saktā hai.

Hind̄̄ bāibil jo āpke hāth mem hai uskā anuvād san 1905 mein ilāhābād ke presbìtiri miśnarì dr. es. ec. kailāg ne kiyā thā. Sau vars pūrv hind̄̄ keval ek bolī thī jo uttar pradeś ke kucch jilom aur madhy pradés ke mahākośal kșetr meim prayukt hotī thī. Dr. kailāg ne sau varś pūrv kī sthiti ke anurūp kāry kiyā thā. Āj stithi bilkul bhinn hai. Hindī rāssț bhāṣā hai - sampark bhāṣā hai aur

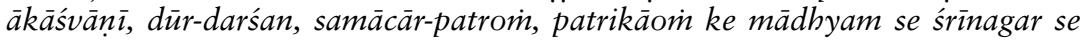
kanyākumārī, kucch-saurātr se arunācal tak prayukt ho rahī hai. Uskī śabdāvalī aur rūp bilkul badal gae hai. Pramukh śabdom ke arth badal gae aur nae-nae bhāvom ko abhivyakt karne ke lie nae-nae śabd hindī bhāṣā meì à gae haim.

'Mukti kā śubh samācār' ghoșit karte samay yadi sampreșak us bhāṣā kāa prayog nahī kartā jo sandeś grahan karne vālā samajhtā hai to śubh sandeś aśubh sandeś ho jātā hai, arth kà anarth ho jātā hai."

34 Schüssler Fiorenza, Jesus and the Politics of Interpretation.

35 Pintchman, Women's Lives, 4.

36 James, Mahilā Dharmavijũān, 227: "[S]amāj meì rahnevālī bahanom se aur any sadasyoim se prem ke sāth vyavahār kar sake ... dukhbharī kahāniyāmin sun saktī hai aur dukhit hridayoì ko śānti de saktī hai ... samarpit masīhì mahilā... saccī, mitratāpūrn aur śālīn . . . logoì kì bāt sunne, unko ucit smay par salāh dene, aur gopanìy bātom ko man meì rakhne kì kșamatā honì cāhiye.

37 James, Mahilā Dharmavijūān, 228: Pati ke samast dāyitv meì uskā saprem sāth de.

38 James, Mahilā Dharmavijūān, 231-232: Kalīsiyā ke jīvan aur pracār kāry meim striyom kā bhārī hāth rahā hai. Hamāre prabhu ne ārambh se hī strī ko anugrah aur sevā meì puruṣ ke barābar mānā hai (dekhie yūhannā 4:7 kramik pad; markus 5:23 se āge; lù kā 10"38-42). Yah mānā ki striyom ko celom ke samān āścaryakarm karne kī sāmarth sahit prabh ne nabìm bhejā, parantu celom ke samudāy mei் sevā, sahāyatā aur ātithy satkār mei் unkā viśeș bhāg rahā (lūkā 8:2; markus 15:40 se āge). Unmeim se kucch striyāim punurutthit khrist kì sarvpratham gavāh thīin (markus 16:1). Yīśu ke driștāntom meì striyoin ko mahatvapūrn sthān hai. Preritom ke kām aur patriyom meim anek striyom kā ullekh hai jo susamācār pracār mem sahāyak thīm (preritom ke kām 1:14; 12:12; 16:13 se àge; romiyom 16:1, 3; 1 kurinthiyom 1:11; kulussiyom 4:15; 2 tìmuthiyus 1:5; filemon 4:2-3). Kalīsiyā mem striyāim anek

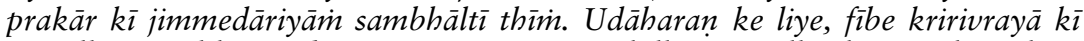

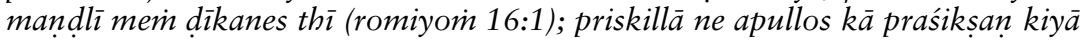
(pre. 18:24-26); tìtus 2:3-5 mem் presbitar mabilāom kā ullekh hai; vidhväem parbit prārthanā kì sevā mem lagī rahtī thì (1 tìm. 5:5). Aisā pratīt hotā hai ki prārambhik kalīsiyà mem nabiyā bhì thì (pre. 21:9). Sant paulus striyom ko 'mere sahakarmì' kabtā hai (ro. 16:3). Yah mānā jā saktā hai ki hamāre prabhu yīśu kbrist ke dvārāā aur striyom ke prati prārambhik kalīsiyā kì abhivritti ke kāran mānav samāj meì striyoì kā star üincā huā hai. 
Is paramparā ke anurūp āj mahilāem kalīsiy $\bar{a}$ mem anek prakār se sevā kar rahī haim, yahāim tak ki kucch kalīsiyāom mem unko pādrī yā presbitar bhī banāyā gayā hai. Striyoì ko kalīsiyā mein matdān kā adhikār haim; ve mandalì meim anek rūpoí mem sevā kartī hai, bāibil vìmen pracār kāry kartī haìi, mahilāyem skūlom mem śikșā detī haim, aspatālom meỉ kāry kartī haim, miśnarī haim, sahāyak pādrī haim, ādi.

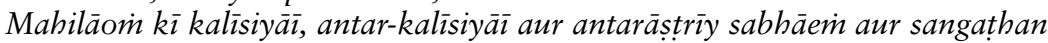
haim. Yah bade śrey kì bāt hai ki ve hosțel, skül, aspatāl aur samsthāem jo mahilāom ke hāth meì haim kaī bātom mein śreșth haim."

39 Schüssler Fiorenza, Discipleship of Equals, 159-161.

40 Schüssler Fiorenza, Discipleship of Equals, 157.

41 James, Mahilā Dharmavijūàn, 234-235: "Sab se acche pad aur vișay vahìm hote haim jo ghutnom par prärthanā ke samay updeśak ko milte haim ... Yah kabhī na kariye ki āp updeś pable taiyār kar lem aur tab pad dhündhate firem . . A Āp ke jordār vicār binduom ko äkhir mem aur kamjor vicār binduom ko pable rakhie... Updeś ko jīvan par lāgū karnā cāhiye aur usmeín vyaktigat apìl bhī honā cāhiye... Apne updeś ko soc lene ke bād updeś dene kā abhyās kījie. Āp ke uccāran, abhivyakti, bāibal ke sandarbh thīk se niścit hoim. Āp apnā updeś likh lemi yā uske nots banā lem. Yah pakkā bharosā rakhie ki parameśvar āpke kām par āsis degā."

42 Paul, Striyoì kā Parameśvar ke Sāth Calnā, 217: “Ādhunik striyāim anek prakār se yogy hotì haim. Vah kaī tarah ke kāryom ke liye ucit rahtī hai . . . Vah kalīsiyā kì sammatiyom par salāhakārī ke vibhāv meì, àtmā jītne kī upcārikà ke rūp mein, prabhubhoj taiyār karne ke lie, baccoin ko susamācār ke bāre mem batāne ke liye, prārthanā mandaliyom ko calāne ke lie, yuvā kī aguvāì karne ke dvārāa,

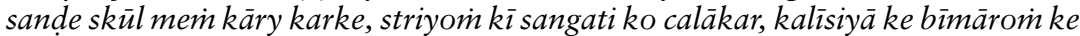
pā jākar, vidhavāom evam anāthoi் kī dekhbhāl karke, tankan kāry (țāīping) karke, dān ekatrit karke, āgantuk satkārī hokar, aur in sabke ūpar muskurā kar, kalīsiyā kì sevakāi kar saktī hai."

43 Paul, Striyomi kā Parameśvar ke Sāth Calnā, 116: "Masīh kì driști mein striyāim achūt nahìin thī."

44 Cf. Schüssler Fiorenza, Discipleship of Equals, 152, note 2.

45 Paul, Striyoì kā Parameśvar ke Säth Calnā, 15.

46 Paul, Striyom kā Parameśvar ke Sāth Calnā, 32: "Uskā yah bhī adhikār hai ki manusy kī apekșā parameśvar kī āgyā pālan kare."

47 Paul, Striyom kà Parameśvar ke Sāth Calnā, 31: "Svarg mem kō̄ strīling athavā purling nahìm hai. Ling bhed keval is dhartī par hī hai, svarg meì koī ling bhed nabìm hai."

48 Paul, Striyom kā Parameśvar ke Sāth Calnā, 31: “Ek strī kā apne pati, bacce evam ghar ke ūpar adhikār hotā hai."

49 Paul, Striyom kà Parameśvar ke Sāth Calnā, 132: "Striyoṁ ko puruṣom ke üpar adhikār nahìm jamānā cāhiye."

50 David in James, Mahilā Dharmavijñān, xii: "Kalīsiyā aur bhārat bhūmi ke kalyān ke nimitt pustak ke lekhakoim aur sankalan kartī ke sāth hum bhī apne ārādhy prabhu yiśu khrist ke carnom mein ise samarpit karte haim."

51 James, Mahilā Dharmavijñān, 103: "Khristīy jūvan dubrā jīvan hai. Ismem àdhyātmik aur naitikatā donoì kā gahrā sambandh hai."

52 James, Mahilā Dharmavijūān, 102: "Pratyek khristìy jan ke liye yah āvaśyak hai ki vah apne ācaran banānevāle siddhāntom ko jāne aur unke sambandh mei் use niścay ho."

53 James, Mahilā Dharmavijūān, 108: "Parivār ke prati kartavy; samāj aur samudāy ke any logoin ke prati kartavy; deś ke prati kartavy." 
54 James, Mahilā Dharmavijūān, 107-108: “Adhikār jinke pās haim unkā yah naitik dāyitv hai ki ve sab ke kalyān ke liye uskā upayog karem. . . jivan ke prati $\bar{a}$ dar; ātmā-rakșā; svāsthy rakșā; $\bar{a} t m$ hatyā na karnā aur na dūsrom kì hatyā

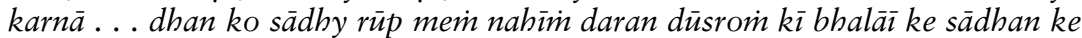
rūp memin arjit karnà cāhiye. Dūsromi kì sampatti kā ādar karnā cāhiye .. buddhi, gyān, kauśal ādi kā vikās [karnā] . . saty bolnāa, apnī icchāom, abhivrttiyom aur

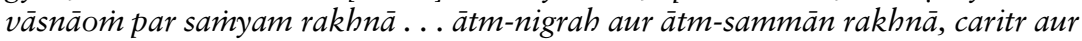
sāmājik vyavasthā kā sammān karnā; gati tathā ìmāndārī se kațor śram karnā."

55 James, Mahilā Dharmavijũān, 107: "Samāj adhikār kā srot hai. Kucch śartom ke sāth samāj vyaktiyom ko adhikār pradān kartā hai. Śart yah hai ki jinko adhikār die jāte hairm ve unkā ucit upayog karemi aur dūsrom ko asuvidhā na pahuincāne hetu unko kām meì lemin. Khristīy nìtiśāstr meì manuṣy ko jo abhikār prāpt haim unmei் vyakti ke sammān evam mūly jhalakte haim. Manuṣy ke adhikār ye haim: (1) jīvan aur śram kā adbikār, (2) śikșan kā adbikār. (3) Svatantratā kāa adbikār. (4) Sampatti kāadhikār. (5) Ikrārnāmā yā anubandh karne kā adhikār."

56 Dayal, Vyaktigat Manan-Cintan, 10: "Var de ki maim ne jo pable pratigyāyeim kī haim, unhe na tod̄u aur jo galtiyāim kī haim, unko binā sudhāre na chod̄u. Var de ki yadi maim kisì humrāhō ko sankat mein dekhūim to katrā kar na calā jāūim. Var de ki maim kartavy ko pūrā kiy bagair na chod dūm aur na kisì burī ādat ko kāyam rahne dūim. Jahāim merā kō̄ kāry sansār ko manuṣyomi ke rahne ke lie behtar banā saktā hai, jahāim merā vacan kisī nirāś man ko protsāhan de saktā hai yā kamjor icchā-śaktivāle ko dridh kar saktā hai, jahāim merī prārthanā muktidātā prabhu yeśu ke rājy ko vistrit kar saktī hai, vahāì mujhe karne, bolne aur prārthanā karne kī sāmārthy de."

57 Dayal, Vyaktigat Manan-Cintan, 34: "Pyāre pitā, āj din bhar mere jīvan kì tū rakșā karnā. Mere samast vicārom் aur bhāvanāom ko niyantran mei் rakhnā, merī yogyatāom kà sancālan karnā. Merī buddhi ko sikhānā. Merī icchā-śakti ko sambhālnā. Mere hāthoin ko lekar apnī àgyāom kā pālan karne ke lie mujhe furtìlā banānā. Merī ākhom ko lenā aur unhem apnī anant sundartā par lagā kar rakhnā. Mere muìh ko lenā aur use apne prem kì gavāhī kā prabal vaktā banānā. Is din ko āgyāpālan kā din, ātmik ānand aur śānti kā din banānā. Is din ke kāryo ko muktidātā prabhu yeśu ke rājy kā hissā banānā."

58 Jonathan, Biśap, 22: "Kalīisiyā se bāhar ke logom memi, vistrt samudāy meì hamāre

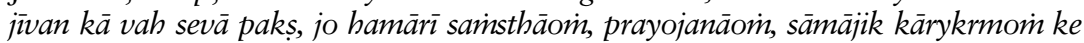
mādhyam seì vyakt hotā hai, hamāri pahcān kā cinh hai. Hamārī pahcān hamāre dāyitvoì ko . . vahan karne se honì cābiye."

59 Patlia, Pāstarī Viddhyā, 49-50: "Sambhav hai ki vah bahusankbyak samudāy ke hathkandọi ke kāran apne adhikārom kā upayog [pūre] rūp se na kar sake. . .[par] àvaśyakatā padne par śānti aur prem kā aisā sangharṣ kar saktā hai ki mahān se mahān śaktiyām bhī jhuk jāerin, uttam sākșī utpann ho aur parameśvar kā rājy pragatiśîl ho sake."

60 Patlia, Pāstarī Viddhyā, 50.

61 Patlia, Pāstarī Viddhyā, 49: "Jahāim gantantrātmak svatantratā kā adhikār hai, vahāim ek samāj ko, cāhe alpsankhyak hì kyom na ho, apne nāgrik adhikārom ko prāpt karne ke lie sangharș karne kì pürì svatantratā hai."

62 David's preface in Sinha, Masīhi Ācaran, i (k): "Masīhì ācaran kī prāpti evam prasār viśv kalyān evam pragati ke liye anivāry hai."

63 Sinha, Masīhi Ā caran, 1: "Ve log bhī, jo masīhi nahìm haim, is bāt se paricit haim ki masīhiyom ko masīh ke samān honā hai. Sansār mei் bahut log, jo masīhì nahīim haim, prabhu yīśu ke caritr ko bhalībhainti jānte haim. Unhe is bāt kā gyān hai ki prabhu yīsu nyāyapriy, namr aur śuddh ācaran karne vālā tathā satybhāṣ̂̄ jan thā." 
64 Sinha, Masīhì Ācaran, 2: "Hum to prabhu yīśu ko dekh nahīim sakte, parantu hum āpko dekh sakte haim."

65 David's preface in Sinha, Masīhi Ācaran, i ( $k$ ): "Is pustak meim masīhi ācaran kā $\bar{a}$ darś, masīhi sadgun, tathā is ādarś evam in sadgunom ko apnāne ke sāmarth srot kā atyant sundar aur rocak vivecan kiya gaya hai."

66 Howell, Parivartan, 170-171.

67 Howell, Parivartan, 171: "Hameì lagātār apne vyavăhār aur bhāṣā ko jāincte rahnā cāhie."

68 Anand, Samprêșan, 6-7.

69 Rajagopal, Politics after Television, 84, 326.

70 Rajagopal, Politics after Television, 76-77.

71 Mankekar, Screening Culture, 5.

72 See also Mankekar, Screening Culture, 255.

73 Rajagopal, Politics after Television, $76 \mathrm{ff}$.

74 Mankekar, "Epic Contests," 143.

75 Rajagopal, Politics after Television, 73.

76 King, Nehru and the Language Politics of India, 78.

77 Gill, "Why Ramayan on Doordarshan."

78 Scharf, Rāmopākhyāna.

79 Mankekar, "Epic Contests," 143.

80 Rajagopal, Politics after Television, 327.

81 Engineer, Babri-Masjid, $1 \mathrm{ff}$.

82 Khan, The Great Partition, 62.

83 Khan, The Great Partition, 129.

84 Khan, The Great Partition, 135.

85 Khan, The Great Partition, 156.

86 Khan, The Great Partition, 176.

87 Quoted in Engineer, Babri-Masjid, 8.

88 Engineer, Babri-Masjid, 10-13.

89 Varshney, "Contested Meanings," 232.

90 Varshney, "Contested Meanings," 253.

91 Varshney, "Contested Meanings," 247.

92 Varshney, "Contested Meanings," 249.

93 Rajagopal, Politics after Television, 81ff.

94 Rajagopal, Politics after Television, 83.

95 Mankekar, "Epic Contests," 145.

96 Rajagopal, Politics after Television, 84, 117-118.

97 Also see, Rajagopal, "Ram Janmbhoomi,” 1661.

98 Varshney, "Contested Meanings," 232-233.

99 Rajagopal, Politics after Television, 84, 161-162.

100 Mankekar, "Epic Contests," 140.

101 Varshney, "Contested Meanings," 230.

102 Andersen and Damle, The Brotherhood in Saffron, 33-34.

103 Varshney, "Contested Meanings," 230-231.

104 Pollock, "Ramayan," 264; referenced in Mankekar, "Epic Contests," 143.

105 Pollock, "Ramayan," 289.

106 Thapar, "The Ramayan Syndrome."

107 Mankekar, "National texts and gendered lives," 545-546.

108 Anand spelled the Hindi ("Bāibil ki Kahāniyām") differently than Doordarshan did ("Bāibal kī Kahāniyāim") - with no difference in meaning.

109 The original Hindi pronoun (unbone) is gender non-specific.

110 Anand, Samprêșan, 35-36: “'Bāibil kì kahāniyām’ dūrdarśan sìriyal ek aur mahatvapūrn udäharan hai. Jis utsāh aur utsuktā se lagh-bhag 10 karoḍ darśakomin ne 
iskā pablā-dūsrā epīsod dekhā thā aur tīsre-cauthe epīsod meì darśakoin ne apne-

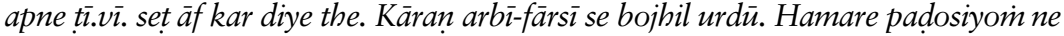
hum se pūchā ki kyā bāibil kì bhāṣā bhì 'kurān' kì bhāṣā jaisī hai? Kitnā galat Samprêsạn huā thā. Śubh sandeś aśubh sandeś ban gayā thā. . . . 'Bāibil kī kahāniyām’ sìriyal kī pāndulipi ke sambandh meì dūrdarśan ke uccādhikārī se

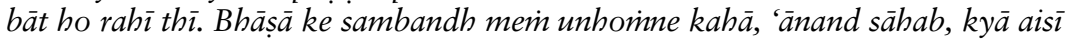
bhāsā rāstrīy kārykram ke lie upyukt hai?'

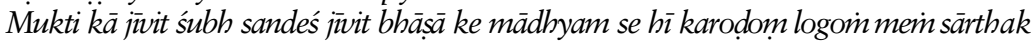
dhang se sampreșit honā cāhie. Aur iske lie āvaśyak hai bhārat kī bhāṣāom kā pūrnagyān. Yadi maim hindī bhāșā kā nivāsì hüm, merā kāry kșetr hindī bhāṣā kṣetr hai to mujhe hindī bhāsāa kāa gyān honā cāhiy. Uskā vidhivat adhyayan karnā cāhie."

111 Bhajan and Khan, Isläm, 234-246.

112 Dayal, Uttar Bhārat aur Pākistān, 201.

113 Anand and Warne, Samprêșan, 156-157.

114 Union of Catholic Asian News, "Bible series taken off national television after alleged Muslim threats," March 31, 1993.

115 Mankekar, "Epic Contests," 149, note 25.

116 Anand's preface in Khan, Samvvād, I: “Parameśvar ne hum-masīhiyom ko ek

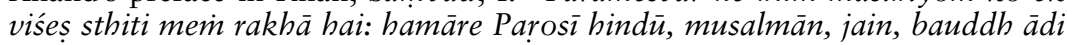
haim. Inkā dharm, viśsās, bhāsāa tathā sanskriti bhì bhinn hai. Vāstav meì hum bahudharm tathā bahusankriti ke pariveś mein rah rahe haim. Dūsrī or alpsankhyak dharmāvlambī samāj hone ke kāran hum kis prakār apne Parosī ko prabhu yīsu kà antim ādeśs sunā sakte haim?"

117 Anand, Samprêșan, 35: "Ek aur mahatvpūrn bāt: āpapnībāt-cìt meì, prārthanā meim prabhu parameśvar ke lie ādar sūcak sarvnām 'āp' kā prayog karte haim. Yah hamārì bhāratīy sanskriti hai. Lekin jab hum ākāśavānī, dūrdarśan, lok sabhāom meim bāibil paḍte haim aur tu, terā jaise sarvnāmoin kā prayog karte haim, to lajjā se sir jhukānā padtā hai. 'Yeśu gayā', 'yeśu bolā!'.”

1 McGregor, The Oxford Hindi-English Dictionary, 606, lists the following as translations of paricay: acquaintance (with); knowledge, experience (of); information, data; to introduce (one to); to acquaint (with); to make known (to); or, to demonstrate.

2 Biographical details are from Khan's Khristīy Nìtiśāstr (1981: viii) and Bīsavìn Śatābdī ke Pramukh Dharmavijūānī (1990; v-vi).

3 Khan's doctoral dissertation was published in English as The Concept of Dharma in Valmiki Ramayana by Munshi Ram Manohar Lal press (Delhi) in 1965.

4 Both Khristīy Nìtiśāstr (viii) and Islām: Ek Paricay ("Islam: An Introduction"; vi) were first and original books in Hindi Christian literature on their subjects. Both books have been quite popular: due to continued demand, Khristīy Nìtiśāstr was republished in 2009. Isläm went through a new edition in 1987 and was republished in 2004.

5 Bhajan and Khan, Islām, viii.

6 Khan, Khristīy Nìtiśāstr, v: "Mere śodh prabandh 'vālmīki rāmāyan mein dharm kā svarūp’ ke prakāśan uparānt merī yah hārdik abhilāșā rahī ki maim hindī meim khristīy nìtiśāstr par bhī pustak likhūim aur us samay se hì maim is viṣay kāa viśeș adbyayan kartā rahā hüm."

7 Scharf, Rāmopākhyāna, 8-15.

8 Scharf, Rāmopākhyāna, 429-437.

9 Flood, Hinduism, 66.

10 Flood, Hinduism, 109. 
11 Khan, Khristīy Nìtiśāstr, vi: "H.T.L.C [kā] àgrah rahā ki sirāmpur kāimlej kī bì. tìec. evam bì. di. parīkșāom ke chātroì ke hitārth tathà unke pāthykrm ke ādhār par khristīy nìtiśāstr pustak likhī jāe."

12 Bhajan and Khan, Isläm, vi: "[Yah] pustak sīrāmpur sinet ke bī. țiec., evam bì. dì. ke chātroì kī àvaśyakatāom kì pūrti hetu bhī likhī gaì hai."

13 Bhajan and Khan, Islām, vi: "Hamārā viśsās hai ki samast hindi bhāṣ̄ pāṭakoì tathā saty ke anveșakoì ke liye hamārā vinamr prayās mūlyavān aur mūlstambh hogā."

14 David, in Bhajan and Khan, Islām, viii: "Yah saty ke anveșakom ko preranā pradān karegī, aur paraspar saṃvād evam deś kì ekatā ko baḍ̆hāne meì sahāyak bogì."

15 Khan, The Concept of Dharma, 40.

16 Khan, The Concept of Dharma, 135.

17 Khan, Khristīy Nìtiśāstr, v-vi: "[K]bristīy dharm evam nìtiśāstr, kbristīy dharmavijũān evam nìtiśāstr aur khristīy viśvās evam nìtiśāstr mein ek atūt sambandh hai....

[Masīhīyatā meì] pāpī manuṣy kā parameśvar se mel-milāp pramukh siddhānt hai aur yah khrist ke balidān ko svīkār karne meì sambhav hai. Manuşy kī saccī dhārmiktā uske apne prayās, apnī dhāritā, apne dharmakāry par nirbhar nahīì varan is anubhav par ādhārit hai ki parameśvar se uskā mel-milāp (Reconciliation) huā hai athvā nahīin. Manuṣy apnī śakti aur prayās dvārā dhārmik nabìm ban saktā. Yah to usmem aham paid̄a kartā hai. İ́svar ke samakṣ pāpī samarpan kar, iśsvar se śakti prāpt kar naitik-kāry kar saktā hai. Isī anubhav se manuṣy ke jīvan, uske kāry aur uske sambandhoim meim ek nayā mod ātā hai aur vah naitik jīvan vyatīt karne lagtā hai. Isīlie kbristīy dharm aur kbristīy nìtiśāstr ek dūsre se prthak nahìm varan anany hai aur yah bhi saty hai ki khristīy dharm meim bum naitik jīvan vyatìt kar iśvar se milāp nahìm karte varan iśvar se milāp kar naitik jīvan vyatìt karne kì śakti prāpt karte hai. Isī pürvdhāranā ko samaks rakhkar maim khristīy nītiśāstr par ek pustak likhne kà ek chotā-sā prayās kar rahā hūim."

18 Khan, The Concept of Dharma, v: "Vah vrtti yā ācaran jo lok yā samāj ki sthiti ke lie āvaśyak hai; vah ācār jiske dvārā samāj kī rakșā tathā sukh-śānti kì vrddhi ho aur parlok meì bhi uttam gati prāpt ho."

19 The feminine possessive is my addition; the original possessive $(u s k \bar{a})$ is gender non-specific.

20 Khan, Khristīy Nìtiśāstr, 18: "Dharm ìśvar ko sat cit ānand kahtā hai. Kucch vidvān satyam-śivam-sundaram kahte haim. Yadi yah paribhāṣā saty hai to nìtiśāstr aur dharm meim ațūt sambandh pramānit hotā hai, kyomki jis śubh (śivam, Good) kā naitik śāstr adbyayan kartā hai, vah dharm ke iśvar kà gun hai. Fir hum yah bhī jānte haìm ki hum naitik praśnom kà us vakt tak koī sahì uttar nabìm de sakte jab tak hum is bāt ko niścit na kar lem ki manuṣy kī prakrti kyā hai, brahmānd meì uskā kyā sthān hai, aur brahmānd kā kyà svarūp hai. Atạ hum is nișkarș par pahumcte hai ki tārkik evam vyāvahārik rūp se dharm aur nìtiśāstr meim ghanișth sambandh hai."

21 Khan, Khristīy Nìtiśāstr, 30: "Nìtiśāstr manuṣy ke vyavahār meì śubh aur aśubh ke adhyayan kā sāmāny vijūān hai. Iske adhyayan se hamem mānavīy mūlyom kā gyān hotā hai aur hum yah bhī jānte haim ki vyāpār meì, cikitsā meì, āpsī sambandhoì meì kaun sā vyavahār ucit hai aur kaunsā anucit hai; kyā śubh aur kyā aśubh hai."

22 Bhajan and Khan, Islām, v: "Āj kal masīhiyom mem bhī ek nayā āndolan cal rahā hai jis kā lakșy sansār ke vibhinn dharmoì ke mānne vālom ke madhy prem kā sambandh sthāpit karnā hai. Āvaśyakatā is bāt kī hai ki vibhinn dharmoin ke mānne vāle āpas meim prempūrvak baiț kar ek dūsre kì bāt sunem aur mil jul kar paramsaty kỉ khoj karem. Aisā saty jo hrday meì us śānti ko bhar 
de jis se ek nav-mānav kà uday ho aur jo prem aur āśā se paripūrn ho. Is naye àndolan kà nām samvād (Dialogue) hai. Is kā matlab yah nahìin ki hum ek dūsre par kicad ucchālem, varan yah hai ki hum premamay vātāvaran mein baith kar dhairy aur śānti se ek dūsre kì bāt sahānubhūti se sunem aur samjhem, ek dūsre se sīkhem aur jahāim tak ban pade jantā kì bhalāì ke liye ek dūsre kī sahāytā karem. Is āndolan ko safal banāne ke liye yah āvaśyak hai ki hum dūsre dhar-

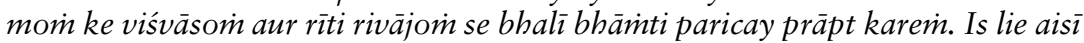
pustakem, jo vibhinn dharmoin ke viśvāsom, rasmorivājom, naitikatā àdi ko ucit dhang se prastut karem, avaśy hì samay kī ek badī āvaśyakatā ko pūrā kareingī."

23 Lossky, Dictionary of the Ecumenical Movement, 311-317.

24 Robinson, Christians Meeting Hindus, 4-5.

25 Robinson, Christians Meeting Hindus, 21.

26 Robinson, Christians Meeting Hindus, 32-34.

27 Robinson, Christians Meeting Hindus, 60-77.

28 Balagangadhara, Reconceptualizing India Studies.

29 Balagangadhara, Reconceptualizing India Studies, 159.

30 Balagangadhara, Reconceptualizing India Studies, 164.

31 Robinson, Christians Meeting Hindus, 77.

32 McGregor, The Oxford Hindi-English Dictionary, 913.

33 McGregor, The Oxford Hindi-English Dictionary, 967.

34 Bonhoeffer, Letters and Papers, 359-360.

35 Bonhoeffer, Letters and Papers, 359.

36 Bonhoeffer, Letters and Papers, 346.

37 Bonhoeffer, Letters and Papers, 326.

38 Bonhoeffer, Letters and Papers, 361.

39 Bonhoeffer, Ethics, 132 (emphasis added).

40 Bonhoeffer, Ethics, 130-132.

41 Metaxas, Bonhoeffer, 155.

42 Bonhoeffer, Ethics, $193 \mathrm{ff}$.

43 In Bonhoeffer's words: "Ethical thinking in terms of spheres, then, is invalidated by faith in the revelation of the ultimate reality in Jesus Christ, and this means there is no real possibility of being a Christian outside the reality of the world and that there is no real worldly existence outside the reality of Jesus Christ. There is no place to which the Christian can withdraw from the world, whether it be outwardly or in the sphere of the inner life." (Bonhoeffer, Ethics, 198)

44 Khan, Khristīy Nìtiśāstr, 161-162: “Bāimnahūfar apnī pustak 'ethiks' memi lūthar kì us àlocanā ko jo lüthar ne dvaitavād (Thinking in Terms of Two Spheres) ke viruddh kī thī, svīkār kartā huā manuṣy ke prākrtik evam aprākrtik staroì kī ghor ālocanā kartā hai. . . . Is dvaitavād ke anusār naitikatā ke bhī do star māne jāne lage ... niyam, un logom ke lie jo ki präkrtik star par rabte haim aur àdhyātmik pürnatà un logom ke lie jo dharmì haim, jinhomne masīhī jīvan vyatìt karne kà niśsay kar liyā hai. ...

Bāinnahūfar is dvaitavād ko avāstavik kabtā huā likhtā hai: "Ek masīhī, masīh ko svīkār karne ke paścāt kisī antardvand kā kșetr nabìm ban jātā parantu jis prakār masīh ek hai vah bhī antardvand se mukti pā ek avibhājit ikāì ban jātā hai aur vah do starom par nahìì rahtā, sadaiv ek star par rabtā hai.” . . . Bāmnahūfar likhtā hai ki is prākrtik jīvan ko hum yah na mān baithem ki yah masīh ko svīkār karne se pable kà jīvan hai parantu yah jīvan to vah hai jo masīh yīsu dvārā mānyatā prāpt hai.

Sārāinś meì hum kah sakte haìm ki bāmnahūfar ne upāntim par jor dekar is duniyāvī jūvan ko nayā arth pradān kiyā aur nā̄ mahattvatā dī. Isī prakār do starom athavā dvaitavād ko ḍah kar yah pramānit kiya ki yah jagat masīh ko is duniyā kā prabhu mānne merm avarodh utpann nahīm kartā varan sahāyatā detā 
hai. Ek masīhì ko yah jānnā cāhie ki ek masīhì manuşy hai aur vahì manuṣy, manuṣy hai jisne ki dehadhārī masīh ko svīkār kiyā hai."

45 McGregor, The Oxford Hindi-English Dictionary, 44.

46 Bonhoeffer, Ethics, 196.

47 McGregor, The Oxford Hindi-English Dictionary, 60; Bulcke, Amgrezī-Hindī Koś, 835.

48 Bonhoeffer, Ethics, 198.

49 Khan, Khristīy Nìtiśāstr, 162: "Masīh mānav jīvan ke lie ek udāharan hai. Usne kyā kiyā, kaise rahā, kyā uskā jīvan thā; vah manusyo me rahtā thāa, unke sāth khātā-pìtā thā, unkī bhāinti sotā-uthtā thā aur unme ek naì mānavatā ko jograt

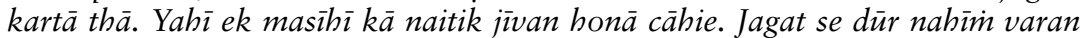
jagat ke madhy aur yahī carc kā kāry bhī honā cāhie."

50 Khan, Khristīy Nìtiśāstr, 162: "Carc kā is jagat mem ek sthān hai. Carc is jagat $k \bar{a}$ ek tukdā hai. Carc kà is jagat ke prati ek uttardāyitv hai, islie carc ek vah samāj hai jiskā uttardāyitv jagat ke prati hai. Use is sansār meì kūd jānā hai, jo ìsvar ko nahìm māntā. Vah usse dūr rahkar kōi kāry nahìm kar saktā."

51 Bonhoeffer, Ethics, 199-200.

52 Bonhoeffer, Ethics, 72.

53 Khan, Bīsavìn Śatābdī ke Pramukh Dharmavijūānī, 146: “Ādarśoì, kāryakrmoim, antarātmā, kartavy, uttardāyitv aur sadgun dvārā hum sattā kā na to sāmnā kar sakte haim aur na hì us par vijay pā sakte haim. Yah kāry hum ìsvar se prem ke dvārāa, aise prem ke dvārā, jo ek sāmāny pratyay nahīin parantu sampürn prem hai, kar sakte haim."

54 Khan, Bìsavìm Śatābdīke Pramukh Dharmavijñānī, 146: "Is prem ko bāinnahūfar masīh meì ìśvar se prem kī sagyā detā hai, aur use vah 'iśsvar se prem mein jīnā' kahtā hai."

55 Khan, Bīsavìm Śatābdī ke Pramukh Dharmavijñānī, 146: "[Yah prem] manusy ko sansār se bhāgne ki preranā nahìin detā parantu is bāt kī ksamatā pradān kartā hai ki vah sansā kī sab vipattiyom ko jhele, jaise yīsu-masìh kì deh ne pāp ke krodh ko sahan kiyā. Carc ke liye bhī yah jarūrī hai ki vah sansār ke liye apne āpko jokhim meì dàle. Ek masīhì, masīh meim hotā huā bhì sansār meri sthit hai."

56 Khan, Bīsavìm Śatābdī ke Pramukh Dharmavijūānī, 147: "Bāinnahūfar . . . hameì batātà hai ki hameim is sansār ko baḍ̄ sanjīdagī se lenā cāhiye. Ise pyār

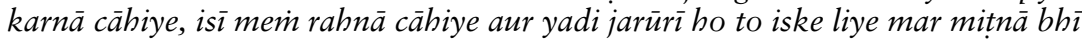
cāhiye. Hamārā susamācār kisī palāyanvādì dharm kī sthāpanā nahīin kartā."

57 Khan, Bīsavìm Śatābdī ke Pramukh Dharmavijñānī, 162: "[Dharmanirpekșavādī] dharmavijñān ne carc ko niścit rūp se ek nayā pāth padhāyā. Vah yah hai ki carc manusyomin kì sānsārik kathināiyom aur samasyāom mèm pūrā sakriy yogdān de. Jis prakār purānā niyan kà iśvar isrāel kaum ke ādhyātmik, sāmājik aur bhautik pahaluom ko barābar chūtā hai usī prakār āj aise ìsvar kī, jo is sansār mem samast mānav-jāti kì ādhyātmik aur bhautik sahāyatā kare, àvaśyakatā hai."

58 A 'crore' equals ten million.

59 A 'lakh' equals hundred thousand.

60 Bulcke, Aimgrezī-Hindī Koś, 744.

61 Bhajan and Khan, Islām, vii: "Islām sansār ke pramukh dharmoin meim se ek hai. Vartamān bhārat mem islām ke anuyāyiyom kī sankhyā bahusankhyak hindū dharmāvalambiyom ke bād hì hai. Inmein se adhikānś hindī bhāṣì kṣetr mei் rabte haim. 1971 kī jangananā ke anusār bhārat mem 45.3 karod hindī, 6.1 karod muslim, 1.4 karod khristī, 1 karod sikkh, 38 lākh bauddh aur 20 lākh jain dharmoì ke pālan karne vāle haim. Ye ank yahāim rāṣtr kī prthakatā ke liye nahìm, varan is tathy ke mahatv ko samajhane ke liye die gae haim ki hamāre deś mein dharm-viśvāsom evam dharmanìtiyom mem antar hai aur ki hum ek 
dūsre ke dharm kā adbyayan kareì aur yah jānte hue bhī ki sab dharm samān nahīin haim hum ek dūsre kì bhāvanāoin kā ādar karem.

Islām ek paricay pustak ke taiyār karne mein tīn uddeśy haim jin mem se do kā ullekh lekhakoin ne apne prākkathan mein bhī kiyā hai: pablā paraspar samvād (Dialogue) meì sahāyatā prāpt ho; dūsrā sīrāmpur sīnet ke bì. tịec. aur

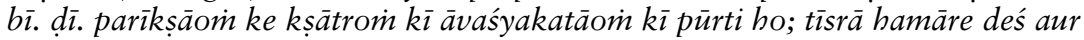
viśesakar hindī-bhāsī yah samjhem ki dharmoin me samāntā na bote hue bhī dharm ke nām par deś meri aur viśeș kar hindī bhāṣi kṣetr merin rāṣtrīy aur naitik jīvan samrddh ho. Is ke sāth hì kisì bhì dharm kà samyak gyān apne hì mein ek apūrv lābh hotā hai."

62 Khan, Khristīy Nìtiśāstr, 71: “Masīh ke prem niyam kā dīsrā paks Parosī se prem karnā hai. Parosī kōi amūrt pratyay nahìì, varan ek vāstavik sattā hai. Masīh ne yah ādeśs nahīin diyā ki tū mānavatā athavā manuṣyatā se prem kar. Islie prem kà vișay Parosī hai. Merā Parosī kaun hai? Is praśn kā uttar dete huy masīh ne ek sundar drsțtānt prastut kar Parosī se prem ke samast tatvoin ko pradarśit kiyā hai. Hum aupcārik riśtoì kì duniyà meì rah rahe haim. Arthārt hum yah jānte haim athavā jānne kì kośiś karte haim ki amuk vyakti kyā hai? Athavā kyā kartā hai? . . Uske kitne bacce haim? Vah apnā jīvan kis prakār nirvāh kar rahā hai? Vah kitnā sukhī athavā dukhī ādmī hai? Kyā kō̄ uske ghar meì bìmār hai? Ityādi. Hamārā paricay ek ūprī paricay rabtā hai, arthāt vah kyā kām kartā hai? Aur is drști se hì hamārā aur uskā sambandh judtā hai. Yah durbhāgy kì bāt hai ki hum keval uske ek àyām (dimension) ko hī jānne kā prayās karte haim."

63 Khan, Khristīy Nìtiśāstr, 73-74: “Kucch logoì ko apne gyān, pūimjī, śārīirik sundartā, varg ādi kā ghamand hotā hai aur yah ghamand mānavīy riśtom merì dīvār khad̄i kar detā hai. Ye hamem apne Parosī kī àvaśyakatāom ko dekhne nahìm dete. Bhārat meim varn-ghamand aur kucch paścimī deśom meim ranggarv iske udāharan haim. Khrist ek aur ghamand kī or dhyān ākarsit karte haim jo us kāl kī naitik evam dhārmik avasthā ko dìmak kī bhāinti khāe jā rahā thāa. Vah thā dhārmik ghamand athavā ādhyātmik hone kā garv ... [is dhārmik garv] ko bhārì dhakkā lagāa, jab unhone yah dekhā ki yiśsu to àm logom mein uthtàbaithtā hai; unke sāth khātā-pītā hai aur unko chūtā bhì hai. . . . Khrist ne 'Parosī ke prem' ke ādeś mem is sārì vidhivādì naitikatā kā khandan kiyā, aur us dìvār ko, jo vidhivādì naitikatā dharmī aur adharmī ke bīc khad̄i kartī hai, garīboim aur pāpiyom ke sāth baithkar tod diyā."

64 Khan, Khristīy Nìtiśāstr, 214-215: "Hum masī̄ī jo bhārat mein rabte haim, is bāt ko avaśy dhyān meì rakhem ki bhāratvars yadyapi dharmanirpekș deś hai, tathāpi dharmanirpekșatā kā arth adharm nahìm hai. Pratyek vyakti ko apneapne dharm ke pālan aur prasār karne kì svatantratā hai aur dūsre ke dharm ke prati ādar kā ādeś hai."

65 McGregor, The Oxford Hindi-English Dictionary, 25.

66 Khan, Khristīy Nìtiśāstr, 215: "Hamāre deś kā pratīk hai 'satyamev jayate" arthāt saty $k \bar{\imath}$ hì vijay hai, aur saty $k \bar{a}$ abhiprāy bhāratīy darśan meì iśvar hai... Masīhī ke lie masīh saty hai."

67 Khan presents a non-exclusive decision involving membership in two distinct realms that, Khan argues, should not be mutually exclusive: parameśvar kā rājy and prthvī kà rājy (literally, "Kingdom of God" and "kingdom of earth").

68 Khan, Khristīy Nìtiśāstr, 216-217: "Pablā, ek masīhì ko yah kabkar ki vah parameśvar ke rājy kā sadasy hai rājanìti se bhāgnā nahìn cābie kyomiki vah prthvī ke rājy kā bhì sadasy hai.

Dūsrā, masīhì ko nakārātmak rūp se nāgrik hokar deś meì nahīin rahnā cāhie. Vah keval yahī na kahtā rahe ki deś meì bhraștāaār hai, nyāy durlabh 
hai. Vah iskā doṣ dūsrom par na lagāe, vah svayam bhì doși hai kyomiki vah masīhī prabhāv ko prabhāvakārī karne meì asafal rahā hai.

Tìsrā, use is vicār ko chod denā cāhie ki rājanīti mein kisī prakār kì svacchatā hotī hai, aur ki rājanìti śaitān kì àint hai. Rājanìti svacchatā aur śaitānī kā miśran hai aur masīhì kā yah kartavy hai ki vah rājanīti meri sakriy bhāg lekar subh śakti ko prabal kare.

Cauthā, masīhì kisī pārțī kā mohrā hì na ban kar rahe parantu ek aisā vyakti bane jo apne adhikār aur mat ko masīh kī śikșāom ke anusār vyakt kartā hai.

Pāincvā, use sadā yah nahìm socnā cāhie ki uskā drsțtikon sarvaśresțth hai. Use apnā prabhāv vinamr rūp se dālnā cābie.

Chathvāim, masīhì ko yah nahìim socnā cāhie ki ek hì samasyā ke hul ho jāne se deś kì pratyek samasyā hul ho jāegī. Udāharan ke lie nasbandī, jūāvarjan ityādi. Use jankalyān, nyāy, svatantratā aur surakșā kì bhāvanā ko sadrṛh banāne ke lie sadā prayatnśîl rahnà cāhie."

69 Khan, Khristīy Nìtiśāstr, 234: "Rājanīti memi bhāg lenā kbristīy jīvan kā uttardāyitu hai."

70 Khan, Samvvād, 1: "Vartamān sāmpradāyik, asahiṣnutā, kaț̣artāvād evam rūdhivād vibbhin dharmoin ke anuyāyiyom mem aise bhedabhāu ki bhāvanā ko utpann kar rahā hai jisse ki hamārā āpsī rahan-sahan dūṣit ho gayā hai aur hum ek dūsre ko ghrṇā aur sanśay kī drști se dekh rahe haim. Isī sthiti meim āpsī rahan-sahan hamāre naitik, sāmāijik evam ārthik mūlyom par anucit prabhāv dāl rahā hai. Kucch log dharm kā durupayog kar apne rājanaitik svārth kī pūrti mem lage haim. Sāmpradāyik dange, nity-prati jor pakad rahe haim aur alpasankhyak samudāy bhay ke vātāvaran meì jū rahe haim. Ek dūsre ke dharm ke prati nity nai galatfahmiyom kā pracār kiyā jā rahā hai. Naitik mūly, viśes kar

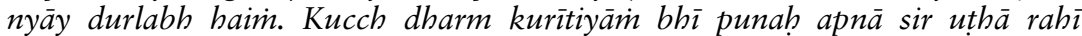
haim. In hālāt mem 'antardhārmik samvād' ek àvaśyakatā bantā jā rahā hai. Is antardhārmik samvād dvārā hum mil julkar naitik patan aur girte hue dhārmik mūlyoì ko samb̄hālne ke lie sāmūhik prayās kar sakte haim. Antardhārmik samvād keval pūrvāgrhoì kā hì unmūlan nahìm parantu vah vibhinn dharmoin ke anuyāyiyom mei் mil-jul kar rahne kì samajh ko badhāvā detā hai. Jaisā hum pīche likh āye haim antardhārmik samvād ek aisī praḱkriyā hai jiske dvārā hum dūsre dharm kì rìtiyoim, mūlyoì evam dhārmik anubhavoin ko samajhne kā prayās karte haim. Yadi iske pīcche ek saccī bhāvanā hai to samast dūriyom kā vilop ho jātā hai aur hum ek dūsre ke itne nikat ā jāte haim ki hummem dabī buī bhrātr bhāvanā punạ jāg jātī hai aur hum ék dūsre ke hāth meì hāth dāl dharm ke us śikhar kī or baḍne lagte haim jahām par manușy aur parameśvar kā milan evam manuṣy aur manuṣy kā milan vāstavikatā meì badal jātā hai."

71 i.e., minority religious communities.

72 Khan, Samvād, 1-2: "Antardhārmik samvād ke kucch śatru bhī haim aur in śatruoì mei் pramukh śatru sāmpradāyikatāvād hai. Sāmpradāyikatāvād kā arth hai rājanaitik lābh ke lie dharm kā durupayog. Antardhārmik samvād kā

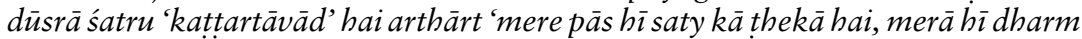
saccā hai aur any dharm śaitān den hai.' Yah unmād ādhyātmik ahankār kī nìnvv par khaḍ̄ hai. Yah ghrṇā ke bīj botā hai aur vibhinn dharmoì ke anuyāyiyom ke mil julkar rahne meì bādhā utpann kartā hai. Antardhārmik samvāa kà tīsrā śatru hamārā agyān hai arthāt ek dūsre ke dharm ke prati hamārā sankucit gyān aur galatfahmiyom athavā tathākathit burāiyom kì apār jānkārī. Jaise

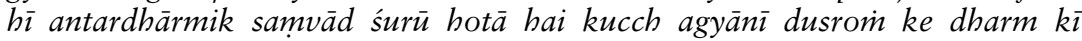
burāiyom kā vyākbyān kar ek aisā prahār śurū kar dete haim jo samvād ko vād-

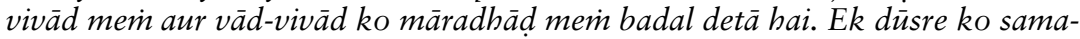
jhane ke sthān par ek dūsre se ghrñā karne lagte haim. Islie jab tak apne dharm aur dūsre ke dharm kà sahì-sahī gyān na ho, samvād apne uddeśy meì vifal ho 
jātā hai. Antardhārmik samvāad kā cauthā mukhy śatru rū dhivād (Fundamental-

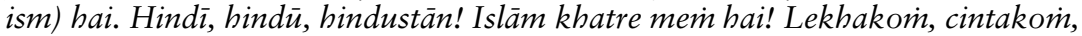
dārśnikom ko dharm, śarīyat ke nām par deś-nikālā denā, maut kā fatvā jārī karnā, yah dhārmik kațtarvād, rū din vāyumandal ko garmā rahe haim. Udhar masī̄i dharm, sikkhdharm, buddh dharm, jain dharm ityādi bhī rūdhivād ke śikār hote jā rahe haim. Bhārat-

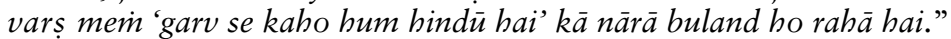

73 Khan, Samvvād, 2: "Is yug mem antardhārmik samvād kì atyant āvaśyakatā hai. Śāyad in samvādoin ke dvārā hì hum vah ekatā jo hum kho cuke haim vāpas pā lemi. Dhārmik kurītiyāim jo apnā sir uthā rahì haim unkā unmūlan kar sakeì. Mil-julkar girte hue naitik, sāmājik mù̆lyom kā bacāv kar sakemi. Sāmājik jīvan bhay se mukt kar sakeim aur ek dharm viśvāsī, dīsre dharm viśvāsī kī nissvārth kalyān kì kāmnā kar sakeì.

Bhàrat vars bahu samudāy, bahu jāti evam bahudharmoin kā ek jītā jāgtāa udāharan hai kintu yah bahuvād anekatā meri ekatā aur ekatā meì anekatā $k \bar{a}$ darśan ubharte hue sāmpradāyikatāvād mei் ek thothā sā niyam pratìt hone lagā hai. Anekatā, ekatā kī or to nahìim le jā rahī varan vah hameim vibhājan kì or le jā rahī hai. Prati din hum ek dūsre ke lie ajnabì bante jā rahe haim. Rājanìti ne dharm ko dūṣit kar use apne lakșy se bhațā diyā hai. Deś meri ghațtī hū̄ in vartamān paristhitiyom ko dekhkar antardhārmik samvād kī āvaśyakatā hai jahāim hum bade khule dimāg se aur ek dīsre ke dharm ke prati sakārātmak ravaiyā apnāte hue aur katutāa aur vișamatā ko man se dūr karte bue, un samast galatfahmiyom ko dīr karem aur yah svīkār karem ki rājanaitik evam ārthik läbhom ke lie dharm kā upayog ati nindanìya hai. Dharm manușy ko apne kartavyom kā pālan sikhātā hai, viśeșakar ve kartavy jo manuṣy ko ìsvar se jodte haim aur uski à àtmā meì śānti aur ànand ko bhar dete haim aur manusy is sansār

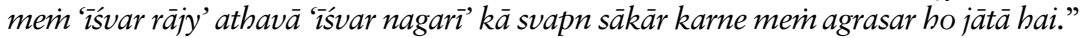

74 Which he described in Life Together (orig. German 1938). For an introduction to the experiment, see Bonhoeffer, Life Together, 10-11 and Metaxas, Bonhoeffer, 262-277.

75 Biography from Dayal, Uttar Bhārat, iv-v and Dayal, Masīhī Dharm Vijñān, iv-v.

761951 election results at www.elections.in/parliamentary-constituencies/1951election-results.html (accessed 24 July 2015).

77 Anand's "brief introduction of the author," in Dayal, Uttar Bhärat, iv.

78 Dayal, Masīhī Dharm Vijūān, 29-30: "Prabhu yeśu kā śubh samācār kisī viśeș sabhyatā ko sthāpit karne ke lie nahìm hai balki śubh samācār manuṣy ke uddhār ke lie hai. Sabhyatā aur sanskrti kà nirmān manuṣy ke hāth meỉ hai. Nissandeh masīhīyat namak ke samān hai. Islie masīhī jan ke viśvās kā prabhāv sanskrti par paḍnā anivāry hai. Masīhīyoṁ kā kartavy hai ki ve apne samāj aur rāṣtr ke sandarbh meì sanskrti ke nirmān meì yogdān dem. Masīhìyom ke pās sanskrti ke lie kō̄ masìhī yojanā nahìm hai."

79 Dayal, Masīhī Dharm Vijñān, 187: “Praśn hai ki kyā parameśvar ke rājy kā hamāre dharm nirpeks evam ārthik aur vaigyānik unnati ke kāl meì mahatv rah gayā hai? Uttar hai, hāim. Śānti kì lālsā hameśā se rahī hai. . . . Sansār meim lad̄aiyom aur bhayaìkar hathiyārom kā ant nahìm huā hai. Kyā anyāy, garībì, śoșan, bhayà̉kar bìmāriyām khatm ho gaī haim? . . . Khrist ke śubhsandeś ko hameì vartamān sansār ko sunānā hai."

80 Dayal, Masīhī Dharm Vijñān, 28-29: "Anekavād (Pluralism) sanskrti kī mahatvapūrn viśiștatā hai. Islie sanskrti ke sāmne bahut sī mānyatāom ko svīkār karne kì cunautì rabtī hai. Ko $\bar{\imath}$ bhì samāj sāre gunoì ko cāhne ke bāvajūd unhem prāpt nahìm kar saktā. Samāj kī mānyatāem anek haim, kyờki manuṣy anek haim aur unke uddeśy aur àvaśyakatāem anek haim. . . . Anekavādì samāj mei் parameśvar kā rājy, prabhu yeśu masīh, pitā parameśvar aur śubhasamācār 
ye bāteim masīhī viśvāsiyom ke lie bahut hì mahatvapūrn mānyatāem haim. Kintu ye keval masīhìom ke lie mahatvapūrn haim."

81 Dayal, Masīhī Dharm Vijñān, 22: "Ek vyakti dūsre vyakti ko pūrn rūp se jān [nahìin] saktā hai jab tak dūsrā vyakti svayam apne bāre meì na batāe. . . . Parameśvar svayam apne ko prakat kartā hai. Vah apnī sāmarthy aur svabhāv ko prakaț kartā hai. Parameśvar hì sāre jagat aur sāre dharmoin ke logoì par svayam prakat huā hai. Isīlie sabhī dharmom ke anuyāyì kahte haim ki parameśvar hai. Yah bāt alag hai ki parameśvar ke vișay mein viśvāsom memi bhinnatā hai. Adhiktar hindū anek devī-devatāom ko mānte haim. Kintu inke samarthak vicārasīl hindū kabte haim ki sāre devī-devatā ek hīìsvar kī śakti haim. Islie ve

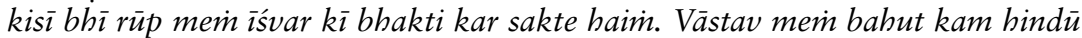
nirgun brahm kī Ārādhănā karte haìm. .. . Islām meì allāh ke anek sundar nām haim jinse uske gunom kā sanket hotā hai. Allāh sarvaśaktimān aur nyāyapūrn hai. Anek dārśanik kahte haim ki param tatv samast prāniyoì kā mūl àdhār haim. Vah hamāre sarvocc naitik aur bauddhik ākāìksāom kà strot hai. Vah sajīu śakti hai jo samast srssti ko sancālit aur ākarșit kartī hai."

82 Dayal, Masīhī Dharm Vijñān, 127: "[Manuşy ke] buddhi aur vivek meim parameśvar kā svarūp hai. Yadi parameśvar aur manușy meì samāntā nahīì hotī to donom meim sangati sambhav nahìm hotì. Parameśvar svayam ko manușy par prakaț nahìim kartā yadi manuṣy mem parameșvar ko samajhane aur usse sañgati karne kì ksamatā na hotī."

83 Howell was ordained by the Evangelical Church of India. From 1990-1996 he served as the Principal of Allahabad Bible Seminary and from 1996-1997 as the Associate General Secretary of E.F.I. He was elected General Secretary of E.F.I. in May 1997. He has also served as the Secretary of the Evangelical Fellowship of Asia, Member of the Continuation Committee of the Global Christian Forum, and Vice-Chairperson of the International Council of the World Evangelical Alliance. Howell's works include Free to Choose and Transformation at Work (both in English) and Mission (in Hindi). He also serves as the chief editor of Aim, the monthly newsletter of E.F.I. (Biographic details from Howell, Parivartan)

84 Howell, Parivartan, 7: "Bāibal hamein parameśvar kì kahānì batātī hai. Ye parameśvar kī aur uski khoì huī srsți evam use punahsthāpit karne kì kahānī hai."

85 Howell, Parivartan, 10: "Islie bäibal kā àrambh isī vicār ke sāth hotā hai ki parameśvar ek srot ke rūp meim, sambandh ek präthamikatā ke rūp meì aur parameśvar ek adhikārī ke rūp meì hai."

86 Howell, Parivartan, 11-12: "Is bad̄i tasvīr meì hamārā niyantran sìmit haibalki sac kaheì to hamārā niyantran thā hì nahìm. Parantu apne vyavahār par hamārā niyantran avaśy hai aur hamem apne vyavahār par niyantran rakhnā bhī cāhie. Parameśvar kì bhūmikā us badì tasvīr ko niyantran meì hai aur hamārì bhümikā svayam ko aur apnī jimmedāriyom ko niyantran meì rakhnā hai. Kahne kà tātpary yah hai hameì 'àtm-niyantran' banāe rakhnā hai."

87 Howell, Parivartan, 18: "Bāibil kì is pūrì kahānī meim hamāre jīvan kā ucit sthān kyā hai, aur parameśvar is samsār mem kyā kucch kar rahā hai is bāt kā hameim jūān prāpt karnā hai. Hamem apne sangharșom se àge barhnā hai aur parameśvar ke us vrhad aur ba d̄i yojanā mein hamārà sthān evam bhümikā kyā hai isko jānnā hai. Parameśvar se kahie ki ve āpko jūvan ke in viṣayom ko jānne aur dekhne mein āpki madad kareim."

88 Howell, Parivartan, 15: 


\begin{tabular}{|c|c|}
\hline Parameśvar & Manuṣy \\
\hline Parameśvar srot hai & Hum parameśvar par nirbhar haim \\
\hline Parameśvar racayitā hai & $\begin{array}{l}\text { Hum racnā hai aur uske binā vidvān } \\
\text { nahìim rah sakte }\end{array}$ \\
\hline $\begin{array}{l}\text { Parameśvar ke pās samsār kāa adhikār } \\
\text { hai aur vah us par niyantran kartā hai }\end{array}$ & $\begin{array}{l}\text { Hum svayam-kendrit hai arthāt apne } \\
\text { ko niyantrit kar sakte haim }\end{array}$ \\
\hline $\begin{array}{l}\text { Parameśvar jindagiyom kà nyāy karne } \\
\text { vālà hai }\end{array}$ & Hum jīvan kā anubhav karte haim \\
\hline $\begin{array}{l}\text { Parameśvar ne manuṣy kì racnā kī aur } \\
\text { uske lie niyam banāem }\end{array}$ & $\begin{array}{l}\text { Hum parameśvar dvārā batāe } \\
\text { niyamoi் kā apnī jindagiyom meim } \\
\text { pālan karte haim. }\end{array}$ \\
\hline
\end{tabular}

89 Howell, Parivartan, 252: “Bhāratīy prajātantr nā cunautiyoì kā, sāmudāyik sanghars, ātankvād se larnā, yuvā samāj kì vicārdhārāom ke sāth calnā, in sabkā sāmnā kartā hai. Bhārat ko apnī paddhatī ko behtar banāne kī àvaśyakatā hai. Iskā arth prajātantr ko nirnay lenevālā, prabhāvī, samvidhānātmak, svatantratāvād ko

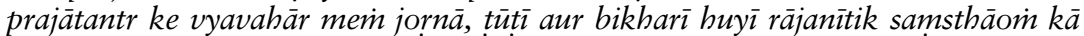
purnnirmān karnā aur sabse badhkar sarkārì samsthāom tathā sattādhāriyom ko apnī jimmevārì samajhnā aur use nibhānà atyant àvaśyak hai. Unhem keval kānūnī nahìm parantu naitik bātoi் kā udāharan logoì ke sāmne rakhnā cāhie aur uskā svayam pālan karnā cāhie. Iske bagair prajātantr khokhlā ban jāegā, keval akșam bì nahìim parantu khatarnāk bhī, iske sāth svatantratāvād nașt ho jāegā, svatantratā kà upayog atyācār ke lie kiyā jāegā aur sāmāny jan jīvan nașt ho jāegā."

90 Howell, Parivartan, 252-253: "Masīhiyom kā rājanīti ke kṣetr se hat jāne kā arth hai ki galat rìti se vartamān meì sthit sāmājik-rājanītik drstikon ko svīkār karnā. Kucch viśișt yojanāom aur anyāy ke viruddh yadi di்ärmik pratirodh nahìm kiyā gayā to vāstav meì hum unko sahmatī dete haim. Deś ke rājanìtik kāryoi் meim sahbhāg denā yah masīhiyom kā kartavy hai, tāki ve apne drștikon ko

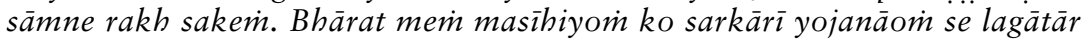
takkar len̄̄ pad rahī hai. Iskā ek choțā udāharan hai, cār rājyoì meì dharm sambandhi bil kì manjūrī pradān karnā. To fir ab hamāre sāmne kyā mārg hai, rājanìti meì masīhiyoì kà adhik sahyog yā fir rājanīti se pūrn rūp se dūr rahnā?

Masīhi viśvās - dharm ke nijīkaran ke, dharm ko simit karne, aur use keval jīvan ke āntarik kșetr tak hì rakhne, kà virodh kartā hai. Dharm nij̄ nabìm ho saktā, dharm kisì ek vyakti kā yā samudāy kà honā cāhie. Dharm sadaiv anek sāmājik tathā āpsī sambandho kī jimmedārī meì śāmil hotā jātā hai."

91 Howell, Parivartan, 253: "Parameśvar ke rājy ko mānavatā mei் mel-milāp karnā, śānti lānā prajātantr kā vistār karnā yā sāmājik tathā vyāvasāyik svatantratā lāne tak sìmit nahīin karnā cāhie. Pavitr śāstr kisī ek viśișt prakār kī sarkār kī bāt nahīin kartā hai. Rājanìti ke sabhī prakāroì kā durupayog kiyā jā saktā hai. Agar jimmedār prajātantr rājanìti ke apne nirnayoì kī rakșā kar saktā hai, to vah arājakatā ko nașt bhī kar saktā hai. Masīhiyom ko do gambhīr galtiyoì se backar rahnā cāhie: pahlī bāt yah kì yojanā yā paddhatī ke badalne se samsār nae samāj yā parameśvar ke rājy memi badlā jā saktā hai aur dīsrī yah kī sāmājik-rājanìtik paddhati yā yojanāem vikasit karnā mahattvapūrn nahìì hai kyoìki hameì susamācār pracār karne ke lie bulāyà gayā hai."

92 Howell, Parivartan, 254: "Masīhì log, nāgarik hone ke nāte apne Parosī kì tathā rāșț kì cintā karne ke dvārā parameśvar ke rājy kī sevā karte haim. Parivartan lāne vālā miśan vāstav meì sāmājik burāī hațāne tathā samāj mein parameśvar ke rājy ke mülyoin ko lāne ke lie pavitr śāstr ke drșțikon kā upayog kartā hai." 
93 Howell, Parivartan, 271: "Jab carcā kā vișay mānavìy jimmedārī kī or jātā hai tab log aksar becain ho jāte hai. Pavitr śāstr dūsromi ke adhikārom ke lie sangharș karne ke vișay mem bahut kucch kahtā hai, parantu apne adhikārom ke lie sangharș karne ke vișay mem bahut thợā batāyā gayā hai. Dūsrī or jab vah hamāre vișay mem kahtā hai to hameim apne adhikārom ke vișay mem nabìm parantu jimmedāriyom ke vișay meim batātā hai. Hamei் parameśvar tathā apne Parosī se prem karne ke lie kahā gayā hai. Pavitr śāstr is bāt par jor detā hai ki dī̄sre vyakti ke adhikārom kī rakșā karnā hamārī jimmedārī hai; aur aisā karne ke lie hameì adhikār bhī chorne ke lie taiyār rahnā cāhie.

Hamem is bāt ko svīkār karnā cāhie ki dūsre logoin ke adhikār hamārī jimmedārī hai. Sthānīy kalīsiyā kā jīvan parameśvar ke rājy ko pragaț karne ke lie hai. Kalīsiyā ko samsār meì ek samudāy ke rūp meì rahnā cāhie jahāin mānav sammān aur samānatā ko sadaiv sthān diyā jātā hai, aur logoin kī ek dūsre ke prati jimmedārī ko svīkār kiyā jātā hai jismeim kōi bhedbhāv nahìm, pakșpāt nahīim, jahāim garīb aur kamjorom ke lie sangharș kiyā jātā hai aur mānav ko mānav bankar rahne kā adhikār hai, thīk usī prakār jis prakār parameśvar ne unheì banāyà aur cāhā ki ve usì prakār raheì."

94 Howell, Parivartan, 272: "Parameśvar ne jin logoì ko cunā aur bulāyā hai unke any logom ke sāth sambandh meim masīh samudāy kä bhinn caritr va svabhāv dikhāì detā hai. Kalīsiyā parameśvar ke log haim, yah masīh kā śarìr aur dulhan hai aur pavitr àtmā kā mandir hai. Jāgarūk kalīsiyā sampūrn rìti se ek parivār hai jo viśvās kā parivār hai. Aur jaise humne pable hī carcā kì hai masīh ke samudāy ko bhinn samskrti ko pragat karnā cāhie. Parameśvar ke bulāe hue log hone ke nāte kalīsiyā kī ek jimmedārī hai-cinh honā, aur parameśvar ke rājy kā sādhan bannā. Iskā arth yah huā ki yah samudāy parameśvar ke āne vāle rājy kī or iśārāa kartā hai. Pavitr àtmà se parī̄ūrn samudāy hone ke nāte, kalìsiyā ko apne sāmāny jīvan ke dvārā bhī parameśvar ke āne vāle rājy ko pragat karnā cāhie. Masīh kāa samudāy hone ke nāte kalīsiyā ko us àne vāle rājy ko samsār meì vāstavik rūp mem pradarśit karnā cāhie, kyomki vah rājy vyakti jīvan kī pürnatāa aur samāj ke lie nyāy aur sampūrn srsțti ke lie àrogyatā pradān kartā hai."

95 Howell, Parivartan, 171. "Hum bhārat ke bāhar sthit kalīsiyāom se kahnā cābte haim ki ve is bāt ke vișay mem sacet rahem ki miśan kì ayogy bhāsāa ke prayog ke kāran ve yahāim any viśvās ke logom kī bhāvanāom ko hì keval thes

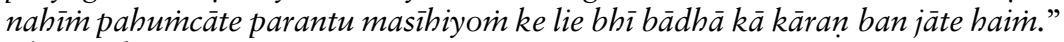

96 Khan, Khristīy Nìtiśāstr, 214.

97 Or, the rule of one party, person, or institution. See Bahri, Rājpāl Hindì Śabdakoś, 128.

98 Khan, Khristīy Nìtiśāstr, 214: “Vah rājy jo parameśvar kī ājñāomi kī avahelanā kare, uskā virodh karnā masīhī naitikatā hai, aur jo rājanīti ekādhikār kī or ludhak rahī ho usko sìdhe mārg par lānā masīhiyom kà uttardāyitv haim."

99 Dayal, Masīhī Dharm Vijñān, 30.

100 Howell, Parivartan, 271.

1 Manorama, "Dalit Women: The Thrice Alienated." Manorama has studied the exceptional impact of discrimination on the women of backward communities and has described such women as the "Dalits among the Dalits."

2 Melanchthon, "A Dalit Reading of Genesis 10-11:9." Melanchthon is currently an associate professor of Old Testament at the University of Divinity in Australia. She formerly taught at Gurukul Lutheran Theological College and Research Institute, Chennai, and was a member of the Senate of Serampore College, Serampore. She has written extensively on the intersection of Dalit studies, gender, and biblical interpretation. 
3 Shiri, The Plight of Christian Dalits. Shiri's work has drawn attention to the reality of caste-discrimination within churches in India by shedding light on caste relations within Indian churches.

4 Larbeer, "The Story of the Dalits of India." Larbeer's work has reminded us of the continuing mistreatment of backward Christians as people who are still socially ostracized, subjected to violence, deprived of their rights, exploited for cheap labor, and denied justice and denied the equal protection of the State.

5 Harper, In the Shadow of the Mahatma, 355-357.

6 On 'vedantic' Christianity, see Ganeri, "Catholic Encounter with Hindus," 415-418.

7 Tharamangalam, "Whose Swadeshi?" 232-246.

8 Ganeri, "Catholic Encounter with Hindus," 426-427.

9 In the works of Dayal, James, Khan, and Howell discussed earlier.

10 In the works of Jonathan and Khan discussed earlier.

11 In the works of James and Howell discussed earlier.

12 In the work of Howell discussed earlier.

13 In the works of Anand, Dayal, Howell, James, Khan, Lall, and Paul discussed earlier.

14 Jain, "From Kil-Arni to Anthony," 17.

15 McGregor, The Oxford Hindi-English Dictionary, 66.

16 Anand, in a "Personal Request to Readers" (dated 2009) in Khan, Khristīy Nìtiśāstr, iv: "Ham āpse nijī nivedan karnā cāhte haim ki jab ye pustakemin prakāśit

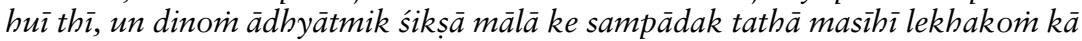
dhyān bhāṣā aur samskrti jaise mahatvapūrn praśn kī or nahīin gayā thā, aur unhoinne masīhi dharm ke samsthāpak prabhu yeśu, evam masīhī dharmguruom, nabiyoìn, preritom àdi ke lie bhäratīy samskrti ke anukūl, ādarsūcak sarvanām kā prayog nahīin kiyā thā, jiske kāran carc meim āj bhī 'yeśu bulātā hai', 'yeśu kahtā hai' jaise aśișt sambodhan prayukt kie jāte haim."

17 Yagi, "Christ and Buddha"; Pieris, "The Buddha and the Christ."

18 Khan, Khristīy Nìtiśāstr, 216-217.

19 James, Mahilā Dharmavijūān, 108.

20 Khan, Bīsvìm Śatābdī ke Pramukh Dharmavijñānī, xi: "Pratham prayās mem sadaiv kuch kamiyāim, aur truțiyāim rah jātī haim. Pāthak evam ālocak in kamiyom aur truțiyom ko najarand $\dot{\bar{j} j}$ karte huye us sāmagrì se läbh uthāyenge jo is pustak kà tānà bānā hai. Ālocakom aur pāthakoì kā yah bhì kartavy hotā hai ki pustak ki kamiyom aur trutiyom ko lekhak tak pahumcāyem tāki vah dvitīy samskaran mem in ko dūr kar sake." McGregor suggests "warp and woof" to translate 'tānā bānā.' McGregor, The Oxford Hindi-English Dictionary, 448. "Warp and woof" captures the intent of the phrase, which is to point the reader to the 'heart of the matter.'

21 King, One Language, Two Scripts, 15.

22 King, One Language, Two Scripts, 16.

23 King, One Language, Two Scripts, 17.

24 King, One Language, Two Scripts, 8.

25 King, One Language, Two Scripts, 129.

26 King, One Language, Two Scripts, 9.

27 King, One Language, Two Scripts, 129.

28 King, One Language, Two Scripts, 153.

29 King, One Language, Two Scripts, 29.

30 King, One Language, Two Scripts, 131; original emphasis.

31 King, One Language, Two Scripts, 134.

32 King, One Language, Two Scripts, 134.

33 King, One Language, Two Scripts, 134.

34 King, One Language, Two Scripts, 137. 
35 King, One Language, Two Scripts, 139-142.

36 King, One Language, Two Scripts, 148.

37 King, One Language, Two Scripts, 175.

38 King, One Language, Two Scripts, 177.

39 King, One Language, Two Scripts, 177.

40 King, One Language, Two Scripts, 177.

41 Van der Veer, Religious Nationalism, 166.

42 D'Sa, "Christian Incarnation and Hindu Avatara."

43 Panikker, The Unknown Christ of Hinduism.

44 Clooney, Hindu God, Christian God.

45 Bauman, Pentecostals, 140.

46 Bauman, Pentecostals, 135.

47 Bauman, Pentecostals, 37.

48 Duff, India, and India Missions, 517. Emphasis added.

49 Yelle, The Language of Disenchantment, 85.

50 Ward, A View of the History, ciii; cited in Yelle, The Language of Disenchantment, 101.

51 Ward, A View of the History, xcvii-xcix.

52 Altman, Heathen, Hindoo, Hindu.

53 Ward, A View of the History, lxxx. Emphasis added.

54 Ward, A View of the History, ciii.

55 Duff, India, and India Missions, 129; see also Yelle, The Language of Disenchantment, 148-149.

56 Williams, Original Papers, 254-255.

57 Williams, Original Papers, 257.

58 Ward, A View of the History, lxxxvii-lxxxviii.

59 Duff, India, and India Missions, 556-559.

60 Duff, India, and India Missions, 556.

61 Duff, India, and India Missions, 558.

62 Duff, India, and India Missions, 559.

63 Duff, India, and India Missions, 560.

64 Duff, India, and India Missions, 557.

65 Duff, India, and India Missions, 274-276.

66 Duff, India, and India Missions, 596.

67 Williams, Original Papers, 269.

68 Williams, Original Papers, 264-265.

69 Lalhmangaiha, Holistic Mission, 88-94, 132-135.

70 Sugirtharajah, The Bible and the Third World; Yelle, The Language of Disenchantment.

71 King, One Language, Two Scripts, 199.

72 King, One Language, Two Scripts, 123.

73 King, One Language, Two Scripts, 127.

74 Mankekar, "Epic Contests."

75 King, One Language, Two Scripts, 131.

76 Van der Veer, Religious Nationalism, 10.

77 Prasad, quoted from King, One Language, Two Scripts, 131.

78 King, One Language, Two Scripts, 137.

79 King, One Language, Two Scripts, 144-145.

80 King, Nehru and the Language Politics of India, 55-57, 60.

81 Dalmia, The Nationalization of Hindu Traditions, 146-221.

82 Pandey, The Construction of Communalism, 216.

83 King, Nehru and the Language Politics of India, 70-73. 


\section{References}

Amaladoss, Michael. "Foreword 1." In Asian Christian Theologies: A Research Guide to Authors, Movements, Sources. Volume 1: Asia Region 7th-20th Centuries; South Asia; Austral Asia, edited by John C. England, Jose Kuttianimattathil, John Mansford Prior, Lily A. Quintos, David Suh Kwang-sun, and Janice Wickeri. Delhi: Indian Society for Promoting Christian Knowledge, 2002.

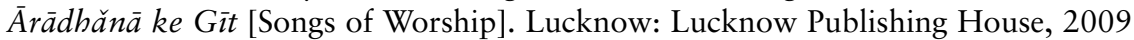
[1975].

Arokiasamy, Soosai. Dharma, Hindu and Christian, According to Roberto de Nobili: Analysis of its meaning and its use in Hinduism and Christianity. Rome: Editrice Pontificia Universita Gregoriana, 1986.

Assmann, Jan. Monotheismus und Kosmotheismus: Ägyptische Former eines 'Denkens des Einen' und ibre europäische Rezeptionsgeschichte. Heidelberg: Winter, 1993.

Banerjee, Krishna Mohan. The Relation Between Christianity and Hinduism. Papers for Thoughtful Hindus. Madras: The Christian Literature Society, 1892.

Bartley, Christopher J. The Theology of Rāmānuja: Realism and Religion. London: Routledge, 2002.

Bauman, Chad M. Pentecostals, Proselytization, and Anti-Christian Violence in Contemporary India. New York: Oxford University Press, 2015.

Bauman, Chad M. and Richard Fox Young, eds. Constructing Indian Christianities: Culture, Conversion and Caste. New Delhi: Routledge, 2014.

Blumhardt, James Fuller. Catalogues of the Hindi, Panjabi, Sindhi, and Pushtu Printed Books in the Library of the British Museum. London: British Museum, 1893.

Bowen, John R. Religion in Practice: An Approach to the Anthropology of Religion, fourth edition. Boston: Pearson, 2008.

Boyd, Robin H.S. An Introduction to Indian Christian Theology. Madras: The Christian Literature Society, 1975 [1969].

Boyd, Robin H.S. Bhārat mem Masīhī Dharmavijñān [An Introduction to Indian Christian Theology]. Jabalpur: Hindi Theological Literature Committee, 1976 [1969].

Carey, Eustace. Memoir of William Carey. London: Jackson and Walford, 1836.

Carey, William. 'Journal.' Regent's Park College, Oxford: Angus Library and Archive, 1795.

Chakrabarty, Dipesh. Provincializing Europe: Postcolonial Thought and Historical Difference. Princeton: Princeton University Press, 2000.

Chatterji, Suniti Kumar. Indo-Aryan and Hindi: Eight Lectures, On the History of the Aryan Speech in India and on the Development of Hindi (Hindusthani) Delivered before the Research \& Post-Graduate Department of the Gujarat Vernacular Society in 1940. Ahmedabad: Gujarat Vernacular Society, 1942.

Clarke, Sathianathan. Dalits and Christianity: Subaltern Religion and Liberation Theology in India. New Delhi: Oxford University Press, 1998.

Conference on Urdu and Hindi Christian Literature held at Allahabad, 24th and 25th February, 1875. Madras: The Christian Vernacular Education Society, 1875.

Dalmia, Vasudha. The Nationalization of Hindu Traditions: Bhāratendu Hariśchandra and Nineteenth-Century Banaras. Ranikhet: Permanent Black, 2010 [1997]. 
Dandekar, Deepra. "Pilgrimage, Authority and Subversion: Anonymous Marathi Christian Didactic Literature in Nineteenth Century India." Zeitschrift für Indologie und Südasienstudien 35 (2018): 39-60.

Dandekar, Deepra. The Subhedar's Son: A Narrative of Brahmin Christian Conversion from Nineteenth-Century India. New York: Oxford University Press, 2019.

Das, Sisir Kumar. Sahibs and Munshis: An Account of the College of Fort William. New Delhi: Orion Publications, 1978.

Dempsey, Corinne G. "Lessons in Miracles from Kerala, South India: Stories of Three 'Christian' Saints." In Popular Christianity in India: Riting Between the Lines, edited by Selva J. Raj and Corinne G. Dempsey. Albany: State University of New York Press, 2002.

Doniger, Wendy. The Hindus: An Alternative History. New York: Penguin Books, 2009.

Eck, Diana L. Banaras: City of Light. New York: Columbia University Press, 1999 [1982].

Eck, Diana L. Darśan: Seeing the Divine Image in India. New York: Columbia University Press, 1998.

England, John C., Jose Kuttianimattathil, John Mansford Prior, Lily A. Quintos, David Suh Kwang-sun, and Janice Wickeri, eds. Asian Christian Theologies: A Research Guide to Authors, Movements, Sources. Volume 1: Asia Region 7th20th Centuries; South Asia; Austral Asia. Delhi: Indian Society for Promoting Christian Knowledge, 2002.

Ernst, Carl W. Following Muhammad: Rethinking Islam in the Contemporary World. Chapel Hill: The University of North Carolina Press, 2003.

Evans, Thomas. Kaise Pāyā Muktidātā, Bhayaharn Dās kā Itihās [How I Found the Savior, or the Shepherd Convert of Monghyr]. Benares: Medical Hall Press, 1877.

Flood, Gavin. An Introduction to Hinduism. Cambridge: University of Cambridge Press, 1996.

Fox, Richard G. "Hindu Nationalism in the Making, or the Rise of the Hindian." In Nationalist Ideologies and the Production of National Cultures, edited by Richard G. Fox. Washington, D.C.: American Anthropological Association, 1990.

Hakala, Walter N. Negotiating Languages: Urdu, Hindi, and the Definition of Modern South Asia. New York: Columbia University Press, 2016.

Hansen, Kathryn. Grounds for Play: The Nautanki Theatre of North India. Berkeley: University of California Press, 1992.

Hasan, Mushirul. "The Myth of Unity: Colonial and National Narratives." In Contesting the Nation: Religion, Community, and the Politics of Democracy in India, edited by David Ludden. Philadelphia: University of Pennsylvania Press, 1996.

Hawley, John S. Three Bhakti Voices: Mirabai, Surdas, and Kabir in Their Time and Ours. New Delhi: Oxford University Press, 2005.

Hawley, John. S. and Mark Juergensmeyer. Songs of the Saints of India. New Delhi: Oxford University Press, 2004 [1988].

Hooper, David, ed. A Welshman in India: A Record of the Life of Thomas Evans, Missionary. London: James Clark \& Co., 1908.

Hopkins, Steven P. Singing the Body of God. New York: Oxford University Press, 2002.

Horstmann, Monika, ed. Bhakti in Current Research, 2001-2003. New Delhi: Manohar Publishers, 2006. 
Israel, Hephzibah. Religious Transactions in Colonial South India: Language, Translation, and the Making of Protestant Identity. New York: Palgrave Macmillan, 2011.

Israel, Hephzibah. "Authority, Patronage and Customary Practices: Protestant Devotion and the Development of the Tamil Hymn in Colonial South India." In Constructing Indian Christianities: Cultures, Conversion and Caste, edited by Chad M. Bauman and Richard Fox Young. New Delhi: Routledge, 2014.

Jonathan, Franklin C. Biśap: Dāyitv, Darśan aur Mūly [Bishop: Vocation, Vision and Value]. Jabalpur: Hindi Theological Literature Committee, 1994.

Jones, Arun W. Missionary Christianity and Local Religion: American Evangelicalism in North India, 1836-1870. Waco: Baylor University Press, 2017.

Khalidi, Omar. "Hinduising India: Secularism in Practice." Third World Quarterly 29, no. 8 (2008): 1545-1562.

Khan, Benjamin. Bìsvìm Śatābdì ke Pramukh Dharmavijñān̄ [Major Christian Theologians of the Twentieth Century]. Jabalpur: Hindi Theological Literature Committee, 1990.

King, Christopher R. One Language, Two Scripts: The Hindi Movement in Nineteenth Century North India. Delhi: Oxford University Press, 1994.

KPMG in India and Google. "Indian Languages - Defining India's Internet: A Study by KPMG in India and Google.” April 2017. Accessed at https://assets.kpmg/ content/dam/kpmg/in/pdf/2017/04/Indian-languages-Defining-Indias-Internet. pdf.

Kulandran, Sabapathy. "Christian Faith and Hindu Bhakti." Indian Journal of Theology 6, no. 4 (October-December 1957): 118-121.

Kunnatholy, Abraham. St. Thomas' Christians in Madhya Pradesh: A Historical Study on Apostolic Church of St. Thomas. Bangalore: Asian Trading Corporation, 2007.

Lipner, Julius J. The Face of Truth: A Study of Meaning and Metaphysics in the Vedāntic Theology of Rāmānuja. Albany: State University of New York Press, 1986.

Lumbard, Joseph. "The Quranic View of Sacred History and Other Religions.” In The Study Quran, A New Translation and Commentary, editor-in-chief Seyyed Hossein Nasr. New York: HarperOne, 2015.

Malik, Keshav. Hindi Poetry Today. New Delhi: Indian Council for Cultural Relations, 1985.

Malinar, Angelika. The Bhagavadgītā: Doctrines and Contexts. New York: Cambridge University Press, 2007.

Masica, Colin P. The Indo-Aryan Languages. Cambridge: Cambridge University Press, 1991.

Massey, James. Dalits in India. Delhi: Indian Society for Promoting Christian Knowledge, 1995.

Massey, James, ed. Indigenous Peoples, Dalits: Dalit Issues in Today's Theological Debate. Delhi: Indian Society for Promoting Christian Knowledge, 1998.

McGregor, Ronald S. "The Rise of Standard Hindi and Early Hindi Prose Fiction." Journal of the Royal Asiatic Society of Great Britain and Ireland, no. 3/4 (October 1967): 114-132.

McGregor, Ronald S. Hindi Literature of the Nineteenth and Early Twentieth Centuries. Wiesbaden: Otto Harrassowitz, 1974. 
McGregor, Ronald S., ed. The Oxford Hindi-English Dictionary. New Delhi: Oxford University Press, 1993.

McGregor, Stuart. "The Progress of Hindi, Part 1: The Development of a Transregional Idiom." In Literary Cultures in History: Reconstructions from South Asia, edited by Sheldon Pollock. Berkeley: University of California Press, 2003.

Monier-Williams, Monier. A Sanskrit-English Dictionary, Etymologically and Philologically Arranged, with special reference to Cognate Indo-European Languages. Delhi: Motilal Banarsidass Publishers 2005 [1899].

Mosse, David. The Saint in the Banyan Tree: Christianity and Caste Society in India. Berkeley: University of California Press, 2012.

Narayanan, Vasudha. "Afterword: Diverse Hindu Responses to Diverse Christianities in India." In Popular Christianity in India: Riting Between the Lines, edited by Selva J. Raj and Corinne G. Dempsey. Albany: State University of New York Press, 2002.

Nasr, Seyyed Hossein, editor-in-chief. The Study Quran, A New Translation and Commentary. New York: HarperOne, 2015.

Office of the Registrar General \& Census Commissioner, India. "Statement-1: Abstract of Speakers' Strength of Languages and Mother Tongues - 2011.” Ministry of Home Affairs, Government of India, 2018.

Office of the Registrar General \& Census Commissioner, India. "Statement-5: Comparative Speakers' Strength of Scheduled Languages - 1971, 1981, 1991, 2001 and 2011." Ministry of Home Affairs, Government of India, 2018.

Office of the Registrar General \& Census Commissioner, India. "Statement-7: Growth of Scheduled Languages - 1971, 1981, 1991, 2001 and 2011.” Ministry of Home Affairs, Government of India, 2018.

Office of the Registrar General \& Census Commissioner, India. "Part-A: Distribution of the 22 Scheduled Languages-India/States/Union Territories - 2011 Census.” Ministry of Home Affairs, Government of India, 2018.

Orsini, Francesca. The Hindi Public Sphere 1920-1940: Language and Literature in the Age of Nationalism. New Delhi: Oxford University Press, 2009 [2002].

Orsini, Francesca, ed. Before the Divide: Hindi and Urdu Literary Culture. New Delhi: Orient BlackSwan Private Limited, 2010.

Pandey, Gyanendra. The Construction of Communalism in Colonial North India, third edition. New Delhi: Oxford University Press, 2006 [1990].

Pavitr Bāibil, arthāt Purānā aur Nayā Dharm Niyam [Holy Bible, i.e., the Old and New Religious Testaments]. Bangalore: Bible Society of India, 2004.

Pinch, Vijay. "Bhakti and the British Empire." Past \& Present 179 (May 2003): 159-196.

Pollock, Sheldon. The Language of the Gods in the World of Men: Sanskrit, Culture, and Power in Premodern India. Berkeley: University of California Press, 2006.

Raghavendra, M.K. The Politics of Hindi Cinema in the New Millennium: Bollywood and the Anglophone Indian Nation. New Delhi: Oxford University Press, 2014.

Raj, Selva J. "The Ganges, the Jordon, and the Mountain: The Three Strands of Santal Popular Catholicism." In Popular Christianity in India: Riting Between the Lines, edited by Selva J. Raj and Corinne G. Dempsey. Albany: State University of New York Press, 2002. 
Raj, Selva J. and Corinne G. Dempsey. "Introduction: Between, Behind, and Beyond the Lines." In Popular Christianity in India: Riting Between the Lines, edited by Selva J. Raj and Corinne G. Dempsey. Albany: State University of New York Press, 2002.

Raj, Selva J. and Corinne G. Dempsey, eds. Popular Christianity in India: Riting Between the Lines. Albany: State University of New York Press, 2002.

Rajamanickam, S. Roberto de Nobili on Adaptation. Palayamkottai: De Nobili Research Institute, 1971.

Ramabai, Pandita. A Testimony. Maharashtra: Kedgaon, 1917.

Raychaudhuri, Tapan. Europe Reconsidered: Perceptions of the West in NineteenthCentury Bengal. Delhi: Oxford University Press, 1988.

San Chirico, Kerry P.C. "Between Christian and Hindu: Khrist Bhaktas, Catholics and the Negotiations of Devotion in the Banaras Region." In Constructing Indian Christianities: Culture, Conversion and Caste, edited by Chad M. Bauman and Richard Fox Young. New Delhi: Routledge, 2014.

Schelling, Andrew, ed. The Oxford Anthology of Bhakti Literature. New Delhi: Oxford University Press, 2011.

Schomer, Karine. Mahadevi Varma and the Chhayavad Age of Modern Hindi Poetry. Berkeley: University of California Press, 1983.

Schomer, Karine and W.H. McLeod, eds. The Sant Tradition of India. Berkeley: Graduate Theological Union, 1987.

Scott, David S. "Hindu and Christian Bhakti: A Common Human Response to the Sacred." Indian Journal of Theology 29, no. 1 (January-March 1980): 12-32.

Shackle, Christopher and Rupert Snell. Hindi and Urdu since 1800: A Common Reader. New Delhi: Heritage Publishers, 1990.

Shukla, Ramchandra. Hindī Sāhity kā Itihās [History of Hindi Literature]. Delhi: Malik and Company, 2007 [1965].

Singh, Suraj Bhan. Hindī Bhāṣā: Sandarbh aur Samracanā [Hindi Language: Context and Structure]. Delhi: Sahitya Sahkar, 1997.

Sinha, Yunus Satyendra, trans. Masīh $\bar{\imath}$ A caran [The Christian Character, by Stephen Neill]. Jabalpur: Hindi Theological Literature Committee, 2008 [1956].

Thiel-Horstmann, Monika, ed. Bhakti in Current Research, 1972-1982. Berlin: Dietrich Reimer Verlag, 1983.

Thomas, Madathilparampil Mammen. "Introduction." In Robin H.S. Boyd, An Introduction to Indian Christian Theology. Madras: The Christian Literature Society, 1975 [1969].

Tiwari, Uday Narayan. Hindī Bhāṣā kā Udgam aur Vikās [The Birth and Growth of Hindi Language]. Allahabad: Lokbharit Prakashan, 2009.

Truschke, Audrey. Culture of Encounters: Sanskrit at the Mughal Court. New York: Columbia University Press, 2016.

Van der Veer, Peter. Religious Nationalism: Hindus and Muslims in India. Berkeley: University of California Press, 1994.

Young, Richard Fox, ed. India and the Indianness of Christianity: Essays on Understanding - Historical, Theological, and Bibliographical - in Honor of Robert Eric Frykenberg. Grand Rapids: William B. Eerdmans, 2009.

Amaladoss, Michael. The Asian Jesus. Maryknoll: Orbis Books, 2006.

Anand, John Henry. Śubh Śukravār kī Ārādhănā: Prabhu Yeśu ke Antim Sāt Śabd tatha Pahārī Upadeś [Liturgy of Good Friday: The Final Seven Words and the 
Sermon on the Mount of Christ Jesus]. Delhi: Indian Society for Promoting Christian Knowledge, 1993.

Anand, John Henry. O Mrtyu! Kahām Hai Terā Daimk? [O Death! Where is Thy Sting?]. Lucknow: Lucknow Publishing House, 1994.

Aquil, Raziuddin. The Muslim Question: Understanding Islam and Indian History. Gurgaon: Penguin Books, 2017 [2009].

Ārādhănā ke Gìt [Songs of Worship]. Lucknow: Lucknow Publishing House, 2009 [1975].

Arya, Sarojini V. Kavitā mem Śubh Samdeś [Good News in Poetry]. Delhi: Indian Society for Promoting Christian Knowledge, 2003.

Chadwick, Henry. The Early Church, revised edition. London: Penguin Books, 1993 [1967].

Chauhan, B.P. Singh. Viśvās Chațtān [Ground of Faith]. Delhi: M.S.S, 1962.

Chhungi, Hrangthan, ed. Theologizing Tribal Heritage: A Critical Re-look. Delhi: Indian Society for Promoting Christian Knowledge, 2008.

Collected Works of Mahatma Gandhi. Edited by the Indian Ministry of Information and Broadcasting. New Delhi: Publications Division, Government of India, 1958.

Dayal, Din. Masīhī Dharm Vijūān kà Paricay [An Introduction to Indian Christian Theology]. Jabalpur: Hindi Theological Literature Committee, 2005.

D’Mello, Edward. İ́svānī kā Sāthī [Companion of God's Voice]. Pune: Ishvani Kendra, 2007.

Dongre, Pushpa. Prem İśvarīy [Divine Love]. Lucknow: Lucknow Publishing House, 1960.

Doniger, Wendy. The Hindus: An Alternative History. New York: Penguin Books, 2009.

Eaton, Richard M. "Sufi Folk Literature and the Expansion of Indian Islam." History of Religions 14, no. 2 (1974): 117-127.

Fernando, Leonard and G. Gisspert-Sauch. Christianity in India: Two Thousand Years of Faith. Gurgaon: Penguin, Viking, 2004.

Frei, Hans W. The Identity of Jesus Christ: The Hermeneutic Bases of Dogmatic Theology. Eugene: Wipf \& Stock Publishers, 1997 [1974].

Frykenberg, Robert Eric. Christianity in India: From Beginning to the Present. New York: Oxford University Press, 2008.

Guha, Ramachandra. India After Gandhi: The History of the World's Largest Democracy. New York: Harper Perennial, 2008.

Hardy, Edward Rochie, ed. Christology of the Later Fathers. Louisville: Westminster John Knox Press, 1954.

Keay, F.E. A History of Hindī Literature. Calcutta: Association Press, 1920.

Khan, Benjamin. Māno Yā Na Māno Prabhu Yìśu Ko Jāno: Prabhu Yīśu Masīh kī Jindagī kì Kahānī [Believe or not, Know Jesus Christ: The Story of the Life of Jesus Christ]. Delhi: Indian Society for Promoting Christian Knowledge, 2003.

Khan, Benjamin. Khristīy Nìtiśāstr [Christian Ethics]. Jabalpur: Hindi Theological Literature Committee, 2009 [1981].

Khan, Jordan C. Sacchī Śanti kī Khoj [Search for True Peace]. Delhi: M.S.S., 1971.

Lall, Moti. Susamācār-Pracār Darśan aur Vyaktigat Pracār-Kary [Personal Evangelism]. Jabalpur: Hindi Theological Literature Committee, 2008 [1970].

Liddell, H.G. and R. Scott. An Intermediate Greek-English Lexicon, founded upon the seventh edition of Liddell and Scott's Greek-English Lexicon. Oxford: Oxford University Press, 1889. 
Mahendra, Shivraj K. Masīh Merī Manzil (“Christ my Destination”). Delhi: Indian Society for Promoting Christian Knowledge, 2008.

Masih, Komal and Christopher Peter. Prabhu Yeśu kī Jìvanī aur Sevākāry [The Life and Ministry of Jesus]. Jabalpur: Hindi Theological Literature Committee, 2007.

McGregor, Ronald S. "The Rise of Standard Hindi and Early Hindi Prose Fiction." Journal of the Royal Asiatic Society of Great Britain and Ireland, no. 3/4 (October 1967): 114-132.

McGregor, Ronald S., ed. The Oxford Hindi-English Dictionary. New Delhi: Oxford University Press, 1993.

Naim, Choudhri Mohammed. Introductory Urdu, Volume I, revised, third edition. Chicago: University of Chicago, 1999.

Nehru, Jawaharlal. The Unity of India: Collected Writings 1937-1940. New York: The John Day Company, 1942.

Orsini, Francesca. "Introduction." In Before the Divide: Hindi and Urdu Literary Culture, edited by Francesca Orsini. New Delhi: Orient BlackSwan Private Limited, 2010.

Prasad, S.W. Krūs kā Bhed: Krūs se Sāt Vacanoì par Ādhārit Laghu Pustikā [Mystery of the Cross: A Short Book Based on the Seven Sayings from the Cross]. Lucknow: Lucknow Publishing House, 1991.

Premkumar, R. Daniel. "The Commonwealth of Dalits and Tribals: Towards the Re-Positioning of the Church's Ecumenical Agenda in India Today." In Ecumenism: Prospects and Challenges, edited by Vinod Victor. Delhi: Indian Society for Promoting Christian Knowledge, 2001.

Shackle, Christopher and Rupert Snell. Hindi and Urdu since 1800: A Common Reader. New Delhi: Heritage Publishers, 1990.

Singh, C.K. Paul. Masīhī Ādbyātmik Śikșā [Christian Doctrines]. Ranchi: The Department of Evangelism and Literature, Gossner Evangelical Church, 1975.

Sona, Udit. Antim Sāt Vacan: Yīśu Dvārā Kahe Gaye Antim Vacanoì par Manan [Final Seven Sayings: Reflection on the Final Seven Sayings by Jesus]. Delhi: Indian Society for Promoting Christian Knowledge, 2010.

Sugirtharajah, Rasiah S., ed. Asian Faces of Jesus. Maryknoll: Orbis Books, 1993.

Thapar, Romila. Reading History from Inscriptions. Kolkata: K. P. Bagchi \& Company, 2002.

Thapar, Romila. The Penguin History of Early India: From the Origins to AD 1300. Gurgaon: Penguin Books, 2015 [2002].

Thiemann, Ronald F. Revelation and Theology: The Gospel as Narrated Promise. Eugene: Wipf \& Stock, 1985.

Yesudas, G.D. Krpāa Mārg [The Way of Grace]. Bombay: The Christian Literature Society, 1965.

Zahir, Alfred. Svarg aur Uske Uparānt [Heaven and Beyond]. Allahabad: N.I.C.T.B.S., 1968.

Abbott-Smith, G. A Manual Greek Lexicon of the New Testament. New York: T \& T Clark, 2001 [1921].

Aland, Barbara, Kurt Aland, Johannes Karavidopoulos, Carlo M. Martini, and Bruce M. Metzger, eds. Novum Testamentum Graece. Stuttgart: Deutsche Bibelgesellschaft, 1993 [1898].

Allen, Michael S. The Ocean of Inquiry: A Neglected Classic of Late Advaita Vedānta. Doctoral dissertation, Harvard University, 2013.

Amaladoss, Michael. The Asian Jesus. Maryknoll: Orbis Books, 2006. 
Anand, John Henry. Pāścāty Vidvānom kā Hindī Sāhity ["Western Contribution to the Hindi Language and Literature"]. Jabalpur: Hindi Theological Literature Committee, 2011 edition.

Anand, John Henry and Ramdutt Vashisht. 1988. Merā Parosī Merā Bhā̄i $[\mathrm{My}$ Neighbor My Brother]. Delhi: Indian Society for Promoting Christian Knowledge. Anand, John Henry and S.K. Warne, trans. Sampreșan: Arth aur Abhyās [Communication: Meaning and Practice]. Jabalpur: Hindi Theological Literature Committee, 1995.

Anderson, Walter K. and Sridhar Damle. The Brotherhood in Saffron: The RSS and Hindu Revivalism. Delhi: Vistaar Publications, 1987.

Appasamy, A.J. The Theology of Hindu Bhakti. Bangalore: Christian Literature Society, 1970.

Ārādhănā ke Gìt [Songs of Worship]. Lucknow: Lucknow Publishing House, 2009 [1975].

Arya, Sarojini V. Kavitā mem Śubh Saṃdeś [Good News in Poetry]. Delhi: Indian Society for Promoting Christian Knowledge, 2003.

Augustine, M.L. Fort William: Calcutta's Crowning Glory. New Delhi: Ocean Books, 1999.

Bahri, Hardev. Rājpāl Hindī Śabdakoś [Rajpal Hindi Dictionary]. Delhi: Rajpal \& Sons, 2010.

Boyd, Robin H.S. An Introduction to Indian Christian Theology. Madras: The Christian Literature Society, 1975 [1969].

Bulcke, Camille. Aṁgrezī-Hindī Koś, An English-Hindi Dictionary. Ranchi: Catholic Press, 2007 [1968].

Carey, Eustace. Memoir of William Carey. London: Jackson and Walford, 1836.

Carey, William. 'Journal.' Regent's Park College, Oxford: Angus Library and Archive, 1795.

Chakkarai, Vengal. Jesus the Avătār. Madras: Christian Literature Society, 1926.

Clarke, Sathianathan. Dalits and Christianity: Subaltern Religion and Liberation Theology in India. New Delhi: Oxford University Press, 1998.

Das, Sisir Kumar. Sabibs and Munshis: An Account of the College of Fort William. New Delhi: Orion Publications, 1978.

Dayal, Din. Uttar Bhārat aur Pākistān meì Masīhī Dharm: Pratham Śatābdī se Bīsvìm Śatābdì ke Ārambb Tak [The History of Christian Religion in North India and Pakistan: From the First Century to the Beginning of the Twentieth Century]. Jabalpur: Hindi Theological Literature Committee, 1997.

Dayal, Din. Masīhī Dharm Vijñān kā Paricay [An Introduction to Indian Christian Theology]. Jabalpur: Hindi Theological Literature Committee, 2005.

Dharmpustak kā Antbhāg, arthāt Mattī au Mārk au Lūk au Yohan Racit Prabhu Yīśu Khrīṣt kā Susamācār, aur Preritom kī Kriyāom kā Brittānt, aur Dharmopdeś aur Bhaviṣydvāky kī Patriyām, jo Yūnānī Bhāsāa se Hindī mem kiye gaye haim [or, The New Testament in Hindi]. Boston: Massachusetts Bible Society, 1909.

Doniger, Wendy. The Hindus: An Alternative History. New York: Penguin Books, 2009.

Duff, Alexander. India and India Missions: Including Sketches of the Gigantic System of Hinduism, both in Theory and Practice; also, Notices of Some of the Principal Agencies Employed in Conducting the Process of Indian Evangelization. Edinburgh: John Johnstone, 1839.

Eaton, Richard M. "Sufi Folk Literature and the Expansion of Indian Islam." History of Religions 14, no. 2 (1974): 117-127. 
England, John C., Jose Kuttianimattathil, John Mansford Prior, Lily A. Quintos, David Suh Kwang-sun, and Janice Wickeri, eds. Asian Christian Theologies: A Research Guide to Authors, Movements, Sources. Volume 1: Asia Region 7th20th Centuries; South Asia; Austral Asia. Delhi: Indian Society for Promoting Christian Knowledge, 2002.

Evangelical Lutheran Worship. Minneapolis: Augsburg Fortress, 2006.

Greaves, Edwin and N.K. Mukerji, eds. A Descriptive and Classified Catalogue of Hindi Christian Literature: Published Up To 1916-17. Allahabad: North India Christian Tract and Book Society, 1917.

Guha, Ramachandra. India After Gandhi: The History of the World's Largest Democracy. New York: Harper Perennial, 2008.

Heiler, Friedrich. The Gospel of Sädhu Sundar Singh (trans. Olive Wyon). Delhi: Indian Society for Promoting Christian Knowledge, 2009 [1924].

Hind̄̄ Bāibil: Purānā aur Nayā Niyam [Hindi Bible: Old and New Testament]. Bangalore: Bible Society of India, 1988-89.

Howell, Richard. Parivartan: Masīh se Milāp [Conversion: A Meeting with Christ]. New Delhi: Evangelical Fellowship of India, 2006.

Hutton, J.H. Census of India, 1931. Vol. I - India. Part I - Report. Delhi: Manager of Publications, 1933.

Ingleby, J.C. Missionaries, Education and India: Issues in Protestant Missionary Education in the Long Nineteenth Century. Delhi: Indian Society for Promoting Christian Knowledge, 2000.

Khilnani, Sunil. The Idea of India. New York: Farrar, Straus and Girous, 1999.

Kim, Sebastian C.H. In Search of Identity: Debates on Religious Conversion in India. New York: Oxford University Press, 2003.

King, Christopher R. One Language, Two Scripts: The Hindi Movement in Nineteenth Century North India. Delhi: Oxford University Press, 1994.

Krupat, Arnold. "Postcolonialism, Ideology, and Native American Literature." In The Post- Colonial Studies Reader, edited by Bill Ashcroft, Gareth Griffiths, and Helen Tiffin. New York: Routledge, 2006 [1995].

Mahto, S. Hundred Years of Christian Missions in Chotanagpur since 1845. Ranchi: The Chotanagpur Christian Publishing House, 1971.

Mayhew, Arthur. Christianity and the Government of India: An Examination of the Christian Forces at Work in the Administration of India and of the Mutual Relations of the British Government and Christian Missions, 1600-1920. London: Faber \& Gwyer, 1929.

McGregor, Ronald S., ed. The Oxford Hindi-English Dictionary. New Delhi: Oxford University Press, 1993.

Moget, Francis. Vagabonds for God: A Story of the Catholic Church in Central India, 1846- 1907. Bangalore: S.F.S. Publications, 1990.

Mohammed, Ovey N. "Jesus and Krishna." In Asian Faces of Jesus, edited by R.S. Sugirtharajah. Maryknoll: Orbis Books, 1993.

Nandy, Ashis. Time Warps: Silent and Evasive Pasts in Indian Politics and Religion. New Brunswick: Rutgers University Press, 2002.

Pavitr Bāibil, arthāt Purānà aur Nayā Dharm Niyam [Holy Bible, i.e., the Old and New Religious Testaments]. Bangalore: Bible Society of India, 2004.

Pickett, Jarrell Waskom. Christian Mass Movements in India: A Study with Recommendations. New York: Abingdon Press, 1934. 
Pollock, Sheldon. The Language of the Gods in the World of Men: Sanskrit, Culture, and Power in Premodern India. Berkeley: University of California Press, 2006.

Riddle, Thomas E. The Vision and the Call: A Life of Sadhu Sundar Singh. Delhi: Indian Society for Promoting Christian Knowledge, 2004 [1997].

Ruark, Robert C. El Paso Herald Post, Wednesday, May 09. UNC Digital Archives, Folder 273: Scan 85, 1962.

Ruark, Robert C. Spokane Daily Chronicle, May 10. UNC Digital Archives, Folder 273: Scan 85, 1962.

Ruark, Robert C. Winona Daily News, Sunday, May 13. UNC Digital Archives, Folder 273: Scan 85, 1962.

Sahu, Dhirendra Kumar. The Church of North India: A Historical and Systematic Theological Inquiry into an Ecumenical Ecclesiology. Frankfurt: Peter Lang, 1994.

Sham Rao, D.P. Five Contemporary Gurus in the Shirdi (Sai Baba) Tradition: A Study of Shri Sai Baba of Shirdi, Shri Upasani Baba of Sakuri, Shri Sati Godavari Mata of Sakuri, Shri Meher Baba of Abmednagar, and Shri Satya Sai Baba of Puttaparthi. Madras: The Christian Literature Society, 1972.

Sharma, Raj Bahadur. Christian Missions in North India, 1813-1913: A Case Study of Meerut Division and Dehra Dun District. Delhi: Mittal Publications, 1988.

Sheth, Noel. "Hindu Avatara and Christian Incarnation: A Comparison." Philosophy East and West 52, no. 1 (2002): 98-125.

Shukla, Ramchandra. Hindī Sāhity kā Itihās [History of Hindi Literature]. Delhi: Malik and Company, 2007 [1965].

Singh, Sundar. Wisdom of the Sadhu: Teachings of Sundar Singh, edited and compiled by Kim Comer. Walden: Plough Publishing House, 2000.

Sinha, Yunus Satyendra, trans. Masīhi Ā caran [The Christian Character, by Stephen Neill]. Jabalpur: Hindi Theological Literature Committee, 2008 [1956].

Stewart, Tony K. "In Search of Equivalence: Conceiving Muslim-Hindu Encounter Through Translation Theory." History of Religions 40, no. 3 (February 2001): 260-287.

Tete, Peter, ed. Constant Lievens and the History of the Catholic Church in Chotanagpur. Ranchi: Archbishop's House, 1993.

Thangaraj, M. Thomas. The Crucified Guru: An Experiment in Cross-Cultural Christology. Nashville: Abingdon Press, 1994.

Tsoukalas, Steven. Krșna and Christ: Body-Divine Relation in the Thought of Śànkara, Rāmānuja and Classical Christian Orthodoxy. Milton Keynes: Paternoster, 2006.

Varshney, Ashutosh. Ethnic Conflict and Civic Life: Hindus and Muslims in India. Delhi: Oxford University Press, 2002.

Varshney, Ashutosh. Battles Half Won: India's Improbable Democracy. New York: Penguin, 2014.

Vivekananda. The Complete Works of Swami Vivekananda. Almore, 1931.

Webster, John C.B. The Dalit Christians: A History. Delhi: Indian Society for Promoting Christian Knowledge, 2009 [1992].

Whitehead, Clive. Colonial Educators: The British Indian and Colonial Education Service, 1858-1983. London: I. B. Tauris, 2003.

Yale Digital Library Collection, digcoll 183956.

Yale Digital Library Collection, digcoll 184118. 
Anand, John Henry. Sampreșan tathā Mukti kā Śubh Sandeś [How to Communicate Good News]. Lucknow: Lucknow Publishing House, 1994.

Anand, John Henry and Ramdutt Vashisht. 1988. Merā Parosī Merā Bhā̄ [My Neighbor My Brother]. Delhi: Indian Society for Promoting Christian Knowledge.

Anand, John Henry and S.K. Warne, trans. Sampreșan: Arth aur Abhyās [Communication: Meaning and Practice]. Jabalpur: Hindi Theological Literature Committee, 1995.

Anderson, Walter K. and Sridhar Damle. The Brotherhood in Saffron: The RSS and Hindu Revivalism. Delhi: Vistaar Publications, 1987.

Asad, Talal. Genealogies of Religion: Discipline and Reasons of Power in Christianity and Islam. Baltimore: The John Hopkins University Press, 1993.

Babb, Lawrence A. and Susan S. Wadley, eds. Media and the Transformation of Religion in South Asia. Philadelphia: University of Pennsylvania Press, 1995.

Barclay, William. Through the Year with William Barclay, Devotional Readings for Every Day, ed. Denis Duncan. London: Hodder and Stoughton1977 [1971].

Barclay, William. Viliyam Bārkle ke Säth Dainik Masīhi Ācaran [Through the Year with William Barclay, Devotional Readings for Every Day], trans. C.W. David. Jabalpur: Hindi Theological Literature Committee, 2010.

Bhajan, Sam V. and Benjamin Khan. Isläm: Ek Paricay [Islam: An Introduction]. Jabalpur: Hindi Theological Literature Committee, 2004 [1974].

Bonhoeffer, Dietrich. The Cost of Discipleship. New York: Touchstone, 1995 [1937].

Dayal, Din. Uttar Bhārat aur Pākistān meín Masīhī Dharm: Pratham Śatābdī se Bīsvìm Śatābdi ke Ārambh Tak [The History of Christian Religion in North India and Pakistan: From the First Century to the Beginning of the Twentieth Century]. Jabalpur: Hindi Theological Literature Committee, 1997.

Dayal, Din. Vyaktigat Manan-Cintan [Personal Reflection]. Jabalpur: Hindi Theological Literature Committee, 2007.

Engineer, Asghar Ali, ed. Babri-Masjid Ramjanambhoomi Controversy. Delhi: Ajanta Publications (India), 1990.

Gill, S.S. "Why Ramayan on Doordarshan." The Indian Express, August 8, 1988: 8-9. Howell, Richard. Parivartan: Masīh se Milāp [Conversion: A Meeting with Christ]. New Delhi: Evangelical Fellowship of India, 2006.

James, Elizabeth E., et al. Mahilā Dharmavijñān Pāthya-Pustak [Women's Theological Text Book]. Jabalpur: Hindi Theological Literature Committee, 2010 [1978].

Jonathan, Franklin C. Biśap: Dāyitv, Darśan aur Mūly [Bishop: Vocation, Vision and Value]. Jabalpur: Hindi Theological Literature Committee, 1994.

Khan, Benjamin. Samvād: Kyom aur Kaise, Masīhī Driștikon Se [Dialogue: Why and How, from a Christian Perspective]. Jabalpur: Hindi Theological Literature Committee, 1994.

Khan, Yasmin. The Great Partition: The Making of India and Pakistan. New Haven: Yale University Press, 2007.

King, Robert D. Nehru and the Language Politics of India. Delhi: Oxford University Press, 1998.

Lall, Moti. Susamācār-Pracār Darśan aur Vyaktigat Pracār-Kary [Personal Evangelism]. Jabalpur: Hindi Theological Literature Committee, 2008 [1970].

Mankekar, Purnima. "National Texts and Gendered Lives: An Ethnography of Television Viewers in a North Indian City." American Ethnologist 20, no. 3 (1993): 543-564. 
Mankekar, Purnima. Screening Culture, Viewing Politics: An Ethnography of Television, Womanhood, and Nation in Postcolonial India. Durham: Duke University Press, 1999.

Mankekar, Purnima. "Epic Contests: Television and Religious Identity in India.” In Media Worlds: Anthropology on New Terrain, edited by Faye D. Ginsburg, Lila Abu-Lughod, and Brian Larkin. Berkeley: University of California Press, 2002.

Metaxas, Eric. Bonhoeffer: Pastor, Martyr, Prophet, Spy, A Righteous Gentile vs. the Third Reich. Nashville: Thomas Nelson, 2010.

Patlia, Daniel. Pāstarī Viddhyā [Pastoral Knowledge]. Jabalpur: Hindi Theological Literature Committee, 2008 [1968].

Paul, Winifred Irene. Striyom kā Parameśvar ke Sāth Calnā [Walking of Women with God]. Delhi: Indian Society for Promoting Christian Knowledge, 2008.

Pintchman, Tracy, ed. Women's Lives, Women's Rituals in the Hindu Tradition. New York: Oxford University Press, 2007.

Pollock, Sheldon. "Ramayana and Political Imagination in India." Journal of Asian Studies 52, no. 2 (1993): 261-297.

Rajagopal, Arvind. "Ram Janmbhoomi, Consumer Identity and Image-Based Politics." Economic and Political Weekly (July 2, 1994): 1659-1668.

Rajagopal, Arvind. Politics after Television: Religious Nationalism and the Reshaping of the Indian Public. Cambridge: Cambridge University Press, 2001.

Scharf, Peter. Rāmopākhyāna - the Story of Rāma in the Mahābhārata, And Independent-Study Reader in Sanskrit. New York: RoutledgeCurzon, 2003.

Schüssler Fiorenza, Elisabeth. Discipleship of Equals: A Critical Feminist Ekklēsiology of Liberation. New York: Crossroad, 1993.

Schüssler Fiorenza, Elisabeth. Jesus and the Politics of Interpretation. New York: Continuum, 2000.

Sinha, Yunus Satyendra, trans. Masīh $\bar{\imath}$ Ācaran [The Christian Character, by Stephen Neill]. Jabalpur: Hindi Theological Literature Committee, 2008 [1956].

Thapar, Romila. “The Ramayana Syndrome.” Seminar, no. 353, January 1989.

The Hindu Speaks. The Hindu Speaks on Religious Values. Chennai: Kasturi \& Sons Ltd., 1999.

Union of Catholic Asian News. "Bible series taken off national television after alleged Muslim Threats.” March 31, 1993.

Varshney, Ashutosh. "Contested Meanings: India's National Identity, Hindu Nationalism, and the Politics of Anxiety." Daedalus 122, no. 3 (1993): 227-261.

Bahri, Hardev. Rājpāl Hindī Śabdakoś [Rajpal Hindi Dictionary]. Delhi: Rajpal \& Sons, 2010.

Balagangadhara, S.N. Reconceptualizing India Studies. New Delhi: Oxford University Press, 2012.

Bhajan, Sam V. and Benjamin Khan. Islām: Ek Paricay [Islam: An Introduction]. Jabalpur: Hindi Theological Literature Committee, 2004 [1974].

Bonhoeffer, Dietrich. Life Together: The Classic Exploration of Christian Community. New York: HarperOne, 1954 [1938].

Bonhoeffer, Dietrich. Ethics. New York: Touchstone, 1995 [1949].

Bonhoeffer, Dietrich. Letters and Papers from Prison. New York: Touchstone, 1997 [1951].

Bulcke, Camille. Amingrezī-Hindī Koś, An English-Hindi Dictionary. Ranchi: Catholic Press, 2007 [1968]. 
Dayal, Din. Uttar Bhārat aur Pākistān meì Masīhī Dharm: Pratham Śatābdī se Bīsvìm Śatābdì ke Ārambh Tak [The History of Christian Religion in North India and Pakistan: From the First Century to the Beginning of the Twentieth Century]. Jabalpur: Hindi Theological Literature Committee, 1997.

Engineer, Asghar Ali, ed. Babri-Masjid Ramjanambhoomi Controversy. Delhi: Ajanta Publications (India), 1990.

Flood, Gavin. An Introduction to Hinduism. Cambridge: University of Cambridge Press, 1996.

Howell, Richard. Parivartan: Masīh se Milāp [Conversion: A Meeting with Christ]. New Delhi: Evangelical Fellowship of India, 2006.

Khan, Benjamin. The Concept of Dharma in Valmiki Ramayana. Delhi: Munshi Ram Manohar Lal, 1965.

Khan, Benjamin. Khristīy Nìtiśāstr [Christian Ethics]. Jabalpur: Hindi Theological Literature Committee, 2009 [1981].

Khan, Benjamin. Bìsvìim Śatābdī ke Pramukh Dharmavijũānī [Major Christian Theologians of the Twentieth Century]. Jabalpur: Hindi Theological Literature Committee, 1990.

Khan, Benjamin. Samvād: Kyom aur Kaise, Masīhī Driștikon Se [Dialogue: Why and How, from a Christian Perspective]. Jabalpur: Hindi Theological Literature Committee, 1994.

Lossky, Nicholas, José Míguez Bonino, John Pobee, Tom F. Stransky, Geoffrey Wainwright, and Pauline Webb, eds. Dictionary of the Ecumenical Movement. Geneva: World Council of Churches Publications, 2002.

McGregor, Ronald S., ed. The Oxford Hindi-English Dictionary. New Delhi: Oxford University Press, 1993.

Metaxas, Eric. Bonhoeffer: Pastor, Martyr, Prophet, Spy, A Righteous Gentile vs. the Third Reich. Nashville: Thomas Nelson, 2010.

Robinson, Bob. Christians Meeting Hindus: An Analysis and Theological Critique of the Hindu-Christian Encounter in India. Milton Keynes: Regnum Books International, 2004.

Scharf, Peter. Rāmopākbyāna - the Story of Rāma in the Mahābhārata, And IndependentStudy Reader in Sanskrit. New York: RoutledgeCurzon, 2003.

Altman, Michael J. Heathen, Hindoo, Hindu: American Representations of India, 1721-1893. New York: Oxford University Press, 2017.

Bauman, Chad M. Pentecostals, Proselytization, and Anti-Christian Violence in Contemporary India. New York: Oxford University Press, 2015.

Clooney, Francis X. Hindu God, Christian God: How Reason Helps Break Down the Boundaries Between Religions. New York: Oxford University Press, 2001.

Dalmia, Vasudha. The Nationalization of Hindu Traditions: Bhāratendu Hariśchandra and Nineteenth-Century Banaras. Ranikhet: Permanent Black, 2010 [1997].

D’Sa, Francis X. "Christian Incarnation and Hindu Avatara.” Concilium 2 (1993): $77-85$.

Duff, Alexander. India and India Missions: Including Sketches of the Gigantic System of Hinduism, both in Theory and Practice; also, Notices of Some of the Principal Agencies Employed in Conducting the Process of Indian Evangelization. Edinburgh: John Johnstone, 1839.

Ganeri, Martin. "Catholic Encounter with Hindus in the Twentieth Century: In Search of an Indian Christianity.” New Blackfriars 88, no. 1016 (2007): 410-432. 
Harper, Susan Billington. In the Shadow of the Mahatma: Bishop V. S. Azariah and the Travails of Christianity in British India. Grand Rapids: William B. Eerdmans, 2000. Jain, Pankaj. "From Kil-Arni to Anthony: The Portrayal of Christians in Indian Films." Visual Anthropology 23, no. 1(2009): 13-19.

James, Elizabeth E., et al. Mahilā Dharmavijñān Pāthya-Pustak [Women's Theological Text Book]. Jabalpur: Hindi Theological Literature Committee, 2010 [1978].

Khan, Benjamin. Khristīy Nìtiśāstr [Christian Ethics]. Jabalpur: Hindi Theological Literature Committee, 2009 [1981].

Khan, Benjamin. Bìsvìim Śatābdī ke Pramukh Dharmavijũānī [Major Christian Theologians of the Twentieth Century]. Jabalpur: Hindi Theological Literature Committee, 1990.

King, Christopher R. One Language, Two Scripts: The Hindi Movement in Nineteenth Century North India. Delhi: Oxford University Press, 1994.

King, Robert D. Nehru and the Language Politics of India. Delhi: Oxford University Press, 1998.

Lalhmangaiha, Andrew. Holistic Mission and the Serampore Trio. Delhi: Indian Society for Promoting Christian Knowledge, 2010.

Larbeer, Mohan. "The Story of the Dalits of India.” In God, Christ \& God's People in Asia, edited by Dhyanchand Carr. Hong Kong: Christian Conference of Asia, 1995.

Mankekar, Purnima. "Epic Contests: Television and Religious Identity in India." In Media Worlds: Anthropology on New Terrain, edited by Faye D. Ginsburg, Lila Abu-Lughod, and Brian Larkin. Berkeley: University of California Press, 2002.

Manorama, Ruth. "Dalit Women: The Thrice Alienated." In Asian Expressions of Christian Commitment: A Reader in Asian Theology, edited by T. Dayanandan Francis and F.J. Balasundaram. Madras: The Christian Literature Society, 1992.

McGregor, Ronald S., ed. The Oxford Hindi-English Dictionary. New Delhi: Oxford University Press, 1993.

Melanchthon, Monica Jyotsna. “A Dalit Reading of Genesis 10-11:9.” In Scripture, Community, and Mission: Essays in Honor of D. Preman Niles, edited by Philip L. Wickeri. Hong Kong: Christian Conference of Asia, 2003.

Pandey, Gyanendra. The Construction of Communalism in Colonial North India, third edition. New Delhi: Oxford University Press, 2006 [1990].

Panikkar, Raimundo. The Unknown Christ of Hinduism: Towards an Ecumenical Christophany. Maryknoll: Orbis Books, 1981 [1964].

Pieris, Aloysius. "The Buddha and the Christ: Mediators of Liberation." In Asian Faces of Jesus, edited by R.S. Sugirtharajah. Maryknoll: Orbis Books, 1993.

Shiri, Godwin. The Plight of Christian Dalits - A South Indian Case Study. Bangalore: Asian Trading Corporation, 1997.

Sugirtharajah, Rasiah S. The Bible and the Third World: Precolonial, Colonial and Postcolonial Encounters. Cambridge: Cambridge University Press, 2001.

Van der Veer, Peter. Religious Nationalism: Hindus and Muslims in India. Berkeley: University of California Press, 1994.

Ward, William. A View of the History, Literature, and Religion of the Hindoos: Including a Minute Description of their Manners and Customs, and Translation from their Principal Works. Volume 1, third edition. London: Black, Parbury, and Allen, 1817.

Williams, Monier, ed. Original Papers Illustrating the History of the Application of the Roman Alphabet to the Languages of India. London: Longman, Brown, Green, Longmans, and Roberts, 1859. 
Yagi, Seiichi. "Christ and Buddha.” In Asian Faces of Jesus, edited by R.S. Sugirtharajah. Maryknoll: Orbis Books, 1993.

Yelle, Robert A. The Language of Disenchantment: Protestant Literalism and Colonial Discourse in British India. New York: Oxford University Press, 2013. 